\title{
Myelin pathology in ataxia-telangiectasia is the cell-intrinsic consequence of ATM deficiency in the oligodendrocytes
}

\author{
Kai-Hei Tse , 2*\# $^{2 *}$ \\ Aifang Cheng $2,3^{*}$ \\ Sunny Hoi-Sang Yeung ${ }^{1}$ \\ Gerald Wai-Yeung Cheng ${ }^{1}$ \\ Qingyang Wang ${ }^{2}$ \\ Beika Zhu ${ }^{2}$ \\ Yong $\mathrm{Cui}^{4}$ \\ Liwen Jiang ${ }^{4}$ \\ Julia Kofler ${ }^{5}$ \\ Karl Herrup ${ }^{2,6, \#}$
}

${ }^{1}$ Department of Health Technology and Informatics, The Hong Kong Polytechnic University, Hong Kong S.A.R, China

${ }^{2}$ Department of Ocean Science, The Hong Kong University of Science and Technology, Hong Kong S.A.R, China

${ }^{3}$ Division of Life Science, The Hong Kong University of Science and Technology, Hong Kong S.A.R, China

${ }^{4}$ School of Life Sciences, Centre for Cell \& Developmental Biology and State Key Laboratory of Agrobiotechnology, The Chinese University of Hong Kong, Hong Kong S.A.R, China

${ }^{5}$ Division of Neuropathology, School of Medicine

University of Pittsburgh, PA, United States

${ }^{6}$ Department of Neurobiology

University of Pittsburgh, PA, United States

* The author contributes equally

\# To whom correspondence should be addressed to

TSE KH email: kh-franki.tse@polyu.edu.hk and HERRUP K email: herrup@pitt.edu 
medRxiv preprint doi: https://doi.org/10.1101/2021.01.22.20245217; this version posted January 26, 2021. The copyright holder for this preprint (which was not certified by peer review) is the author/funder, who has granted medRxiv a license to display the preprint in All rights reserved. No perpetuity.

Tse et al

medRxiv

\section{ABSTRACT}

Ataxia-telangiectasia (A-T) is a rare genetic disease caused by mutations in the gene encoding the ATM (Ataxia-telangiectasia mutated) protein. Although neuronal degeneration in the cerebellum remains the most prominent sign in A-T, neuroimaging studies reveal myelin abnormalities as early comorbidities. We hypothesize that these myelin defects are the direct consequence of ATM deficiencies in the oligodendrocytes (OL) lineage. We examined samples from ten A-T brains in which the ATM mutations had been mapped by targeted genomic sequencing as well as samples from $\mathrm{Atm}^{-/-}$mice. In healthy human and wild type mouse cerebellum we confirmed the presence of ATM in white matter OLs. In A-T but not agematched controls, a significant reduction in OL density was coupled with a massive astrogliosis. We found that the extent of this OL pathology was particularly strong in cases with frameshifts or premature termination ATM mutations. Similar pathologies were also found in $\mathrm{Atm}^{-/-}$mice in an age- and gene dose-dependent fashion. In vitro, DNA damage induced by etoposideinduced DSBs or blockade of ATM activity with KU-60019 differentially jeopardized cell cycle control in OL progenitors and mature OLs. Turning to structural analysis in silico, we identified likely interactions between ATM and myelin basic protein as well as myelin regulatory factor and confirm this by immunoprecipitation. These novel OL-specific functions of the ATM protein affect all stages of the OL lineage. They thus provide a cell biological basis for a direct role for ATM in central nervous system myelination and illustrate how the myelin pathology found in A-T is at least in part independent of neuronal degeneration.

\section{KEYWORDS}

Ataxia-Telangiectasia; ATM; DNA double strand breaks; myelin; oligodendrocyte 
medRxiv preprint doi: https://doi.org/10.1101/2021.01.22.20245217; this version posted January 26, 2021. The copyright holder for this

preprint (which was not certified by peer review) is the author/funder, who has granted medRxiv a license to display the preprint in perpetuity.

Tse et al

All rights reserved. No reuse allowed without permission.

medRxiv

\section{INTRODUCTION}

Ataxia-telangiectasia (A-T) is a rare genetic disease that affects $1: 88,000$ to $1: 400,000$ newborns [1-3]. All known cases of A-T are caused by mutations of the gene encoding the ATM protein (Ataxia-telangiectasia mutated), a member of the phosphatidylinositol-3-kinase (PI3K) family that is expressed by all cell types. ATM is best known for its role in coordinating the responses of dozens of proteins needed for the repair of DNA double strand breaks (DSBs) [4]. After a DSB is formed, a specialized protein complex, MRN (Mre11-Rad50-Nbs1), assembles at the breakage site and serves as a docking site for ATM. Though normally found as a relatively inactive dimer, once it has docked on the MRN complex ATM autophosphorylates on serine 1981 (human sequence numbering) and dissociates into two active monomers. The downstream phosphorylation targets of the ATM kinase regulate DNA repair, cell cycle progression and cell death [5]. While its roles in the DDR (DNA damage response) are carried out in the cell nucleus, ATM serves other functions in the cytoplasm, many of which are independent of its specific role in genomic repair [6]. Outside the nucleus, ATM protein can be found in the cytoplasm [7] a range of cytoplasmic vesicles [8-11] and in mitochondria $[12,13]$. As suggested by its dual localization in nucleus and cytoplasm, ATM participates in a diversity of cellular functions that are independent of the DDR [14]. These include acting as a sensor against oxidative stress [15-20], as a partner with transcription factors to regulate inflammation [21-24] and as a regulator of synaptic vesicle trafficking in cortical neurons [25].

Children with A-T are clinically characterized first and foremost by a progressive cerebellar ataxia [3]. The ataxia is linked with cerebellar atrophy that is easily seen on magnetic resonance imaging (MRI). Histopathology reveals a massive loss of cerebellar mass associated with the loss of Purkinje and cerebellar granule cells as well as with the atrophy of myelinated tracts [26]. The myelin associated phenotype, though less commonly cited, appears in descriptions dating back to some of the earliest neuropathological studies of A-T where demyelination in the posterior column of the spinal cord [27-31] cerebellar folia, optic nerve, corpus callosum [27, 29, 31] and peripheral nerves [32] were reported. Indeed, white matter hyperintensities (periventricular leukodystrophy), suggestive of myelin abnormalities, are detectable in A-T patients as early as 17 months of age [33-35]. Using diffusion tensor imaging, Sahama et al found compromised myelinated tract integrity of corticomotor, corticospinal and somatosensory pathways in adolescent A-T subjects [26]. While the connections between neuronal pathology and ATM deficits have been carefully studied in experimental rodent models of A-T, the white matter (WM) abnormalities are less well documented, particularly in the early stages of the disease [36]. Since the clinical evidence suggests that myelin pathology can be found early in A-T disease progress, we wished to test the hypothesis that ATM deficits in the oligodendrocyte (OL) lineage directly cause such WM abnormalities.

The idea that the myelin abnormalities are early events in A-T disease pathogenesis is supported by the observation that ATM has important functions during early brain development. For example, ATM helps orchestrate neurogenesis [37, 38]. Further, three independent reports have shown that Atm-deficient stem cells fail to generate a normal number of OLs in vitro and in vivo [38-40]. Such failures of OLs differentiation during development are unlikely to be the consequences of a defective DDR. From this perspective, the early appearance of myelin pathology in A-T suggests that the defects are primary events, possibly of developmental origin, rather than a late, secondary consequence of the neuronal degeneration.

In this study, we not only confirm the cellular pathology of OL underlying myelin degeneration in human A-T cerebella, but we also provide experimental evidence for essential functions of ATM during the development and maturation of OLs in vivo and in vitro. By mapping the 
medRxiv preprint doi: https://doi.org/10.1101/2021.01.22.20245217; this version posted January 26, 2021. The copyright holder for this preprint (which was not certified by peer review) is the author/funder, who has granted medRxiv a license to display the preprint in All rights reserved. No reuse ally.

Tse et al

medRxiv

ATM mutations in these A-T cases, we find that frameshifts and premature ATM truncations in the region of the protein known as the spiral and pincer domains are associated with more cytological abnormalities in the OL population. In culture, ATM inhibition and activation confirm that ATM serves both endogenous regulatory functions and DDR-associated functions during cell cycle progression and differentiation in the OL lineage. By modeling the predicted protein structures of 14 clinical ATM mutant variants in silico, we evidence for direct proteinprotein interactions between ATM and myelin basic protein as well as myelin regulatory factor. Together, our findings demonstrate the existence of important, OL-specific functions of ATM , and highlight a neuron-independent role for ATM in the pathogenesis of A-T.

\section{MATERIALS AND METHODS}

\section{Materials}

All chemicals were purchased from Sigma-Aldrich if not otherwise specified. Cell culture media and supplements were obtained from Life Technologies and Invitrogen of ThermoFisher Scientific. All pharmacological inhibitors or compounds namely Camptothecin (\#1100), Etoposide (\#1226) and KU-60019 (\#4176) were obtained from Tocris Bioscience.

\section{Postmortem human cerebellar tissues}

Formalin fixed paraffin embedded postmortem cerebellar tissues of a normal aging group were kindly provided by Alzheimer's Disease Research Center (ADRC) Brain Bank at University of Pittsburgh with approvals from the Committee for Oversight of Research and Clinical Training Involving Decedents at University of Pittsburgh. All cases were characterized neuropathologically, and classified as normal by Braak staging, with no known cerebellar diseases. All cases were supplied as tissue sections on microscopic slides at a thickness of 10 $\mu \mathrm{m}$. Frozen postmortem cerebellar tissues from ten A-T cases, as well as ten age-matched normal controls (NC) were kindly provided by the NeuroBioBank of the National Institutes of Health at The University of Maryland with approvals from Tissue Access Committee at NeuroBioBank. All tissues were isolated from left cerebellar cortex that had been frozen without fixation and stored at $-80{ }^{\circ} \mathrm{C}$. Tissue samples were embedded in TissueTek O.C.T. medium, cryosectioned at $16 \mu \mathrm{m}$, mounted on glass slides and kept at $-80{ }^{\circ} \mathrm{C}$ until use. Before immunostaining the cryosections were fixed for $30 \mathrm{mins}$ in $4 \%$ paraformaldehyde at room temperature. These studies of postmortem tissues were approved by the Committee of Research Practices at The Hong Kong University of Science and Technology (HKUST) as well as Human Subjects Ethics Application Review board at The Hong Kong Polytechnic University (PolyU). The demography of all cases is listed in Table S1.

\section{Targeted genomic sequencing and analysis}

To prepare genomic libraries, DNA was extracted using the Qiagen DNeasy Blood \& Tissue Kit. After quantifications using Quant-iT ${ }^{\mathrm{TM}}$ PicoGreen ${ }^{\mathrm{TM}}$ dsDNA Assay Kit on a NanoDrop ${ }^{\mathrm{TM}}$ 3300 Fluorospectrometer (Thermo Fisher Scientific), the samples were tagmented, captured, amplified and processed for targeted genomic sequencing using TruSight ${ }^{\circledR}$ Inherited Disease Sequencing Panel [41]. The libraries were normalized, indexed, pooled and quality controlled using High Sensitivity NGS Analysis Kit (DNF-474, Advanced analytical) on Fragment Analyzer $^{\mathrm{TM}}$. The pooled libraries were sequenced on an Illumina Mid-Output Kit in NextSeq550 platform in The Biosciences Central Research Facility, HKUST. The raw reads were aligned against the human reference genome (hg19). The aligned reads in the targeted genome were analyzed for single nucleotide polymorphisms (SNPs) or InDels (insertions or deletions) based on Genome Analysis Toolkit (GATK, Broad Institute). The annotated genetic 
medRxiv preprint doi: https://doi.org/10.1101/2021.01.22.20245217; this version posted January 26, 2021. The copyright holder for this preprint (which was not certified by peer review) is the author/funder, who has granted medRxiv a license to display the preprint in All rights reserved. No reuse allowed without permission.

Tse et al

medRxiv

variants were called and analyzed by the panel-bundled software Illumina VariantStudio ${ }^{\mathrm{TM}}$ 3.0. The TruSight ${ }^{\circledR}$ Inherited Disease Sequencing Panel targets 550 genes known to cause rare inherited diseases. A total of $\sim 30,000$ probes spanning 8801 exons and exon-intron boundaries of these genes [41], including ATM and other DNA repair genes causing progeria syndromes, were included. The SNPs and their properties such as variant types, genotype (heter/homozygosity), coordinates, exon/intron, protein and cDNA consequences, and potential pathogenicity, were identified. All mutations found in the targeted region were matched against multiple SNP databases including ClinVar (NCBI), COSMIC (Sanger Institute), dbSNPs (NCBI) and HGVS (Human Genome Organization).

\section{Animals}

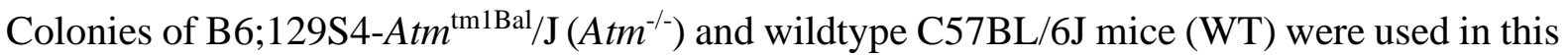
study (Jackson Laboratory, Bar Harbor, Maine). The Atm $^{-/-}$strain carries an engineered mutation in the mouse Atm gene which disrupts the exons encoding the kinase domain [42, 43]. At appropriate age, the animals were deep anesthetized by Avertin (1.25\% tribromoethanol, $375 \mathrm{mg} / \mathrm{kg}$, intraperitoneal), the chest cavity was surgically opened and transcardial perfusion with Phosphate buffer saline (PBS) was performed using a peristaltic pump. The animal was then dissected and its brain was isolated. The left hemisphere was frozen for protein and gene expression analysis, while the right hemisphere was fixed by immersion in paraformaldehyde (4\%) for 24 hours at $4{ }^{\circ} \mathrm{C}$. The tissue was then cryopreserved in PBS-sucrose (30\% w/v) for 48 hours, followed by embedding and cryosectioning at $10 \mu \mathrm{m}$ beginning at the midline. All sections were mounted on glass slides which were kept at $-80{ }^{\circ} \mathrm{C}$ until use.

All animals were housed in a temperature and humidity controlled environment on a 12 hour light/dark cycle with food and water ad libitum. All animals were maintained and cared for by the Animal and Plant Care Facility (APCF) at HKUST in compliance with Legislations and The Code of Practice for Care and Use of Animals for Experimental Purposes of Hong Kong. All animal experiments and analysis were approved by both the Animal Ethics Committee, of the Committee on Research Practices of HKUST and Animal Subjects Ethics Sub-Committee of PolyU. All procedures were also conducted with a license from the Department of Health, Government of Hong Kong.

\section{Primary oligodendrocyte culture}

Mice at postnatal day 2 (P2) to P6 mice were sacrificed by decapitation and brains dissected free of the skull [44-46]. The cerebellum and olfactory bulbs were removed while whole cerebrum was minced with fine scissors, followed by trypsin-based enzymatic digestion $\left(0.25 \%, 30 \mathrm{mins}, 37^{\circ} \mathrm{C}\right)$. After neutralization, the cell suspension was filtered through a cell strainer with a $40 \mu \mathrm{m}$ pore size. The suspension was then centrifuged (1500 rpm, $5 \mathrm{~min}$ ), the cell pellet was resuspended and the cells transferred to a dish coated with BSL1 (1:500, L1100, Vector Laboratories) for $15 \mathrm{~min}$ at room temperature to remove any isolectin B4+ microglia. The resulting suspension, consisting primarily of a mixture of OL and astrocytes, was collected, centrifuged and plated on poly-L-lysine coated culture dishes to expand the OL progenitor cell (OPC) population. OPC growth medium was composed of DMEM/F12 (Gibco), fetal bovine serum $(\mathrm{FBS}, 1 \% \mathrm{v} / \mathrm{v}$ ) and N2 supplement (bovine serum albumin [70 $\mu \mathrm{g} / \mathrm{mL}]$, insulin [5 $\mu \mathrm{g} / \mathrm{mL}$ ], human transferrin [5 $\mu \mathrm{g} / \mathrm{mL}]$, putrescine $[1.6 \mu \mathrm{g} / \mathrm{mL}]$, progesterone $[60 \mathrm{ng} / \mathrm{mL}$, sodium selenite [5 ng/mL] and L-thyroxine [400 ng/mL] - Sigma). Platelet derived growth factor-AA (PDGF, $10 \mathrm{ng} / \mathrm{mL}$, Sigma), NT3 (1 ng/mL, Peprotech) and CNTF (10 ng/mL, Peprotech) were added to stimulate OPC proliferation. To differentiate OPC into mature OLs, the expanded OPCs were harvested after 5 days in vitro and plated on coated $12 \mathrm{~mm}$ glass coverslips (35,000 cells each). The OPC were then induced to differentiate for 7-14 days using $34 \mathrm{ng} / \mathrm{mL}$ triiodothyronine (T3) in the absence of growth factors, and at reduced FBS $(0.1 \%)$ 
medRxiv preprint doi: https://doi.org/10.1101/2021.01.22.20245217; this version posted January $26,2021$. The copyright holder for this

preprint (which was not certified by peer review) is the author/funder, who has granted medRxiv a license to display the preprint in perpetuity.

Tse et al

All rights reserved. No reuse allowed without permission.

medRxiv

concentration. The DNA synthesis at the $\mathrm{S}$ phase was detected by Click-iT ${ }^{\mathrm{TM}}$ EdU Cell Proliferation Kit for Imaging according to manufacturer's instruction (ThermoFisher)

Oli-Neu cell culture and transfection

An OPC cell line, Oli-Neu, was kindly provided by Dr Jacqueline Trotter (University of Mainz, Germany). Oli-Neu cells retain an OPC phenotype but can differentiate into myelin-expressing OL upon db-cAMP stimulation $(1 \mathrm{mM})$ [47-49]. Oli-Neu cells were cultured in DMEM/F12 medium supplemented with $1 \%$ normal horse serum, $1 \% \mathrm{~N} 2$ supplement and $1 \%$ penicillinstreptomycin. For shRNA experiments, cells were plated on coated $13 \mathrm{~mm}$ glass coverslips (20,000-35,000 cells) in a 24 well plate. To introduce shRNA, cells were then transfected with a total of $0.5-1 \mu \mathrm{g}$ of DNA construct (GFP-Atm-shRNA (TL320267) or GFP-Atr-shRNA (TL519184) or a scrambled 29-mer control shRNA cassette in pGFP-C-shLenti vector (OriGene) using Lipofectamine 2000 reagents (Thermo Fisher Scientific). The transfected cells were examined under a fluorescent microscope 48 hours after transfection before proceeding with immunocytochemistry or gene expression experiments.

\section{Primary neuronal culture}

Primary cortical neurons were derived from wildtype mouse embryos, as reported earlier [25, 50]. Briefly, E16 embryos were isolated and the cerebral cortices were dissected after the meninges were removed. The cortices were then enzymatically dissociated in trypsin-EDTA $\left(1 \mathrm{X}, 0.25 \%\right.$, Gibco) for $12 \mathrm{~min}$ at $37^{\circ} \mathrm{C}$. After neutralization with $10 \%$ fetal bovine serum in DMEM, the cells were transferred to NeuroBasal medium containing B27 supplement (2\%), GlutaMAX (1\%) and penicillin-streptomycin $(1 \%, 10,000 \mathrm{U} / \mathrm{mL}$; all from Life Technologies). The tissue suspension was triturated through a $10 \mathrm{~mL}$ glass pipette 10 times before being allowed to settle by gravity in a $15 \mathrm{~mL}$ conical tube for 8 minutes. The supernatant containing dissociated cells was transferred to another conical tube for quantification. Neuronal cells were plated at a density of 8,500 cells $/ \mathrm{cm}^{2}$ on poly-L-lysine coated glass coverslips in 24 well plates for microscopy experiments. All cultures were kept at $37{ }^{\circ} \mathrm{C}$ in a humidified incubator with $5 \%$ $\mathrm{CO}_{2} / 95 \%$ air. Half of the medium was removed and replaced with fresh medium every two days up to DIV14.

\section{Immunohistochemistry and immunocytochemistry}

For immunohistochemistry of the human paraffin sections, slides were baked for 1 hour at 60 ${ }^{\circ} \mathrm{C}$ before being deparaffinized twice in xylene for $10 \mathrm{~min}$. After serial rehydration in 100, 95, 70 and 50\% ethanol, epitope retrieval was performed at $100{ }^{\circ} \mathrm{C}$ water bath in basic Tris-EDTA buffer (10 mM Tris Base, $1 \mathrm{mM}$ EDTA solution, 0.05\% Tween 20, pH 9.0) for $30 \mathrm{~min}$. Any residual peroxidase activity was quenched by incubation in $3 \% \mathrm{H}_{2} \mathrm{O}_{2}$ for $10 \mathrm{~min}$. The slides were blocked with normal goat or horse serum for $30 \mathrm{~min}$ before application of primary antibodies (anti-Olig2, 1:300, anti-ATM(2c1), 1:300) overnight a $4{ }^{\circ} \mathrm{C}$. All primary antibodies used for immunohistochemistry are listed in Table S2. After TBS waedshes, sections were incubated with the corresponding secondary antibody (VectaStain ${ }^{\circledR}$ Elite ${ }^{\circledR}$ ABC HRP Kit, Vector laboratories) according to the manufacturer's protocol. Antibody binding was visualized by 3,3'-diaminobenzidine (DAB Peroxidase HRP Substrate Kit, Vector laboratories) and all tissue was counter stained with Meyer's hematoxylin. All tissue sections coverslipped with DPX mounting compound before viewing.

For immunofluorescence, after PBS washes, the tissues were blocked with normal donkey serum $(10 \%)$ in PBS containing Triton X-100 (0.3\%) for $1 \mathrm{~h}$ at room temperature. Then tissues were incubated with specific primary antibodies overnight at $4{ }^{\circ} \mathrm{C}$. After further PBS washes, the specimens were incubated with secondary antibodies conjugated with Alexa Fluor 488, 555 or 647 fluorochromes (Life Technologies) for $1 \mathrm{~h}$ at room temperature, and counterstained with DAPI (4',6-diamidino-2-phenylindole). The sections were then coverslipped with Hydromount 
medRxiv preprint doi: https://doi.org/10.1101/2021.01.22.20245217; this version posted January 26, 2021. The copyright holder for this preprint (which was not certified by peer review) is the author/funder, who has granted medRxiv a license to display the preprint in All rights reserved. No reuse allowed without permission.

Tse et al

medRxiv

(National Diagnostics). All tissue sections were examined and imaged on an upright microscope (BX53 with DP80 camera, Olympus) and imaged with 20x (UPlanSApo, 0.75 N.A.) or 40x objectives (UPlanSApo, 0.95 N.A., all Olympus) using an X-Cite ${ }^{\circledR} 120 Q$ fluorescence illuminator (Excelitas Tech Corp) and appropriate filters.

For immunocytochemistry, OLs were cultured on coverslips in 24-well tissue culture plates and fixed with paraformaldehyde (4\%) for 20 min after washing with PBS. The fixed cells were permeabilized using $0.3 \%$ Triton X-100 and blocked with normal donkey serum (5\%) in PBS for $30 \mathrm{~min}$. Primary antibodies were applied for $2 \mathrm{~h}$ at room temperature followed by PBS washes and fluorochrome conjugated secondary antibodies. Negative controls were collected by omitting the primary antibody. For high resolution imaging of the nucleus, specimens were visualized on a Leica TCS SP8 confocal laser scanning platform equipped with Leica HyD hybrid detector and visualized through a 63x/1.40 N.A Oil lens (Leica HC PL APO CS2). In each experiment, $0.3-0.5 \mu \mathrm{m}$ optical sections were imaged with constant laser power. The Zprojection of the entire optical stack was presented as a single image.

\section{Transmission electron microscopy}

The brain regions of interests (cortex, corpus callosum and cerebellum) were isolated from $\mathrm{Atm}^{-/-}$mice and their wildtype littermates for fixation, processing, ultrathin sectioning, and TEM imaging as described earlier [51]. Brain samples were diced into small pieces before immediately being frozen in a high-pressure freezing machine (EM HPM100; Leica). Specimens were ultrathin sectioned at $70 \mathrm{~nm}$ thickness using a Lecia UC7 ultramicrotome. The sections were mounted on copper grids then stained/contrasted with aqueous uranyl acetatelead citrate and visualized by Hitachi H7650 transmission electron microscope (Hitachi HighTechnologies).

\section{Image analysis}

For human tissue, six randomized images $(690 \times 520 \mu \mathrm{m})$ were taken from cerebellar GM (spanning the molecular, Purkinje and granule cell layer) and cerebellar WM (folia and deep regions). The total number of immunoreactive cells were counted per image, and their density calculated. For mouse tissues, three images $(690 \times 520 \mu \mathrm{m})$ covering the neocortex $(\mathrm{Cx})$, corpus callosum (CC) and cerebellum (CBM) were taken from three serial sagittal sections for analysis. The average count from the triplicates was taken as the density of each marker per region. For cultured cells, at least than 100 nuclei per field were counted for each condition.

\section{Western blotting and immunoprecipitation}

The left neocortex of each mouse or a human tissue section removed from a slide was lysed for protein extraction using RIPA buffer (radioimmunoprecipitation assay buffer) supplemented with phosphatase and protease inhibitors (Roche Diagnostic). Protein sample concentrations were quantified by bicinchoninic acid assay (Bio-Rad) and normalized amounts of proteins (20 - $50 \mu \mathrm{g}$ ) were electrophoresed on a 10 - 15\% SDS-polyacrylamide gels. After transfer to PVDF membranes, non-specific binding was blocked with 5\% non-fat milk followed by primary antibody incubation (Table S3). The membranes were probed with horseradish peroxidaselinked secondary immunoglobulins (Cell signalling) before visualization with chemiluminescent substrates (SuperSignal ${ }^{\mathrm{TM}}$ West Pico, Dura or West Femto Substrates, Thermo Scientific). The chemiluminescent signals were detected by blue sensitive medical Xray film, and the resulting band densities were digitalized for quantification using ImageJ software. GAPDH was used as the protein loading control. For immunoprecipitation, proteins of interests were pulled down by Dynabeads ${ }^{\mathrm{TM}}$ Protein $\mathrm{G}$ (ThermoFisher) using specific antibody prior to western blotting with target antibody. 
medRxiv preprint doi: https://doi.org/10.1101/2021.01.22.20245217; this version posted January 26, 2021. The copyright holder for this preprint (which was not certified by peer review) is the author/funder, who has granted medRxiv a license to display the preprint in All rights reserved. No reuse allowed without permission.

Tse et al

medRxiv

\section{Gene expression analysis}

The gene expression analysis of post-mortem human tissue, mouse tissue and cultured cells was performed as described [46]. Total RNA from frozen human cerebellar sections, dissected mouse brain regions or four wells of cultured cells were extracted using RNeasy mini kit (Qiagen). All contaminating genomic DNA was cleared by DNase I ( $1 \mathrm{U} / \mu \mathrm{L})$. All cDNA samples were reversed transcribed using High-capacity RNA-to-cDNA kit (Applied Biosystem). Gene expression analysis was performed using Fast SYBR ${ }^{\circledR}$ Green Master Mix (Applied Biosystem) in a Light Cycler 480 (Roche) using the human or mouse specific primers optimized by PrimerBank [52]. All gene expression levels were calculated relative to housekeeping genes (18S, $\beta$-actin and GAPDH). Data analysis was performed using $\mathrm{RT}^{2}$ Profiler PCR Array Data Analysis (Qiagen) based on the $2^{-\Delta \Delta \mathrm{Ct}}$ method [53].

\section{Protein-protein interactions and structural analysis in silico}

The sequence of the 14 clinical ATM mutants in FASTA format were map into three dimensional structure using Phyre2 server as described [54]. For all 14 models generated, between $92-99 \%$ of the residues were modelled at least $90 \%$ confidence mapped to known human ATM protein structure (PDB:5NP0A). These mutant models and the native ATM (PDB:5NP0A) were then docked with various known ATM substrate or myelin related proteins in ClusPro web server 2.0 [55]. The binding affinity between the protein structures in silico were compared and ranked based on scores measured by the estimated free energy coefficient $\left(E_{\text {balanced }}\right)$ and the cluster size. The best protein-protein interaction structures were then explored, annotated and analyzed using software ICM Browser Pro (Molsoft L.L.C).

\section{Statistical Analysis}

At least three independent experiments were performed and all data are presented as mean value \pm SEM. For pairwise comparisons, unpaired t-tests were performed. For comparisons between multiple groups, one-way analysis of variance with Newman-Keuls post hoc tests were performed. The correlations between observations were tested by Pearson correlation coefficient test. All statistical analyses were performed using GraphPad Prism software version 9.00 (GraphPad Software Inc.). The statistical significance level was set as $P<0.05$. 
medRxiv preprint doi: https://doi.org/10.1101/2021.01.22.20245217; this version posted January 26, 2021. The copyright holder for this

preprint (which was not certified by peer review) is the author/funder, who has granted medRxiv a license to display the preprint in perpetuity.

Tse et al

All rights reserved. No reuse allowed without permission.

medRxiv

\section{RESULTS}

Oligodendrocyte pathology appears early in the A-T cerebellum

Aging is often attributed to the accumulation of unrepaired DNA damage [56, 57]. An agerelated white matter loss, accompanied by a loss of oligodendrocytes (OLs), has been reported during aging [58]. Consistent with this idea, demyelination has been consistently reported in A-T and other conditions caused by DNA damage repair mutations [57]. We therefore sought to learn the fate of the OL lineage of the A-T brain. The Olig2 transcription factor marks cells at all stages of OL development, from precursors to fully mature oligodendrocytes. We examined the OLs in both gray and white matter of cerebellum from control individuals who had died with no known neurological disease (Fig 1a(i)). We found that after 60 years of age, the density of Olig $2^{+}$OLs continued to drop in a near lineage fashion in normal aging (Fig $1 \mathrm{~b}$ ). ATM expression in human cerebellum has been reported [59], but its localization in cerebellar OLs has never been documented. Using a well-characterized antibody against ATM (clone $2 \mathrm{C} 1$ ), a significant number of small and dark nuclei along the myelin fiber tracts which were strongly immunoreactive for ATM in the nucleus were also identified (Fig 1a(ii)). These ATM expressing cells were throughout the white matter areas of the human cerebella - both in the folia and in the vicinity of the deep cerebellar nuclei (Fig. 1a(ii). Based on their size, morphology and location, these cells were highly reminiscent of the pattern of Olig2 ${ }^{+}$and strongly suggests that ATM protein is also found in this cell type.

A-T is considered by many to have progeria as one of its prominent symptoms. With this normal aging data as background, we therefore examined the pathology of neurons and OL lineage in post-mortem cerebellar tissues from ten A-T subjects. First, classic atrophy of molecular, granule cell and Purkinje cells layers were readily identified. The density of Purkinje cells (PC) was highly variable but generally reduced in A-T; their soma size, however, was significantly reduced (Fig. 1c, d). Correlation analysis of the histological findings of PC density with the age of the subject revealed a significant decline in A-T (range 16 - 36 years), but steadily constant in control cases (Fig. 1e). Unexpectedly, the size of the Purkinje cells soma decreased with age in normal controls but remained small but constant in our A-T samples (Fig. 1f). We then examined the distribution and appearance of cells of the OL lineage in the A-T cerebella using antibodies against Olig2 and APC (the Quaking 7 RNA-binding protein [60] found in mature, myelinating OLs, mOL - Fig 1g, h). Quantification was performed separately in gray matter (GM) and white matter (WM). Despite the relatively young age of our cases, the density of nuclear Olig2- and CC1-positive OLs was reduced in both regions of the A-T cerebella (Fig 1j,k), although the WM Olig2 counts did not reach statistical significance.

The cellular location of the Olig2 antigen was also altered in A-T. In normal controls, the majority of the Olig2 ${ }^{+}$immunoreactivity was localized in the nucleus, consistent with its role as a transcription factor. However, in the A-T specimens, Olig2 ${ }^{+}$immunoreactivity was primarily cytoplasmic and was found in cells whose size and morphology resembled those of astrocytes. We therefore used GFAP (glial fibrillary acidic protein) immunocytochemistry to count cells in control and A-T cerebellum (Fig.1i). We found the density of GFAP ${ }^{+}$cells increased, in both GM and WM of the A-T cerebellum. OL progenitor cells (OPCs) have been reported to adopt an astrocytic cell fate after injury by shuttling Olig2 to the cytoplasm [61-64]. That is consistent with our Olig2 immunostaining (Olig2 ${ }^{+}-$Fig $1 \mathrm{~g}$, lower panel) and suggests that this phenomenon is occurring in the A-T cerebellum. 
medRxiv preprint doi: https://doi.org/10.1101/2021.01.22.20245217; this version posted January 26, 2021. The copyright holder for this preprint (which was not certified by peer review) is the author/funder, who has granted medRxiv a license to display the preprint in All rights reserved. No reuse allowed without permission.

Tse et al

medRxiv

The loss of OLs in A-T cerebellum could represent either a direct effect on the OLs themselves or an indirect effect due to neuronal (most likely Purkinje cell) dystrophy. To address this question, we evaluated whether the OL loss in A-T was a secondary consequence of neuronal degeneration. Glial cell density was not correlated with aging regardless of genotype (Fig. 1mo). In normal controls, however, the densities of $\mathrm{OLs}\left(\mathrm{CC}^{+}\right.$or Olig2 $\left.{ }^{+}\right)$were positively correlated with Purkinje cell size while the density of astrocytes (GFAP ${ }^{+}$) was negatively correlated (Fig.1 p-r). In A-T, by contrast, no association between neuronal size and glial number was found (Fig 1p-r). These findings suggested that the reduced numbers of OL in A$\mathrm{T}$ are unlikely to be secondary consequences of neuronal atrophy or death.

The effects of an ATM genotype on the transcription of genes relevant to the neuronal and nonneuronal cell function as well as genes related to DDR were further validated using real time PCR. Compared with normal control, the A-T cerebellum had significantly reduced expression of neuronal-related genes ( $S Y N 1, S Y N 2, M A P 2$, and NEUN) as well as DNA repairassociated genes (XRCC/ERCC families, $N B N, R A D 50, A T R$ ) (Figure 2a, b). Unexpectedly, myelin and mOL-related genes $(M y R F, M B P, M A G, P L P 1)$ as well as OPC-related genes $(C S P G 4, S O X 10)$ were significantly upregulated in A-T at the mRNA level. Together with the histological findings, these results suggested that the myelination in the A-T cerebella is supported by a disproportionately small population of exceptionally active OLs.

\section{Oligodendrocyte pathology is associated with the nature of the A-T mutations}

A-T is found associated with a wide spectrum of distinct ATM mutations. As a result, many individuals with A-T are compound heterozygotes of two different mutations. This genetic diversity is reflected in a substantial variation in the A-T phenotype - age of onset, severity and the specifics of clinical presentation [3]. We therefore mapped the ATM mutations using targeted genomic sequencing and detected 13 distinct ATM mutations in the ten A-T subjects (Table 1). No mutations were found in the ATM exons of control subjects $(n=10)$ nor in other DNA repair genes in any of the subjects. The 13 mutations were scattered haphazardly, if not randomly across the entire gene with five located in the FAT domain and one in the kinase domain itself (Fig. 3a). Most (64.3\%) were insertions or deletions that resulted in frameshifts. Of the remainder, $14 \%$ were single nucleotide missense/splicing mutations while $21 \%$ were amber/ocher mutations. Of the ten subjects, six were homozygous for a single ATM mutation while four were compound heterozygotes of known pathogenic mutations. This composition is similar to that found in earlier studies [3]. Frameshift mutations usually result in premature protein truncations $[65,66]$ meaning t mutations closer to the $5^{\prime}$ end of the gene tend to have a more severe clinical presentation [3]. In support of this, the age of death in our cohort of subjects tended to be earlier in persons with a frameshift mutation $(p=0.0589)$ (Fig 3b).

We then matched the histological and gene expression data with each of the mutation types (Fig. 3b). We found that Purkinje cell soma size was reduced in all cases regardless of the mutation (Fig. 3b), but that $\mathrm{CC}^{+} \mathrm{mOL}$ density was only significantly reduced in cases carrying frameshift alleles. The density of Olig2 ${ }^{+}$and $\mathrm{GFAP}^{+}$cells were not statistically different in cases with different types of mutations. For neurons, the density of Purkinje cells was only significantly reduced only in the non-frameshifts carrying cases, while the Purkinje cells soma size was similarly reduced in all A-T mutations variants (Fig. 3c). At the transcription level, OL and myelin genes $(M y R F, M B P \& G F A P)$ were significantly upregulated both in the nonframeshift and frameshift carriers. For unknown reasons $O L I G 2$ was upregulated only in cases with frameshift mutations (Fig. 3d). As expected, the neuronal genes (NEUN, RBFOX3, $T U B B 3, S Y N 1$ \& SYN2) were significantly downregulated, regardless of the ATM mutation type (Fig. 3e). These results suggest that different types of ATM mutations have different impacts on the neuronal and OL population of the cerebellum. 
medRxiv preprint doi: https://doi.org/10.1101/2021.01.22.20245217; this version posted January 26, 2021. The copyright holder for this preprint (which was not certified by peer review) is the author/funder, who has granted medRxiv a license to display the preprint in All rights reserved. No reuse allowed without permission.

Tse et al

medRxiv

\section{Myelin deficits appear early in homozygous Atm-knockout mice}

To validate the post-mortem findings in A-T cerebella, we turned to transgenic mice carrying a multiple exon deletion in the ATM kinase domain (Atm ${ }^{\text {tmlBal}}$; abbreviated $\left.\mathrm{Atm}^{-}\right)$[42]. Homozygous $\mathrm{Atm}^{-/-}$mice exhibited a clear loss of intracortical myelin fibers in frontal cortex (Cx) and shrinkage of corpus callosum (CC) even at 1 month of age (MO) relative to WT. Curiously, despite the fact that the region has the more substantial neuronal cell loss in human A-T, we found little histological evidence of myelin changes in cerebellum (CBM) (Fig. 4a). Immunoblotting revealed that the major myelin proteins including MAG, MBP, and PLP, but not MOG, were reduced in the neocortex and cerebellar cortex in $\mathrm{Atm}^{-/-}$mice (Fig. 4b, c). Of these, MAG was significantly reduced in a gene dose-dependent fashion in both regions, a finding we confirmed by immunohistochemistry (Fig. S1a). This suggests that myelin ensheathment in the periaxonal region is compromised. The other three myelin proteins, which are deposited either in the dense bands of the myelin itself (MBP, PLP) or in the OL cytoplasm (MOG), (see illustration on Fig 4c, bottom right), were less affected by the $\mathrm{Atm}^{-/}$genotype. We extended these findings through the use of transmission electron microscopy to study myelin ultrastructure in one-month old $\mathrm{Atm}^{-/-}$mice (Fig. 4d-f). Quantitative analysis revealed that the density of myelinated axons was significantly reduced in $\mathrm{Cx}, \mathrm{CC}$ and $\mathrm{CBM}$. Surprisingly, in the $\mathrm{Atm}^{-/}$corpus callosum and cerebellum, the average axon diameter actually increased. We also measured the g-ratio as a measure of the thickness of the myelin sheath. By this criterion, myelin thickness in cortex and cerebellum was largely unchanged while it thinned significantly in corpus callosum.

\section{Oligodendrocyte pathology in Atm-knockout mice}

To test the hypothesis that the myelin deficits in $\mathrm{Atm}^{-/}$mouse were intrinsic to OLs themselves, the number of OLs in in $\mathrm{Atm}^{-/}$and wild type mice at 1 and $6 \mathrm{MO}$ were quantified by immunohistochemistry (Fig. 5a-d). The total number of OLs was assessed by Olig2 expression, while the number of OPCs and mature OLs were quantified using NG2 and MyRF/CC1, respectively. A major difference in OL pathology between brain regions was found. In the cerebellum, between one and six-months of age, the number of actively myelinating $\left(\mathrm{MyRF}^{+}\right)$ OLs increased in both genotypes. This was true even though the total numbers of Olig2 ${ }^{+}, \mathrm{NG}^{+}$ and $\mathrm{CC}^{+}$cells were significantly reduced with both age and genotype (Fig. 5a-d, bottom row). This is consistent with the concept that despite their reduced numbers the remaining cells of the OL lineage in cerebellum are more synthetically active.

The picture in the $\mathrm{Atm}^{-/}$neocortex was distinctly different. Here the total number of cells in the OL lineage (Olig2 ${ }^{+}$) remained constant in wild type but actually increased in older $\mathrm{Atm}^{-/}$. The number of precursors increased with age in both genotypes even though the number of $\mathrm{Atm}^{-/-}$OPCs always trailed those found wild type animals (Fig. 5a, b, top row). The number of $\mathrm{MyRF}^{+}$cells in neocortex was also reduced in $\mathrm{Atm}^{-/}$animals but, unlike the situation in cerebellum, the numbers remained constant from one to six months. There was also a significant reduction of mature OLs $\left(\mathrm{CC}^{+}\right)$in neocortex. This occurred in both genotypes although the number of $\mathrm{CC}^{+}$cells in the mutant was always less than those found in wild type. The neocortex is thus distinct from cerebellum and suggests a failure of differentiation despite an increase in progenitor cells in this brain region.

In the corpus callosum, no significant differences of the total $\mathrm{Olig}^{+} \mathrm{OL}$ or $\mathrm{NG}^{+} \mathrm{OPC}$ population were found, but mature OLs $\left(\mathrm{MyRF}^{+} \mathrm{Olig} 2^{+}\right.$and $\left.\mathrm{CC}^{+} \mathrm{Olig} 2^{+}\right)$were reduced in an age- and genotype-dependent fashion (Fig. 5a-d, middle row).

The histological results from all three areas were largely confirmed by analysis of mRNA and protein levels for various neuronal and OL related genes. The regional variation in the response of the OL population to a deficiency of ATM is borne out at the molecular level (Fig. 5e-h). In 
medRxiv preprint doi: https://doi.org/10.1101/2021.01.22.20245217; this version posted January 26, 2021. The copyright holder for this preprint (which was not certified by peer review) is the author/funder, who has granted medRxiv a license to display the preprint in All rights reserved. No reuse allowed without permission.

Tse et al

medRxiv

$\mathrm{Atm}^{-/-}$neocortex, OPC genes (Cspg4 [i.e., NG2] and Cnp) as well as mature OLs genes (Mbp, Plp, Myrf and Mag) were significantly downregulated (Fig. 5e). With the notable exception of Olig2, the protein levels we measured were also reduced (Fig. 5f). In the cerebellum, despite the overall reduction of OLs and OPCs numbers, most myelin-related transcripts, though trending lower, were largely unchanged in $\mathrm{Atm}^{-/}$mice (Fig. 5g, h). Taken together the results suggest that while OL numbers are unchanged in neocortex, their myelin synthetic activity is markedly reduced. In cerebellum, cell number was reduced, but the myelin synthetic activity was unchanged.

\section{ATM deficiency results in DSB damage in oligodendrocytes}

Chronic loss of ATM activity promotes DSBs formation in many cell types [67], and we found the same to be true in the OL population. In A-T, an increased fraction of cerebellar nuclear Olig2 ${ }^{+}$cells were double positive for 53BP1, an increase found in both GM and WM (Fig. 6a, $\mathrm{b}$,). Intriguingly, a strong nuclear 53BP1 signal was detected among the astrocyte-resembling, fibrillar Olig2 ${ }^{+}$population (insets). To determine whether the increased DSBs in the OL lineage was due to defects in the oxidative stress mechanisms [68], we used immunohistochemistry of 8-OHdG (8-hydroxy-2'-deoxyguanosine) to assess oxidative DNA damage in the Olig2 ${ }^{+}$OLs. By this metric DNA oxidation was high in both genotypes (about $50 \%$ ), with no significant difference between wild type and $\mathrm{Atm}^{-/-}$mice (Fig. 6c). Using $\gamma \mathrm{H} 2 \mathrm{AX}$ as a marker of DNA breakage, neocortical Olig2 ${ }^{+}$OLs exhibited were 2 .4-fold more likely to be nuclear $\gamma \mathrm{H} 2 \mathrm{AX}$ labelled than $\mathrm{Atm}^{-/-}$OLs (Fig. 6d, $p=0.0519$ ). To further test the effects of oxidative stress and ATM deficiency, we turned to experimental cell culture models. We found that hydrogen peroxide $\left(\mathrm{H}_{2} \mathrm{O}_{2}\right)$ treatment induced significant DSB formation, astrogliosis and cell loss in a well-established OPC cell line, Oli-Neu [69], as well as in primary OPC culture (Fig. S2a-j). Of note, the cytotoxic effects of $\mathrm{H}_{2} \mathrm{O}_{2}$ were exaggerated in the presence of the ATM inhibitor KU-60019 [70] (Fig. S2g-j). Importantly, KU-60019 alone caused a similar accumulation of DSB $\left(\gamma \mathrm{H} 2 \mathrm{AX}^{+}\right.$or $53 \mathrm{BP} 1^{+}$, Fig. 6e, f) in Oli-Neu cells. Together, these data support our hypothesis that ATM deficiency results in the accumulation of DSBs in OLs.

\section{ATM deficiency or activation by DSBs differentially deplete OPCs through cell cycle control}

To investigate whether the OL and myelin degeneration in A-T subjects and $\mathrm{Atm}^{-/-}$were indirect consequences of pre-existing neuronal pathology, we employed an enriched OL culture that was neuron-free. In cultured OPC $\left(\mathrm{NG}^{+}\right)$, ATM immunoreactivity is found in both nucleus and cytoplasm (Fig 7a). Unexpectedly, activated ATM (pATM ${ }^{\text {ser1981-positive) was }}$ predominantly cytosolic, including prominent immunoreactivity extending into the cellular processes (Fig. 7b). Blocking ATM autophosphorylation with KU-60019 essentially eliminated pATM ${ }^{\text {ser1981 }}$ staining (Fig. 7b, right and Fig. 7c). Despite its prominence in the OPC, blocking ATM activity with KU-60019 had virtually no effect on OPC $\left(\mathrm{NG}^{+}\right)$or total OL $\left(\right.$ Olig2 $^{+}$) survival. Etoposide, by contrast, induced a dose-dependent loss of both (Fig. 7d, e). The suggestion is that the OPC population is more vulnerable to DNA damage than to loss of ATM activity.

Both DNA damage and ATM activity are known to alter cell cycle kinetics, but the situation in cultured OPCs revealed an unexpected distinction between them. Whereas KU-60019 reduced the number of cycling NG2 ${ }^{+}$OPCs by half only at the highest concentrations (Fig. 7e, f), etoposide abolished CCA2 expression entirely. Further, using EdU incorporation to examine DNA incorporation, we confirmed that the percentages of OPC and total OL entering S phase $\left(\mathrm{NG}_{2}{ }^{\mathrm{EdU}} \mathrm{U}^{+}\right.$, Olig2 $\left.{ }^{+} \mathrm{EdU}^{+}\right)$dropped dramatically in etoposide even at 100 -fold lower drug concentrations (Fig. 7g, h). These data suggested that OPC cell cycle progression in $\mathrm{S}$ phase is more highly sensitive to DNA damage than to ATM deficiency. 
medRxiv preprint doi: https://doi.org/10.1101/2021.01.22.20245217; this version posted January 26, 2021. The copyright holder for this preprint (which was not certified by peer review) is the author/funder, who has granted medRxiv a license to display the preprint in perpetuity.

Tse et al

All rights reserved. No reuse allowed without permission.

medRxiv

\section{DSBs-induced ATM activation disrupt cell cycle control in myelinating $O L$}

As in NG2-positive OPCs, ATM and pATM $^{\text {ser1981 }}$ are found in the nucleus, cytoplasm, and processes of cultured MBP-expressing mOLs (Fig. 8a-c). Mature oligodendrocytes are postmitotic. By DIV7, less than 5\% of the MBP-expressing cells expressed either cyclin D1 or cyclin A2. By contrast, over $30 \%$ of the $\mathrm{NG}^{+}$OPC remained cell cycle-positive (Fig. 8d, e). Low concentrations of KU-60019 $(0.1$ and $1 \mu \mathrm{M}, 24 \mathrm{~h})$ induced a small but significant increase in Cyclin D1 mOLs (Fig. 8f, g, upper row), but this increase was not productive as there was no change in total mOL number. Curiously, etoposide induced cyclin D1 expression (G1-phase) in mature OLs (Fig. 8f, g, lower row) despite the fact that it blocked EdU incorporation (Sphase) in $\mathrm{NG}^{+}$cells (Fig. 7h). Neither treatment had a significant effect on either the number or cell cycle activity of primary cortical neurons (Fig. 8f, g). This is consistent with the higher sensitivity to DNA damage of mature OLs compared with neurons [46].

We have previously shown that cycle progression in mature OL is associated with cell death [58]. Using cleaved caspase 3 (CC3) as a measure of apoptosis (Fig. 9a), we found that etoposide $(10 \mu \mathrm{M})$, but not KU-60019 $(10 \mu \mathrm{M})$, or $\mathrm{H}_{2} \mathrm{O}_{2}(50 \mu \mathrm{M})$, significantly induced the abnormal re-expression of cyclin D1 (50.2\%) and ectopic cell cycle-related cell death $(19.2 \%)$ in mature, MBP-expressing OLs (Fig. 9b). Etoposide was the only treatment that significantly increased the number of mOL co-expressing both cyclin D1 and CC3 (6.6\%). In contrast, KU60019 directly triggered apoptosis and degeneration in $25.3 \%$ of the mOLs population but did so without inducing cyclin D1 (Fig. 9b-e). Curiously, unlike the immature OPC population, oxidative stress induced by $\mathrm{H}_{2} \mathrm{O}_{2}$ had no toxic effects on mOLs. Ectopic cell cycle-related Purkinje cell death has been reported in $\mathrm{Atm}^{-/-}$mice $[42,43,59,71,72]$. We have now extended these pathological findings to cerebral cortex (Fig. S1b-d) and confirmed the presence of ectopic cell cycles in the mature OL population in different brain regions of the $\mathrm{Atm}^{-/-}$mice (Fig. 9f-i). We found a two to four-fold increase of cell cycle positive mature OLs in the neocortex, corpus callosum and cerebellum at both one and six months of age. We also found a significant increase in cyclin D1 in $\mathrm{CCl}^{+}$and $\mathrm{MyRF}^{+}$mOLs of $\mathrm{Atm}^{-/-}$mice in neocortex, corpus callosum and cerebellum at one and six months of age (Fig. 9f-i). Abnormal cyclin D1 re-expression was also identified in the $\mathrm{MyRF}^{+}$mOLs in the corpus callosum of $\mathrm{Atm}^{-/-}$mice at one month of age, but no significant increase was observed in neocortex or cerebellum. This pattern of ectopic CCE was closely associated with the pattern of mOL loss in the $\mathrm{Atm}^{-/-}$mice.

\section{ATM controls DSB-induced cell cycle-related deaths in postmitotic $\mathrm{mOL}$}

These experiments define an important distinction between the immature and mature cells in the oligodendrocyte lineage in their vulnerability to an ectopic cell cycle event. To explore this further, we forced cell cycle re-entry of fully established mOL at DIV14 using the OLspecific growth factors PDGF-AA and bFGF $(10 \mathrm{ng} / \mathrm{mL})$. The growth factors drove the abnormal expression of cyclin D1, and increased DNA damage $\left(\gamma \mathrm{H} 2 \mathrm{AX}^{+}\right.$foci). The effects were similar to those found after etoposide exposure (64\% and 69\% respectively, Fig. 10a). One important difference was that the growth factors induced EdU incorporation (Fig. 10b) while none of the other agents did. The effect was especially apparent after $72 \mathrm{hrs}$ of treatment. To more carefully assess cell cycle progression in our cultures, we measured cyclin D1 expression as a measure of cells in G1, cyclin A2 to measure cells at the G1/S transition and EdU incorporation as a marker for cells in $\mathrm{S}$ phase. Cell death (apoptosis) was measured with cleaved caspase-3 (CC3) (Fig. 10c-f). While both etoposide and growth factors triggered the expression of cyclin D1, only the growth factors induced the reexpression of cyclin A2 (Fig 10c, d). Intriguingly, etoposide and KU-60019 suppressed even the background levels of cell cycle activity (cyclin A2 expression and EdU incorporation). Despite their differential effects on cell cycle re-entry, all three treatments induced significant apoptosis in mOL (Fig. 10f). 
medRxiv preprint doi: https://doi.org/10.1101/2021.01.22.20245217; this version posted January 26, 2021. The copyright holder for this preprint (which was not certified by peer review) is the author/funder, who has granted medRxiv a license to display the preprint in All rights reserved. No reuse allowed without permission.

Tse et al

medRxiv

As a final test, we asked whether ATM was required during DSB- and mitogen-induced CCE. The mOLs culture was treated with KU-60019 $(10 \mu \mathrm{M}), 30 \mathrm{~min}$ prior to the addition of etoposide or growth factors. We found that inhibition of ATM activity completely suppressed the DSBs-induced re-expression of cyclin D1 (Fig. 10g), abolished the ectopic cell cyclerelated apoptosis (Fig. 10h), but potentiated the DSBs-induced apoptosis in mOL (Fig. 10i). In contrast, ATM activity inhibition did not interfere with growth factors-induced CCE and the associated apoptosis (Fig. 10g-i). These findings suggested that ATM regulates the DSBsinduced, but not growth factor-induced, cell cycle protein re-expression and CCE-related cell death even in postmitotic mOLs, consistent with its well-established role as a G1/S checkpoint protein [73].

Endogenous ATM activity is required for the formation of myelinating oligodendrocytes

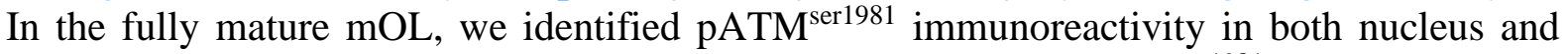
cytoplasm (Fig 8b). In the newly formed mOL, the cytoplasmic pATM $^{\text {ser1981 }}{ }^{\text {was localized not }}$ only inside the cell body, but also in the cytoplasm of the MBP-positive branches (Fig. 11a(ii)(iii)). Despite the close proximity, we observed no evidence of co-localization of pATM $^{\text {ser1981 }}$ and MBP. In mOL where established sheets of MBP were formed, pATM ${ }^{\text {ser1981 }}$ immunoreactivity persisted in the major branches of cytoplasm but was absent in the vallate MBP-labeled cytoplasmic extensions (Fig. 11b(ii)-(iii)). We previously used immunoprecipitation-based liquid chromatography-mass spectrometry (IP-LCMS) to identify proteins interacting with ATM in mouse brain [25]. Although we did not pursue it in this original study, we found that MBP, PLP and MOG were physically associated with ATM in mouse brain lysates, consistent with our speculation that ATM plays a role in the maturation of the OL lineage [57].

Seen in the context of the cell fate switch we observed, the functions of ATM during OL differentiation are even more complex. OPCs accumulate in $\mathrm{Atm}^{-/-}$mice (Fig. 5a), and Atm deficient neural stem cells fail to form $\operatorname{mOL}[38,39]$. This suggests that endogenous ATM activity is also required for a normal OPC to differentiate into a mature, myelinating oligodendrocyte. To test this, OPCs were chronically incubated with a low concentration of KU-60019 throughout the seven-day differentiation period (Fig. 11c). Quantification of $\mathrm{MBP}^{+}$ and $\mathrm{MAG}^{+} \mathrm{OL}$ at DIV7 revealed that the maturation of the OPC is highly sensitive to endogenous ATM activity (Fig. 11d, left). Furthermore, the inhibition of ATM suppressed the fraction of cells with nuclear-localized Olig2 and MyRF (Fig 11d, right). Focusing on the final steps in maturation to mOL, we found that at the concentration of KU-60019 $(1 \mu \mathrm{M})$ that halved the $\mathrm{MBP}^{+}$and $\mathrm{MAG}^{+}$expression, there was no inhibition of nuclear translocation of Myrf (Fig. 11e). Nevertheless, the chronic inhibition of endogenous ATM activity over 7 days of treatment $(1 \mu \mathrm{M})$ significantly reduced the transcription of Myrf, Plp, and Mag (Fig. 11f) and revealed a gradual loss of nuclear Olig2 expression (Fig 11g). These findings suggest that the transcription program that leads to the OL maturation requires endogenous ATM activity.

MyRF is the master myelin transcription factor responsible for active myelin formation in mOL. To address the functions of ATM on MyRF, we performed additional experiments on Oli-Neu cells. Oli-Neu cells constitutively express nuclear MyRF and can be differentiated with cyclic AMP into MAG-expressing cells thus mimicking the maturation of a myelinating OL (Fig. 11h, i). Consistent with our findings in primary OLs, ATM kinase inhibition attenuated the cAMPinduced differentiation of Oli-Neu cells, albeit without any effects on the nuclear localization of MyRF. At the molecular level, both the cAMP-induced and baseline level of Mag gene expression were abolished by KU-60019 (Fig. 11j, k), suggesting ATM activity directly affects myelin gene transcription. To confirm these results, we performed shRNA-mediated knockdown down of both ATM as well as the related phosphatidyl-inositol 3-kinase family 
medRxiv preprint doi: https://doi.org/10.1101/2021.01.22.20245217; this version posted January 26, 2021. The copyright holder for this preprint (which was not certified by peer review) is the author/funder, who has granted medRxiv a license to display the preprint in All rights reserved. No reuse allowed without permission.

Tse et al

medRxiv

member, ATR (ATM and RAD3-related kinase). We found that knockdown of ATM, but not ATR, reduced the number of cells with nuclear MyRF (Fig. 111). However, both ATM-shRNA and ATR-shRNA significantly blocked Oli-Neu differentiation with suppressed MAGexpression upon cAMP treatment (Fig. $11 \mathrm{~m}$ ). These findings suggest that nuclear localization of MyRF requires ATM while myelin gene transcription requires both ATM and ATR.

\section{Myelin and OL related proteins rich in S/TQ motifs are putative ATM substrates}

In response to DSBs, ATM and ATR phosphorylate a spectrum of protein substrates at SQ or TQ sites (amino acid motifs with serine (S) or threonine (T) followed by a glutamine (Q)). Once these [S/T]Q cluster domains (SCD, defined by at least 3 [S/T]Q sites per 100 amino acids) are phosphorylated, the substrate is activated and helps to orchestrate the DNA damage response. Most of the known ATM substrates responsible for cell cycle control and DNA repair contain a number of SCDs (Table 2). We therefore searched for SCDs in myelin proteins, common OL markers as well as OL-associated transcription factors using SCDFinder [74]. Both mouse MBP and MyRF were identified as having relatively high concentration of SCDs (Table 2). Immunoblots of cortical lysates demonstrated the significance of these residues as a reduction of phosphorylated $[\mathrm{S} / \mathrm{T}] \mathrm{Q}$ motifs $(\mathrm{p}[\mathrm{S} / \mathrm{T}] \mathrm{Q})$ on a spectrum of molecular weight in a gene-dose dependent fashion (Fig 12a, b). To evaluate if there were any [S/T]Q sites on mouse MBP or MyRF proteins that might be phosphorylated by ATM, brain tissue lysates were immunoprecipitated by anti-MBP and anti-MyRF and probed with an anti-p[S/T]Q antibody (Fig. 12c-e). Despite significant variations, $\mathrm{p}[\mathrm{S} / \mathrm{T}] \mathrm{Q}$ signals were detected in both immunopreciptiates and such signals were lower in $\mathrm{Atm}^{-/-}$mice (Fig. 12d, f).

\section{Mapping the interactions of MBP and MyRF with ATM}

We next used in silico methods to predict the sites of ATM interaction with MBP and MyRF. Mouse MBP contains five S/TQ sites arranged in two SCDs (red, Fig 13a). We searched for docking sites between a highly conserved central segment of mouse MBP (PDB:2LUG) and human ATM structure (PDB: 5NP0, A Chain) using the ClusPro protein docking software [55]. In the most likely model of interaction, the $E_{\text {balanced }}$ weighted score between MBP and ATM was estimated as $-1123.6 \mathrm{KJ} \mathrm{mol}^{-1}$ with 206 members in the contact cluster. The visualization of this model revealed that MBP (yellow) is buried within the spiral and pincer region of ATM [75] (Fig 13b - skyblue mesh). The three [S/T]Q sites (red) on MBP were arranged within $\sim 15$ Ångstroms ( $\AA$ ) of each other (Fig. 13c). Residue Q100 and Q105 are predicted to make a close contact with ATM at K1387 and H488 respectively and both are predicted to form hydrogen bonds (skyblue mesh with yellow shaded contact area) of approximately 1.83-1.89 $\AA$ (Fig. 13c(ii), c(iii)). Importantly, the serine residue at S99-Q100 of MBP is a known phosphorylation site and could well serve to regulate the compaction of myelin sheath [76].

In the protein structure of mouse MyRF, 13 [S/T]Q sites were identified in groups of three SCDs. MyRF is a membrane associated transcription factor resident normally in the Golgi apparatus or endoplasmic reticulum. It translocates to the nucleus once the $\mathrm{mOL}$ begins active myelination [77]. Most of the 13 [S/T]Q sites were concentrated in the cytoplasmic region towards the C-terminus; only one was identified in the nuclear fragment towards $\mathrm{N}$-terminal. The three-dimensional structure of MyRF has not been fully worked out. Therefore, we investigated its potential interaction with ATM using the Ndt80-like DNA binding domain (DBD, green - PDB: 5H5P), with the native human ATM structure. In the most likely model of interaction, the $E_{\text {balanced }}$ weighted score was estimated as $-1225 \mathrm{KJ} \mathrm{mol}^{-1}$ with 113 members in contact. Two major contact areas between MyRF-DBD and the pincer region of the ATM were identified (Fig. 14c), where six residues of MyRF-DBD form multiple hydrogen bonds with seven residues of ATM at a distance of 1.75-2.08 $\AA$ (Fig. 14c(i)(ii)). 
medRxiv preprint doi: https://doi.org/10.1101/2021.01.22.20245217; this version posted January 26, 2021. The copyright holder for this

preprint (which was not certified by peer review) is the author/funder, who has granted medRxiv a license to display the preprint in All rights reserved. No reusetuity.

Tse et al

medRxiv

Clinical mutants with defective MBP-ATM or MyRF-ATM interactions result in OL loss To investigate the clinical implications of the MBP-ATM and MyRF-ATM interactions, we mapped the 13 unique clinical ATM mutant variants onto the native human ATM structure (PDB:5NP0) as template using Phyre ${ }^{2}$ (Protein Homology/analogY Recognition Engine V 2.0 [54]). All three-dimensional models of the ATM mutation variants are illustrated in Fig. S3. The clinical mutant variants were found throughout the length of ATM with seven located in the Spiral and Pincer regions and six located at the FAT-Kinase domain (Fig 15a, b). These mutant models were docked with known human ATM substrates (53BP1, P53, 53BP1-P53 complex and 53BP1-p53-H2AX complex) or myelin-related proteins of mouse or human origins (MBP, MyRF and PMP2) using ClusPro. Consistent with our prediction, the evaluated docking score of the MBP and MyRF with native ATM were comparable to that of known ATM substrates (Fig. 15a). Using free energy release (less negative $E_{\text {balanced) }}$ as a metric, we found that the docking affinities of the seven mutants terminating or truncating the spiral or pincer region (L1238K, T1029N, L782V, E522I, C430del, L315Y and R248del) were lower than the six FAT-Kinase domain mutations (R2032K, R2136del, R2443del, D2625Q, N2679S, W2960del) (Fig. 15b).

The visualization of mutant docking models revealed the loss of the putative contact sites of MBP-ATM and MyRF-ATM in mutants with early terminations (exemplified by L315Y, Fig. 15c), but not for mutants terminating at the FAT-Kinase domain (exemplified by R2443del, Fig. 15d). This observation was confirmed by the significantly stronger docking estimation between mutants terminating late $(\geq 2032)$ with known ATM substrate and myelin proteins than those terminating early $(\leq 1238)$ (Fig. 15e). Intriguingly, peripheral nerve specific myelin protein, PMP2, exhibited minimal interactions with ATM and any ATM variant. These results suggest that both pincer and spiral region of ATM, a known region to harbor ATM substrate such as p53 and Nbs1 [75], may also interact with myelin proteins. As a final experiment, we asked if the ATM mutants terminating at or earlier than the pincer region $(\leq \mathrm{L} 1238$ position) were correlated with a more severe cerebellar pathology. In terms of OL population, a significantly reduced number of Olig2 ${ }^{+} \mathrm{OL}$ was found in the early terminated mutants (Fig. $15 \mathrm{f}$ ). Despite the remarkably lowered number of $\mathrm{CC}^{+} \mathrm{mOL}$, no statistical significance was found with this feature. No difference in astrogliosis or Purkinje cell number was detected. However, our correlation analysis revealed that the larger soma size of Purkinje cells was correlated with a higher affinity (more negative docking scores) between the ATM mutant and known its substrate (53BP1-P53) or myelin protein (MBP), suggesting an indirect effect on AT neuropathology (Fig. 15g). 
medRxiv preprint doi: https://doi.org/10.1101/2021.01.22.20245217; this version posted January 26, 2021. The copyright holder for this

preprint (which was not certified by peer review) is the author/funder, who has granted medRxiv a license to display the preprint in perpetuity.

Tse et al

All rights reserved. No reuse allowed without permission.

medRxiv

\section{DISCUSSION}

Myelin deficits of the central nervous system are a prominent pathological feature in A-T [26, $33,36,78]$. While these abnormalities have been assumed to be secondary consequences of the pronounced neuronal degeneration, direct evidence of this assumption is lacking [34, 79]. Indeed, white matter degeneration and possible abnormal myelin turnover are seen early in the A-T disease process (range $6.6-22$ years) $[26,78,80]$, a finding in agreement with the reduced number of Olig $2^{+}$and $\mathrm{CC}^{+}$cells found in our youngest case (16 years, case AT5). At all ages, the numbers of OLs remaining in the cerebellum was not correlated with any measure of Purkinje cell integrity - cell number or cell size. If the OL dystrophy were secondary to a neuronal phenotype, this should not be the case. This is not to say that the remaining OL are completely insensitive to the neuronal dystrophy. Our gene expression studies show an upregulation of OL-related genes in A-T, even as neuron-related genes are down-regulated. As the numbers of Olig2+ cells are reduced, the suggestion is that the remaining OLs must push their synthetic capacity to its limit. Taken together, one logical interpretation of these results is that of the myelin pathology in A-T is both a direct consequence of ATM deficiency in the OL lineage itself as well as the indirect consequence of the loss of the interaction with neurons. Our finding of OL defects as early as one month in the $\mathrm{Atm}^{-/-}$mouse model, where there is little to no Purkinje cell death and few detectable structural abnormalities [81], further supports such a model.

Consistent with the well-known heterogeneity in the genotype and clinical phenotypes of A-T [3], substantial variations in OL pathology were found among the cases we examined. Indeed, two observations suggest that the OL lineage is more sensitive than neurons to the nature of the ATM mutation. First, in subjects with ATM frameshift mutations, a greater loss of OLs was found compared with non-frameshift carriers. Second, regardless of the mutation type, the OL lineage was found to be more vulnerable to terminating mutations located at early positions that disrupt the spiral and pincer regions in the N-terminal than those mutants impacting the FAT-Kinase domain of the ATM structure. Neither Purkinje cell structure (density and size) nor overall neuronal gene expression followed this trend. This is additional support for the idea that ATM deficiency has OL-specific, cell autonomous consequences.

These conclusions from human A-T are validated by our findings in $\mathrm{Atm}^{-/-}$mice $[7,25,72,82]$, where widespread myelin deficits - at the transcriptional, translational and ultrastructural level - recapitulate the white matter abnormalities found in human A-T cases [27-31]. The mouse data also reveals important heterogeneity among different brain regions. The combined histological and molecular picture suggests that in cerebellum, the number of cells of the OL lineage is reduced, but the synthetic activity of each individual OL increases. In neocortex, by contrast, OL cell number is largely unaffected, but the level of message and protein for a range of OL-related genes is significantly depressed. Further, by comparing one-month with sixmonth animals, we find that it is the mature, myelin-forming OL population $\left(\mathrm{MyRF}^{+}\right.$and $\left.\mathrm{CCl}^{+}\right)$ that is the most vulnerable to ATM deficiency. Combining the results of two regions, it would appear that in cortex, both neurons and OL are compromised at the molecular, but not at the structural level. In cerebellum, by contrast, the effects are felt most acutely by both cell types in the structure of the myelin, but the remaining OLs are either unaffected or enhanced in their synthetic output. The sequence of pathological events, that is, whether OL or neuron first fall into a pattern of degeneration in the $\mathrm{Atm}^{-/-}$brain remains a question for future investigations. Nevertheless, the cell model we employed strongly suggested that there are aspects of the OL pathology in A-T or $\mathrm{Atm}^{-/-}$mice that are independent of neuronal pathology. 
medRxiv preprint doi: https://doi.org/10.1101/2021.01.22.20245217; this version posted January 26, 2021. The copyright holder for this preprint (which was not certified by peer review) is the author/funder, who has granted medRxiv a license to display the preprint in All rights reserved. No reuse allowed without permission.

Tse et al

medRxiv

\section{ATM control cell cycle progression in the entire oligodendrocyte lineage}

Our molecular analyses showing that myelin basic protein and myelin regulatory factor are putative ATM substrates, offering possible insight into the mechanistic basis of the oligodendrocyte and myelin anomalies found in the brains of persons with A-T. By linking specific ATM mutations to the severity of OL pathology, we provide a deeper perspective on the complex neurological phenotype of A-T.

ATM is one of the three key DDR kinases that facilitates DSB repair by suppressing the cell cycle during the repair process. Our findings make it clear that this DDR function of ATM also applies to the oligodendrocytes. Unlike neurons, the OL lineage maintains a mitotically active progenitor cell population of OPC in the adult brain [83,84]. While both mature neurons and mOLs are post-mitotic, the survival and proliferation of OPCs are highly sensitive to the levels of DSBs formation and to ATM activity, a conclusion supported by our observation that the reduction of OPC density in the $\mathrm{Atm}^{-/-}$neocortex and cerebellum appears to be the consequence of failed OPC self-renewal. This supposition agrees with earlier observations in $\mathrm{Nbn}^{\mathrm{Cns} \text {-del }}$ mice, where OPCs also fail to proliferate in the absence of Nbn, an upstream regulator of ATM [85]. In addition, OPC and immature OL express low levels of antioxidants and are thus poorly defended against oxidative stress [68]. We and others have demonstrated that when ATM activity is deficient, oxidative stress will often lead to DSB formation [20,86]. This is important context for our finding that enhanced oxidative stress associates with OPC genomic damage in A-T and $\mathrm{Atm}^{-/-}$mice. The implication of these observations is that ATM activity is required to counter the oxidation-induced loss of genomic integrity in OPC and thereby ensure error-free self-renewals, similar to the situation in neural stem cells [87]. Mature, myelinating OLs, by contrast, are resistant to oxidative stress (Fig. 9), but susceptible to other forms of DNA damage.

It is instructive to compare these findings in the OL lineage with a second type of terminally differentiated brain cell, the neuron. Similar to neurons, myelinating, mature OLs exit the cell cycle at the beginning of their final differentiation program $[88,89]$. In neurons, the loss of ATM signaling results in aberrant cell cycle re-entry $[7,82,90]$ and structural atrophy $[72,91]$. In different neurodegenerative diseases, these neuronal cell cycles are occurring only in affected brain regions. Thus, in A-T, ectopic "cycling" is found in Purkinje neurons of the cerebellum, but not in hippocampus. In Alzheimer's disease (AD), by contrast, such abnormal neurons are found in hippocampus but not in cerebellar cortex. As in A-T, it appears that the loss of ATM activity in AD is a likely initiator of the sequence of events leading to ectopic neuronal cell cycle events [92]. A similar connection between cell cycle and cell death in found among the oligodendrocytes. In both $\mathrm{AD}[46]$ and $\mathrm{A}-\mathrm{T}$ the abnormal re-expression of cell cycle proteins in postmitotic mOLs results in myelin abnormalities coupled with OL cell death.

There are, however, distinct differences between the cell cycle/cell death relationship in neurons and oligodendrocytes. Most notably, "cycling" neurons appear to survive in vivo for months if not longer after initiating a cell cycle [reviewed in reference \#93]. We show here that postmitotic mOLs at risk for cell death also abnormally re-express cell cycle proteins, but their death follows quickly, both in vivo, and in vitro. Our data show that ATM deficiency drives the mOL to re-enter G1 phase (cyclin D1 expression) but they appear unable to pass the G1/S transition or enter S phase. Further, in mOLs, loss of DNA integrity is only one pathway by which a mature oligodendrocyte can be forced to enter an ectopic cell cycle. Our data also show that the PDGF and FGF mitogens also drive replication in postmitotic OL. Curiously, growth factor-induced cell death is not driven by the cell cycle events themselves. This suggests that, only following the DSBs-induced mitotic activity does ATM regulate cell death, perhaps by altering the choice between DNA repair and apoptosis. 
medRxiv preprint doi: https://doi.org/10.1101/2021.01.22.20245217; this version posted January 26, 2021. The copyright holder for this preprint (which was not certified by peer review) is the author/funder, who has granted medRxiv a license to display the preprint in perpetuity.

Tse et al

All rights reserved. No reuse allowed without permission.

medRxiv

ATM is required to maintain cell fate and differentiation of oligodendrocytes

ATM plays roles in the cell cytoplasm as well as its nucleus [7, 20, 25]. Cytoplasmic ATM is found in or on organelles, including mitochondria [12] and synaptic vesicles [25, 94], where it serves a variety of functions independent of DNA repair [14, 25, 95]. In neuronal cell lines, cytoplasmic translocation of ATM is associated with terminal differentiation [6]. Seen in this context, the accumulation of OPCs despite the reduced present of myelin in $\mathrm{Atm}^{-/-}$brain is consistent with the idea that the OL differentiation program is blocked due to its ATM dependence. During the OL maturation process activated ATM (pATM ${ }^{\mathrm{ser} 1981}$ ) is found to be a prominent feature of the developing cytoplasmic branches of the differentiating MBP-positive mOLs. In two independent models of OL differentiation, ATM inhibition by KU-60019 or gene silencing significantly attenuated myelin gene transcription. This block occurred in the absence of any effects on MyRF nuclear localization which only occurs in actively myelinating mOL [88]. As MyRF and Olig2 are the key transcription factors that orchestrate myelination [96, 97], our findings suggest that the loss of endogenous ATM activity leaves the cell in an ambiguous state of differentiation. We propose that in response to the lowered levels of Olig2 in A-T some terminally differentiated OLs begin to divide again. As a result, they enter a lethal cell cycle stall that leads to their death. As the reduction of Olig2 in OPC coincides with the astrogliosis, , the combined effects of ATM on cell cycle and Olig2 may drive the substantial astrogliosis in A-T $[27,29,31,98,99]$. These observations provide a molecular mechanism underlying the failure of $\mathrm{Atm}^{-/-}$neural stem cells to differentiate into mOLs [38-40].

\section{Oligodendrocyte-specific interactions between ATM and myelin related proteins}

Our in silico modeling offers new and unexpected insights into why ATM has such significant effects on the cells of the oligodendrocyte lineage. The docking studies (Figs. 13-15) illustrate how ATM could interact directly with both MBP and MyRF. This theoretical fitting exercise receives important validation from our finding that both myelin-related proteins can be coimmunoprecipitated with an ATM antibody. Also, MBP and MyRF are likely to be specific ATM substrates as both contain a high density of [S/T]Q sites. Indeed, the free energy scores of the modeled interaction of ATM with these two proteins are comparable to those seen with known ATM substrates. Our finding that most of the cerebellar OL population were lost in the clinical mutants with a shorter peptide sequence terminating at the docking site in the spiral and pincer regions of the ATM structure would be predicted based on this hypothesis. Also noteworthy is that one of the identified [S/T]Q sites in MBP is known to regulate myelin compaction [76]. It is tempting to speculate that the ATM-dependent cell death of mature oligodendrocytes (without cell cycle involvement) is the consequence of a failure of this ATMMBP interaction. The consequences of the interaction between MyRF with ATM are more difficult to predict. We were unable to perform structural modeling of the cytoplasmic fragment of MyRF due to the lack of known structural constraints. This is regrettable as this region is rich in $[\mathrm{S} / \mathrm{T}] \mathrm{Q}$ sites. By contrast, the identified docking site for the DNA binding fragment that we were able to model is not near any $[\mathrm{S} / \mathrm{T}] \mathrm{Q}$ site. Perhaps ATM acts as a non-catalytic buffer for nuclear MyRF thus reducing the efficiency of its transcriptional regulation. These two ATM actions might not be mutually exclusive and future work might well explore the possibility that MyRF phosphorylation by ATM controls its nucleocytoplasmic translocation.

Taken together, these findings illustrate that ATM has important functions at various stages in the OL lineage (summarized in Fig. 16). Beginning with the oligodendrocyte precursor (OPC) populations, it is increasing clear that ATM plays an important role as a "guardian of the oligodendrocyte genome"[100]. Failure of this function leads to a block in the OL differentiation program. After OL differentiation has begun, ATM deficiency would appear to be responsible for a region-specific loss of mature OL and their myelin. Hypomyelination is a regular phenotype of syndromes caused by genetic mutations that compromise DNA repair 
medRxiv preprint doi: https://doi.org/10.1101/2021.01.22.20245217; this version posted January $26,2021$. The copyright holder for this

preprint (which was not certified by peer review) is the author/funder, who has granted medRxiv a license to display the preprint in perpetuity.

Tse et al

medRxiv

[57]. Thus, mutations in ATM (Ataxia-telangiectasia [27-31]), NBS1 (Nijmegen Breakage Syndrome [101]), and to a lesser extent the mutation of MRE11 (Ataxia telangiectasia-like disorder [102, 103]) all result in myelin pathology. We note as well that mutations in ERCC2 (excision repair cross-complementation, or XPD) also lead to myelin deficits. As proposed for ATM, ERCC2 has cellular functions in addition DNA repair, in this case serving as an OL transcription factor [104, 105]. Future experiments should focus on the molecular switch of nuclear and cytoplasmic ATM activity during DDR-dependent and DDR-independent functions.

\section{Conclusion}

We confirm that focal destruction of myelinated fibers is a consistent phenotype across cases of A-T caused by any of a dozen different mutations, as found in earlier studies [29]. The timing of the myelin/OL abnormalities and their quantitative relationship to different neuronal phenotypes make it plausible that the myelin defects are not simply a consequence of neuronal loss, but instead reflect cell autonomous effects of ATM deficiency on the oligodendrocyte itself. We demonstrate that the OL is highly vulnerable to loss of ATM activity - both in the nucleus, where it aids in the DNA damage response, and in the cytoplasm, where it aids in the compaction of myelin. This offers multiple pathways by which to explain the hypomyelination phenotype of the A-T brain. Given its classic role as a nuclear protein, our finding that ATM interacts physically with the OL-specific protein, MyRF and MBP is both surprising and enlightening. The specific relationship between the specific ATM mutation and the molecular and cellular details of the myelin pathology remains obscure as does the exact consequence of altered ATM compartmentalization in the OL remains unexplored. We submit that both of these issues are worthy of further investigation.

\section{Acknowledgments}

The present work was generously supported by Health and Medical Research Fund (HMRF06173836 and HMRF04151436) of the Food and Health Bureau, Hong Kong Special Administrative Region, as well as National Institute of Neurological Disorders and Stroke (NINDS) R01NS071022-01. We acknowledge the kind support from the staff at NeuroBioBank of National Institutes of Health (NIH). All frozen human tissue in this study was obtained from the NIH NeuroBioBank at the University of Maryland, Baltimore, MD, and the PPFE tissues from Neuropathology Core, University of Pittsburgh Alzheimer's Disease Research Center, United States. Dr Kofler and Alzheimer's Disease Research Center at the University of Pittsburgh are supported by NIA P30 AG066468 and NIA P50 AG005133. Dr Jiang and the TEM work are supported by AoE/M-05/12. 
medRxiv preprint doi: https://doi.org/10.1101/2021.01.22.20245217; this version posted January $26,2021$. The copyright holder for this

preprint (which was not certified by peer review) is the author/funder, who has granted medRxiv a license to display the preprint in perpetuity.

Tse et al

All rights reserved. No reuse allowed without permission.

medRxiv

\section{Figure Legends}

\section{Figure 1. Loss of cerebellar neurons and OLs in Ataxia Telangiectasia}

a) (i) Immunohistochemistry of Olig2+ shows the density of OLs (nuclei; brown) in cerebellar cortex (Region 1) folial white matter (Region 2) and deep cerebellar nuclei (Region 3). b) Olig2 density is reduced with age in the cerebella of healthy controls. a) (ii) ATM immunostaining (antibody 2C1; brown) is found in the nucleus and cytoplasm of Purkinje cells as well as in cells resembling OL in the myelin tracts and deep cerebella. c) Atrophy of cerebellar neurons in A-T subjects includes reduced number, reduced soma size and dysplasia of Purkinje cells (Green, MAP2, arrowhead). Representative images from age-matching normal control $(\mathrm{n}=10)$ and A-T ( $\mathrm{n}=10)$ subjects. d) Quantifications of Purkinje cell density and size. e, f) Purkinje cell density, but not soma size, is significantly downregulated with age in A-T subjects. g) Upper panel: reduced oligodendrocyte (arrowheads) density was found in the gray matter of cerebellar cortex (cerebellar GM) and white matter (cerebellar WM). Lower panel: cells with Olig2-immunoreactivity (IR) resembling fibrillary astrocytes were identified in A-T but not healthy controls. (open arrowhead). Insets show higher mag of identified cells. h) A reduction of mature myelinating $\mathrm{OL}(\mathrm{CC} 1+)$ and, (i)Massive astrogliosis (GFAP+) in cerebellar GM and $\mathrm{WM}$ in A-T. j-l) There were significant differences between control and A-T in the densities of Olig2 $2^{+} \mathrm{OL}, \mathrm{CC}^{+} \mathrm{mOL}$ and $\mathrm{GFAP}^{+}$astrocyte-IR (unpaired t-test, $\mathrm{n}=10$ ). $\mathbf{m - o}$ ) Changes in OL lineage or astrogliosis were not associated with aging. p-r) However, in healthy controls, but not A-T cases, OL densities (Olig2 ${ }^{+}$) were significantly correlated with Purkinje cell size.

\section{Figure 2. Gene expression profile in A-T cerebellum}

a) Heatmap representing altered gene expression patterns in cerebellar cortices from healthy control (NC; $n=10)$ and A-T $(n=8)$. Changes were found in DNA repair genes as well as glialand myelin-associated genes. b) Neuronal, synaptic and genes of ATM-dependent and independent DNA repair mechanisms were significantly downregulated in A-T. c) Myelin and OL progenitor cell (OPC)-associated genes were significantly upregulated in A-T (MyRF, MBP, MAG, OLIG1, CSPG4, PLP1, SOX10 NKX2.2, CNPASE). Differences tested by unpaired t-tests.

\section{Figure 3. ATM mutation variants and neuropathology in A-T}

a) The position of the mutations found in ten A-T cases are illustrated on a one-dimensional map of the ATM protein structure. b) Mature OL $\left(\mathrm{CC}^{+}\right)$, but not total OL (OLIG2 $\left.{ }^{+}\right)$or reactive astrocyte $\left(\mathrm{GFAP}^{+}\right)$density is significantly reduced in carriers of frameshift mutations c) Density of Purkinje cells is reduced in non-frameshift carriers; Purkinje cell soma were significantly reduced in size in all A-T cases. Frameshift carriers trended towards an earlier age of death $(\mathrm{p}=0.0589)$. d) OL and astrocyte-related gene expression (OLIG2, MyRF, MBP and GFAP) was significantly increased in all A-T subjects (except OLIG2 in frameshift carriers). e) Neuron-related gene expression (RBFOX3, TUBB3, SYN1, SYN2) was significantly reduced without difference between frameshift and non-frameshift cases. All unpaired t-tests $(* \mathrm{p}<0.05, * * \mathrm{p}<0.01, * * * \mathrm{p}<0.001)$.

\section{Figure 4. Myelin abnormalities in Atm-knockout mouse model (Atm-- )}

a) The number of intracortical myelin fibers in the frontal cortex and corpus callosum are reduced in homozygous, but not heterozygous, $\mathrm{Atm}^{-}$mice at 1 month of age (representative images from at least three animals per group). b) Immunoblots of myelin proteins (MAG, MBP, MOG and PLP) in the neocortex and cerebellum of $\mathrm{Atm}^{-/-}$mice (supported by immunohistochemistry - Fig. S1a). c) Quantification of blots in panel b (unpaired t-test vs control; * $\mathrm{p}<0.05 ; * * \mathrm{p}<0.01$ ). The normal distribution of myelin proteins in myelin sheath is indicated in the diagram at the bottom right. d) Transmission electron microscopy confirmed 
medRxiv preprint doi: https://doi.org/10.1101/2021.01.22.20245217; this version posted January $26,2021$. The copyright holder for this preprint (which was not certified by peer review) is the author/funder, who has granted medRxiv a license to display the preprint in All rights reserved. No reuse allowed without permission.

Tse et al

medRxiv

myelin abnormality in the neocortex, corpus callosum and cerebellum of the $\mathrm{Atm}^{-1-}$ mice; e) Left histograms: quantification of axon density (upper panel), diameter (middle panel) and gratio in the three brain regions indicated $(10-14$ fields per region, $n=3)$ similar to those in panel d. Right scatter plots show the variation in g-ratio as a function of axon diameter. f) higher resolution images of representative axons showing the myelin thinning in $\mathrm{Atm}^{-/-}$cortex is shown.

Figure 5. OL survival and synthetic capabilities are age, genotype, and region specific a) Immunohistochemistry of $\mathrm{NG}^{+}$(green) and Olig2 ${ }^{+}$(red) in three regions of the $\mathrm{Atm}^{-{ }_{-}}$mouse brain at 1 month. Arrowheads indicated double positive OPCs b) Quantification of total OL $\left(\mathrm{Olig} 2^{+}\right)$and $\mathrm{NG}^{+} / \mathrm{Olig} 2^{+} \mathrm{OPCs}$ c) Immunohistochemistry of the mature OL $\left(\mathrm{MyRF}^{+} / \mathrm{Olig}^{+}\right.$ double-positive or $\mathrm{CC}^{+}$cells) - arrowheads) in the same brain regions as in panel a. d) Quantifications of $\mathrm{MyRF}^{+} \mathrm{mOL}$ (by $\mathrm{MyRF}^{+} / \mathrm{Olig} 2^{+}$double-positive or $\mathrm{CC}^{+}$immunostaining) in $\mathrm{Atm}^{-/-}$brain at two different ages e) The expression of cell type-specific genes as measured by real time PCR in lysates of neocortex f) Western blots of OL-related proteins and their quantification relative to the loading control, GAPD. g) The same panel of genes was tested by PCR in lysates of cerebellum. h) Western blots of the same OL-related proteins from cerebellar lysates. Statistical significance tested by one-way ANOVA with Newman-Keuls among groups, t-test for pairwise comparison $(* p<0.05, * * p<0.01$, $* * * p<0.001)$. All images are representative from at least three experiments.

Figure 6. DSB-DNA damage in ATM deficiency and contribution of oxidative stress

a, b Immunohistochemistry of cerebellar cortical gray matter (a) and white matter (b) of a healthy control (NC) an A-T case. c) oxidative DNA damage in oligodendrocytes was assessed by the density of Olig2 (red)/8-OHG (8-hydroxyguanosine - cyan) double-labeled cells in wild type and $\mathrm{Atm}^{-/}$neocortex and corpus callosum d) Oligodendrocyte DNA damage was determined by the density of $\mathrm{Olig}^{+}$(red)/53BP1 (green) double-labeled cells (filled arrowheads) in neocortex and corpus callosum. In the neocortex, a large number of cortical neurons were double-positive for 8-OHG and 53BP1 (arrows). e) The inhibition of endogenous ATM activity by KU-60019 $(0.1-10 \mu \mathrm{M}, 24 \mathrm{~h})$ increased the percentage of Oli-Neu cells with nuclear $\gamma \mathrm{H} 2 \mathrm{AX}^{+}$and $53 \mathrm{BP} 1^{+}$foci $(\mathrm{n}=4)$. f) Quantification of the percent of images such as those shown in panel e. Statistical significance tested by one-way ANOVA with NewmanKeuls among groups, or t-test for pairwise comparison $(* p<0.05$, $* * p<0.01$, $* * * p<0.001)$. All images are representative from at least three experiments.

Figure 7. ATM activation and cell cycle activity in OPC

a) ATM immunolabeling (red) was detectable in both nucleus and cytoplasm of cultured NG2 ${ }^{+}$

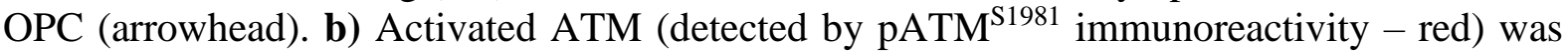
also found in both nucleus and cytoplasm of the cultured OPC. c) The levels of pATM $^{\mathrm{S} 1981}$ autophosphorylation were significantly attenuated by KU-60019 (10 $\mu \mathrm{M}, 24 \mathrm{~h}-$ lower plot) without compromising the cell viability (upper histogram). d) Dose response curves taken at $24 \mathrm{~h}$ for etoposide- and KU-60019-mediated DNA damage $(\mathrm{n}=3)$. e) OPC cell cycle activity (expression of cyclin D1 - CCD1 [red]; cyclin A1 - CCA2 [magenta]) in KU-60019 and etoposide-treated cultures. f) Quantification of the immunocytochemistry results illustrated in panel e $(n=3)$. g) OPC cell cycle activity as measured by Edu incorporation revealed by ClickIT chemistry (cyan) in control cultures as well as in the presence of increasing doses of KU-60019 and etoposide as indicated. h) Quantification of the immunocytochemistry results illustrated in panel $\mathrm{g}(n=4)$. (*One-way ANOVA vs control, " two-way ANOVA KU-60019 vs etoposide). (* or ${ }^{\#} p<0.05, * *$ or ${ }^{\# \#} p<0.01$, *** or $\left.{ }^{\# \# \#} p<0.001\right)$.

Figure 8. ATM activation and cell cycle activity in mature $O L$

a) ATM immunoreactivity (red, arrowhead) was found in the nucleus and cytoplasm of $\mathrm{MBP}^{+}$ 
medRxiv preprint doi: https://doi.org/10.1101/2021.01.22.20245217; this version posted January $26,2021$. The copyright holder for this preprint (which was not certified by peer review) is the author/funder, who has granted medRxiv a license to display the preprint in perpetuity.

Tse et al

All rights reserved. No reuse allowed without permission.

medRxiv

mOL (green) b) Activated ATM, denoted by immunostaining for $\mathrm{pATM}^{\mathrm{S} 1981}$ (red) was also detected in both the nucleus and cytoplasm of the mOL. pATM ${ }^{\mathrm{S1} 1981}$ was found in the soma (right column, open arrowheads) and cytoplasmic processes (closed arrowheads). All

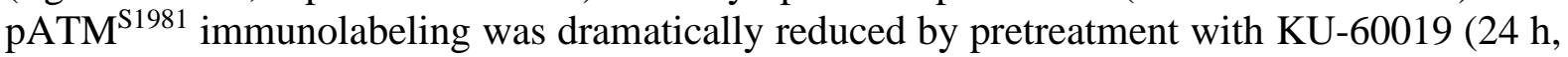
$10 \mu \mathrm{M})$. c) Quantification of images similar to those shown in panel b. d) Cell cycle activity in mature OLs $\left(\mathrm{MBP}^{+}\right)$and OPCs in culture at DIV7 as measured by immunolabeling for cyclins D1 and A2. e) Quantification of images similar to those shown in panel d. f, g) Effects of $24 \mathrm{~h}$ treatment of KU-60019 and etoposide on mature OL and cortical neurons as assessed by f) cell number and g) cell cycle activity (immunolabeling for cyclin D1). Statistical analysis: *Oneway ANOVA vs control, "two-way ANOVA mOL vs neuron $(n=3-4)$. $\left({ }^{*}\right.$ or ${ }^{\#} p<0.05$, ** or ${ }^{\#} p<0.01, * * *$ or $\left.{ }^{\# \#} p<0.001\right)$. All representative images from at least three experiments.

Figure 9. Aberrant cell cycle re-entry is associated with $\mathrm{mOL}$ cell death

a Confocal images of cultured $\mathrm{mOL}\left(\mathrm{MBP}^{+}\right.$green) pretreated for $24 \mathrm{~h}$ with $\mathrm{KU}-60019$ (10 $\mu \mathrm{M}), \mathrm{H}_{2} \mathrm{O}_{2}(50 \mu \mathrm{M})$ and etoposide $(10 \mu \mathrm{M})$. Cell cycle activity was measured by immunolabelling for cyclin D1 (red); cell death was measured by the presence of cleaved caspase-3 (CC3, magenta). b) Quantification of the percentage of cycling mOLs (MBP/cyclinD1 double positive). c) Quantification of the percentage of dying mOLs (MBP/CC3 double positive) d) Quantification of the percentage of mOLs dying a cell cycle related death (MBP/CC3/cyclin D1 triple positive). e) effects of the three treatments on overall $\mathrm{mOL}$ survival $\left(\mathrm{MBP}^{+}\right.$cells per field, expressed as a percentage of untreated control cultures. f) Cell cycle activity as assessed by cyclin $\mathrm{D}$ (red) in $\mathrm{mOL}\left(\mathrm{CC}^{+}-\right.$green) in three different brain regions of $\mathrm{Atm}^{-/-}$mice at 1 month of age $\left(\mathrm{CC}^{+} /\right.$cyclin $\mathrm{D} 1^{+}$, open arrowhead; $\mathrm{CC}^{+}$only, white arrowhead; cyclin $\mathrm{D} 1^{+}$only, open arrows). g) Quantifications of fields similar to those shown in panel $\mathrm{f}$ at two ages ( 1 and 6 months). h) Cell cycle activity actively as assessed by cyclin D immunoreactivity (red) in actively myelinating $\mathrm{mOL}$ as assessed by MyRF immunoreactivity (green) in three different brain regions of $\mathrm{Atm}^{-/-}$mice at 1 month of age. $\left(\mathrm{MyRF}^{+} /\right.$cyclin $\mathrm{D}^{+}$, open arrowhead; $\mathrm{MyRF}^{+}$only, white arrowhead; cyclin $\mathrm{D} 1^{+}$only, open arrows). i) Quantifications of fields similar to those shown in panel $f$ at two ages ( 1 and 6 months). Statistical analysis by one-way ANOVA with Newman-Keuls among groups, or ttest for pairwise comparison $(* p<0.05$, ** $p<0.01$, *** $p<0.001$ ).

Figure 10. Aberrant cell cycle progression in $\mathrm{mOL}$ is controlled by ATM

a) Confocal image of aberrant cell cycle events induced by etoposide or OL-specific growth factors (PDGF-AA and bFGF, $2 \mathrm{ng} / \mathrm{mL}$ ) in DIV14 OL primary cultures (yellow, cyclin D1; red, $\gamma \mathrm{H} 2 \mathrm{AX}$; green, MBP). b) EdU incorporation and cyclin A2 immunocytochemistry showing the abnormal re-entry of mOL into the G1/S transition phase of the cell cycle. c-i) Quantification of immunocytochemistry imaging reveals the percentage of $\mathrm{mOL}\left(\mathrm{MBP}^{+}\right)$that transition to cell cycle or cell death activity after treatment with etoposide $(10 \mu \mathrm{M})$, growth factors (PDGF-AA and bFGF, $2 \mathrm{ng} / \mathrm{mL}$ ) or KU-60019 $(10 \mu \mathrm{M})$ : cell cycle as assessed by $\mathrm{MBP}^{+}$ cells that also express c) cyclin D1; d) cyclin A2; or e) EdU incorporation. Cell death was measured by the percentage of $\mathrm{MBP}^{+}$cells that also express f) cleaved caspase- 3 (CC3) at 24 and $72 \mathrm{~h}$ after addition of drug. g-i) The effects of ATM activity on aberrant cell cycle re-entry and cell death as seen by the percentage of $\mathrm{mOL}\left(\mathrm{MBP}^{+}\right)$that are positive for $\mathbf{g}$ ) cyclin D1 $\mathbf{h}$ ) cycle-related apoptosis as assessed by MBP/CC3 double labeled cells. i) total cell death $\left(\mathrm{CC}^{+}\right)$. Statistical analysis by one-way ANOVA with Newman-Keuls among groups, or t-test for pairwise comparison $(* p<0.05, * * p<0.01, * * * p<0.001, \mathrm{n}=4)$.

Figure 11. Endogenous ATM activity inhibition attenuates OL differentiation

a) Confocal microscopic images show that OPC induced to differentiate in vitro have activated ATM (pATM ${ }^{\mathrm{S} 1981}$ ) immunoreactivity (red) in both nucleus and cytoplasm in newly formed OLs expressing MBP (green). a(i) Higher magnification of the area indicated by the white box in 
medRxiv preprint doi: https://doi.org/10.1101/2021.01.22.20245217; this version posted January 26, 2021. The copyright holder for this preprint (which was not certified by peer review) is the author/funder, who has granted medRxiv a license to display the preprint in All rights reserved. No reuse allowed without permission.

Tse et al

medRxiv

panel a. a(ii), a(iii) Enlargement of the area indicated by the white arrowheads in $\mathbf{a ( i ) . ~ b ) ~ W e l l - ~}$ established mOLs have pATM $^{\mathrm{S} 1981}$ immunoreactivity remaining in the nucleus (open arrowhead) and $\mathbf{b}(\mathbf{i})$ Higher magnification of the area indicated by the white box in panel $b$ showing the cytoplasmic processes (white arrowhead) with pATM $^{\mathrm{S} 1981}$ immunolabeling. b(ii), b(iii) Enlargement of the area indicated by the white arrowheads in b(i). MBP immunoreactivity was found adjacent to the ATM-positive major branch but was not colocalization (closed arrowheads). c) Schematic diagram of the experimental approach testing the role of ATM during OPC differentiation to mOL. d) left Dose-response curve of KU-60019 shows the suppression of differentiation of $\mathrm{OPC}$ into $\mathrm{MBP}^{+}$and $\mathrm{MAG}^{+} \mathrm{mOL}$ at DIV7; right KU-60019 also suppressed total OL cell number $\left(\right.$ Olig2 ${ }^{+}$) and actively myelinating OL $\left(\mathrm{MyRF}^{+}\right)$. e) Confocal images showing nuclear MyRF levels in $\mathrm{mOL}$ after chronic incubation with KU-60019 $(1 \mu \mathrm{M})$. f) Effects of KU-60019 $(1 \mu \mathrm{M})$ on the expression of oligodendrocyte and astrocyte-related genes as assessed by real-time PCR. g) The effect of KU-60019 on the intensity of Olig2 immunoreactivity in OPC cell nuclei h) Immunocytochemistry of Oli-Neu differentiated with cAMP in the presence or absence of KU-60019 (added prior to cAMP). i) changes in levels of Oli-Neu Mag message with time after cAMP stimulation of differentiation. j) Changes in Oli-Neu Mag message levels 3 days after differentiation with cAMP in the presence or absence of KU-60019. k) Changes in Oli-Neu MAG protein levels 3 days after differentiation with cAMP in the presence or absence of KU-60019. I) Effects of the knockdown of Atm or Atr on MyRF immunoreactivity in Oli-Neu cells. m) Effects of the knockdown of Atm or Atr on MAG immunoreactivity in Oli-Neu cells. Statistical analysis by one-way ANOVA with Newman-Keuls among groups, or t-test for pairwise comparison $\left({ }^{*} p\right.$ $<0.05, * * p<0.01, * * * p<0.001, \mathrm{n}=3-4)$.

Figure 12. Phosphorylation of S/TQ motifs in brain lysate of Atm ${ }^{-1}$ mouse colony

a) Immunoblot showing the phosphorylated $[\mathrm{S} / \mathrm{T}] \mathrm{Q}$ motifs $(\mathrm{p}[\mathrm{S} / \mathrm{T}] \mathrm{Q})$ in cortical tissues from wildtype, heterozygous and homozygous $\mathrm{Atm}^{-/-}$mice. b Immunoblot quantifications. Statistical analysis by one-way ANOVA with Newman-Keuls among groups, $(* p<0.05, \mathrm{n}=3) \mathbf{c}$, d) $\mathrm{p}[\mathrm{S} / \mathrm{T}] \mathrm{Q}$ blot of immunoprecipitation (IP) of MBP from mouse brain lysates. e, f) $\mathrm{p}[\mathrm{S} / \mathrm{T}] \mathrm{Q}$ blot of immunoprecipitation (IP) of MyRF from mouse brain lysates.

\section{Figure 13. Myelin basic protein as a potential phosphorylation target of ATM}

a) Protein structure of mouse myelin basic protein (NP_001020422.1) with [S/T]Q sites in this 195 amino acid peptide indicated in red. The highly conserved central fragment (S99 to S134) is highlighted in green. b) Left: Docking model of human ATM (PDB: 5NP0, grey) and the high conserved central MBP fragment shown in a (PDB: 2LUG, green). Right The probable protein-protein interaction model between human ATM (navy, mesh skin) and mouse MBP (yellow, sticks and balls) showing the MBP docking site within the spiral and pincer region of ATM. The location of the MBP fragment within ATM is indicated in the clipped open box. c) Flipped image of the 3D model showing the close proximity (14.98 $\AA$ ) between [S/T]Q sites (Q100, Q105 and Q127) of MBP. c(i) Q100 of MBP forms a putative $1.83 \AA$ hydrogen bond with K1387 of ATM (contact area $=28.46 \AA^{2}$; labelled yellow on mesh contour) c(ii) Q105 of MBP forms a putative $1.89 \AA$ hydrogen bond with H448 of ATM (contact area $=27.1 \AA^{2}$; labelled yellow on mesh contour). The adjacent D106 of MBP also forms two putative hydrogen bonds with R451 of ATM (lengths $=1.89-1.92 \mathrm{~A}$ ).

Figure 14. Myelin regulatory factor as a potential phosphorylation target of ATM

a) Protein structure of mouse myelin regulatory factor (NP_001028653.1) with the $[\mathrm{S} / \mathrm{T}] \mathrm{Q}$ domain annotated in red. The N-terminus of MyRF contains a Ndt80-like DNA binding domain necessary for nuclear translocation and myelin gene transcription (green, PDB:5H5P). Three [S/T]Q domains are indicated containing a total of 13 separate SQ or TQ sites (indicated in red). b) Left: Docking model of human ATM (PDB: 5NP0, grey) and the MyRF DNA-binding 
medRxiv preprint doi: https://doi.org/10.1101/2021.01.22.20245217; this version posted January 26, 2021. The copyright holder for this preprint (which was not certified by peer review) is the author/funder, who has granted medRxiv a license to display the preprint in All rights reserved. No reuse allowed without permission.

Tse et al

medRxiv

domain a (PDB: 5H5P, green). Right A probable protein-protein interaction model between mouse MyRF (yellow, ribbons with secondary structures) and human ATM at the pincer region (navy, mesh skin). c) enlargement of the region of interaction between MyRF and ATM, with the single [S/T]Q site (S450 Q451) highlighted in red. Putative hydrogen bonds are illustrated for the areas indicated by arrows labeled 1 and 2. c(i) In area 1, situated lateral to the ATM pincer region, at least six hydrogen bonds could form, including E525(Y1252, 2 H-bonds 1.92 A), Q522 (V1292 \& V509, 2 H-bonds 2.02-2.08 A ) N359 (N1240, 1 H-bond. $1.94 \AA$ ), L438 (V1292 \& V509, 2 H-bonds, 2.02-2.08 ̊ =), K437 (R1249, 1 H-bonds, 1.89), L441 (R1249 \& Y1248, 2 H-bonds, 1.90-2.03 А). c(ii) In area 2 situated medial to the ATM pincer region, at least seven hydrogen bonds could form., including S388 (S1799, 1 H-bonds, $1.84 \AA$ ), G390 (S1799, 1 H-bonds, $1.92 \AA$ ), R490 (E1800, 1 H-bonds, $1.87 \AA$ ), G493 (N1801, 1 H-bonds, $1.92 \AA$ ), K491(D1803, 1 H-bonds, $1.70 \AA$ A), K494 (D1848, 1 H-bonds, $1.75 \AA$ ), K492 (E1832, 2 H-bonds, 1.77-1.88 ̊).

Figure 15. Structural changes in the spiral or pincer regions compromise ATM-myelin protein and correlate with oligodendrocyte pathology

a) The docking scores $\left(E_{\text {balanced }} \mathrm{KJ} \mathrm{mol}^{-1}\right.$ ) between ATM (PDB:5NP0A) and known ATM substrates (PDB as noted) or myelin-related protein of human or mouse origin plotted against the ATM mutation site [76] b) Three major regions of ATM are highlighted: the N-terminal spiral region (blue), the central pincer region (yellow) and the FAT-kinase domain near the Cterminus (cyan) c, d) The predicted binding sites between mouse c) MBP (yellow PDB:2LUG) or d) MyRF-DBD (yellow, PDB:5H5P) and human ATM (navy, 5NP0 A) or ATM mutant $\mathrm{R} 2443 \mathrm{del}$ or L315Y. The probable binding site is lost in the L315Y mutant, which impacts the spiral-pincer regions. The corresponding binding scores are shown at bottom of each model. The lost structure of native ATM (5NP0) was superimposed as the green thin ribbon in each docking model. e) The binding scores between ATM mutants and different potential targets including 53BP1 (a known ATM substrate), MBP, MyRF or PMP2. The bars represent the average scores of mutations that terminate the ATM protein early at the spiral-pincer region $(\leq 1238)$ or later at the FAT-Kinase domain $(\geq 2032)$. For reference, the score of the wild type protein (red square). (Unpaired t-tests). f) Comparison of the density of total OLs (Olig2 $2^{+}$, mature OLs $\left(\mathrm{CCl}^{+}\right)$, reactive astrocytes $\left(\mathrm{GFAP}^{+}\right)$, Purkinje cell number and soma size between subjects with early $(\leq 1238)$ or late $(\geq 2032)$ truncated ATM mutants. (Unpaired t-test one-tail). g) Purkinje soma size as a function of docking affinity (increased $E_{\text {balanced}}$ ) of site of ATM mutation and known ATM substrates - 53BP1-P53 complex (left) or myelin protein (right). Pearson test.

Figure 16. Multifaceted functions of ATM in OL life cycle

Diagram of the various roles of ATM during OPC self-renewal, OL differentiation and postmitotic cell cycle control. Also indicated are the effects of the chronic accumulation of oxidative stress as well as unrepaired DNA breaks. We propose that the cell-intrinsic molecular pathology of the OL lineage is the root cause of the early and widespread myelin abnormality of the A-T central nervous system.

Figure S1. Age- and genotype-associated neuropathology in Atm ${ }^{-1-}$ mice

a) Representative images of immunohistochemistry of myelin proteins (MAG, MBP, MOG and PLP) in the cortex, corpus callosum and cerebellum of wildtype and $\mathrm{Atm}^{-/-}$) b, c) Early neuronal pathology in form of aberrant re-expression of the cell cycle-related protein, cyclin D1 (red) in post-mitotic neurons (MAP2 ${ }^{+}$, green) of $\mathrm{Atm}^{-/-}$mice (arrowheads). d) Quantification of images such as those shown in panels $b$ and c. e, f) Western blots of the neuronal markers $\mathrm{NeuN}, \mathrm{Cux} 2$ and ROR $\alpha$ as well as the synaptic marker (Syn1) in brain lysates of $\mathrm{Atm}^{-/-}$mice at 1 month of age. (All unpaired t-test vs control $n=3$ ). 
medRxiv preprint doi: https://doi.org/10.1101/2021.01.22.20245217; this version posted January 26, 2021. The copyright holder for this preprint (which was not certified by peer review) is the author/funder, who has granted medRxiv a license to display the preprint in All rights reserved.

Tse et al

medRxiv

Figure S2. ATM activation after DSBs or $\mathrm{H}_{2} \mathrm{O}_{2}$ are detrimental to OPC but promote astrogliosis

a, b) Single-strand break (SSB)-inducing agent camptothecin (CPT, $10 \mu \mathrm{M}, 24 \mathrm{~h}$ ) or DSBinducing agent etoposide (Etop, $10 \mu \mathrm{M}, 24 \mathrm{~h}$ ) triggered the formation of nuclear $\gamma \mathrm{H} 2 \mathrm{AX}^{+} \mathrm{DSB}$ foci and reduced $\mathrm{CNP}^{+}$Oli-Neu cell density in a concentration-dependent fashion $(n=4)$. c, d) $\mathrm{H}_{2} \mathrm{O}_{2}$-induced oxidative stress also triggered the formation of $\gamma \mathrm{H} 2 \mathrm{AX}^{+}$and $53 \mathrm{BP} 1^{+} \mathrm{DSB}$ foci in Oli-Neu in a concentration-dependent fashion $(n=4)$. Primary OPC cultures were treated wtih etoposide (Etop, $10 \mu \mathrm{M}, 24 \mathrm{~h})$ and $\left(\mathrm{H}_{2} \mathrm{O}_{2}, 50 \mu \mathrm{M}, 24 \mathrm{~h}\right)$ then assayed for e) total surviving OPC, DNA damage $\left(\gamma-\mathrm{H}_{2} \mathrm{AX}^{+}\right)$and total OL lineage similarly elicited the formation of $53 \mathrm{BP} 1^{+} \mathrm{DSB}$ nuclear foci and reduced cell density of $\mathrm{NG} 2^{+} \mathrm{Olig} 2^{+}$population. f) Immunolabeling for $\gamma-\mathrm{H} 2 \mathrm{AX}$ after the two treatments. g) Etop and $\mathrm{H}_{2} \mathrm{O}_{2}$, also triggers the activation of ATM (pATM $\left.{ }^{\mathrm{S} 1981}\right)$. h) Primary OPC cultures were treated with Etop and $\mathrm{H}_{2} \mathrm{O}_{2}$ in the presence or absence of pre-treatment with KU-60019 (10 $\mu \mathrm{M}, 30 \mathrm{~min})$. i) Oli-Neu cell cultures treated with Etop and $\mathrm{H}_{2} \mathrm{O}_{2}$ in the presence or absence of pre-treatment with KU-60019 $(10 \mu \mathrm{M}, 30 \mathrm{~min})$. j) Similarly, the $\mathrm{H}_{2} \mathrm{O}_{2}$-induced reduction of $\mathrm{NG}^{+}$OPC was prevented by KU-60019 pre-treatment. k) Etoposide and $\mathrm{H}_{2} \mathrm{O}_{2}$ significantly increased the GFAP ${ }^{+}$astrocyte density in primary OPC cultures, and this astrogliosis event was attenuated by the pre-treatment with KU-60019. (* $p<0.05$, ** $p<0.01$, *** $p<0.001$, one-way ANOVA for group comparison, unpaired t-test for pairwise comparison, $n=3-5$ ).

Figure S3. Structural modeling of clinical ATM variants based on human ATM template PDB:5NPO

All the ATM mutants and native ATM (PDB:5NP0 A) modeled by Phyre $^{2}$ server are shown. These models were viewed as a superimposed image between native ATM 5NP0A (thin green ribbon skeleton) with the space-filled model of the mutant variants superimposed with full coloring. Mutants including R248del, L315Y, C430del, E5221, L762V, T1029N, RL1238K, R2032K, R2136del, T1029N, D2525Q, N2679S and W2960del are shown in four rotations. The native ATM 5NP0A in space-filled model with CPK coloring is shown in the box at right bottom. The color codes for the amino acid residues is denoted in the grey figure legend. 


\begin{tabular}{|c|c|c|c|c|c|c|c|c|c|c|}
\hline Case & Chromosome & Coordinate & HGVSc & Exonic & $\begin{array}{l}\text { Read } \\
\text { Depth }\end{array}$ & $\begin{array}{r}\text { HGVSp } \\
\text { NP_000042.3: }\end{array}$ & Type & Mutation type & $\begin{array}{l}\text { Protien } \\
\text { position }\end{array}$ & $\begin{array}{l}\text { Domain } \\
\text { affected }\end{array}$ \\
\hline AT1 & 11 & 108153564 & NM_000051.3:c.3712_3716delTTATT & yes & 367 & p.Leu1238LysfsTer6 & deletion & frameshift_variant & 1238 & $\mathrm{~N}$-terminal \\
\hline AT2 & 11 & 108203575 & NM_000051.3:c.7875T>G & yes & 447 & $\begin{array}{l}\text { NP_000042.3: } \\
\text { p.Asp2625Glu }\end{array}$ & snv & missense_variant & 2625 & FAT/Kinase \\
\hline АT3 & 11 & 108128238 & NM_000051.3:c.2284_2285delCT & yes & 198 & $\begin{array}{l}\text { NP_000042.3: } \\
\text { p.Leu762ValfsTer2 }\end{array}$ & deletion & frameshift_variant & 762 & $\mathrm{~N}$-terminal \\
\hline AT4 & 11 & 108235838 & NM_000051.3:c.8880G>A & yes & 241 & $\begin{array}{l}\text { NP_000042.3: } \\
\text { p.Trp2960Ter }\end{array}$ & snv & stop_gained & 2960 & Kinase \\
\hline AT5 & 11 & 108121752 & NM_000051.3:c.944delT & yes & 58 & $\begin{array}{l}\text { NP_000042.3: } \\
\text { p.Leu315TyrfsTer5 } \\
\text { NP_000042.3: }\end{array}$ & deletion & frameshift_variant & 315 & $\mathrm{~N}$-terminal \\
\hline & 11 & 108117731 & NM_000051.3:c.1564_1565delGA & yes & 281 & p.Glu522IlefsTer43 & deletion & frameshift_variant & 522 & $\mathrm{~N}$-terminal \\
\hline AT6 & 11 & 108143264 & NM_000051.3:c.3085dupA & yes & 404 & $\begin{array}{l}\text { NP_000042.3: } \\
\text { p.Thr1029AsnfsTer1 } \\
9 \\
\text { NP_000042.3: }\end{array}$ & insertion & frameshift_variant & 1029 & $\mathrm{~N}$-terminal \\
\hline AT7 & 11 & 108190736 & NM_000051.3:c.6404_6405insTT & yes & 325 & $\begin{array}{l}\text { NP_000042.3: } \\
\text { p.Arg2136Ter }\end{array}$ & insertion & frameshift_variant & 2136 & FAT \\
\hline AT8 & 11 & 108121479 & NM_000051.3:c.1290_1291delTG & yes & 46 & NP_000042.3: & deletion & frameshift_variant & 430 & $\mathrm{~N}$-terminal \\
\hline AT9 & 11 & 108205719 & $\begin{array}{l}\text { NM_000051.3:c.6404_6405insTT } \\
\text { NM_000051.3: } \\
\text { c.8036_8051 } \\
\text { deIATCTGGTGACTATACA }\end{array}$ & yes & 313 & $\begin{array}{l}\text { NP_000042.3: } \\
\text { p.Arg2136Ter } \\
\text { NP_000042.3: } \\
\text { p.Asn2679SerfsTer9 }\end{array}$ & $\begin{array}{l}\text { insertion } \\
\text { deletion }\end{array}$ & $\begin{array}{l}\text { frameshift_variant } \\
\text { frameshift variant }\end{array}$ & $\begin{array}{l}2136 \\
2679\end{array}$ & $\begin{array}{l}\text { FAT } \\
\text { FAT/Kinase }\end{array}$ \\
\hline AT10 & 11 & 108115594 & NM_000051.3:c.742C>T & yes & 562 & $\begin{array}{l}\text { NP_000042.3: } \\
\text { p.Arg248Ter } \\
\text { NP_000042.3: }\end{array}$ & snv & $\begin{array}{l}\text { stop_gained } \\
\text { missense_variant,splic }\end{array}$ & 248 & $\mathrm{~N}$-terminal \\
\hline & 11 & 108186638 & NM_000051.3:c.6095G>A & yes & 359 & p.Arg2032Lys & snv & e_region_variant & 2032 & FAT \\
\hline
\end{tabular}

Table 1. Genetic details of ATM mutations in A-T subjects based on TruSight- inherited disease panel 


\begin{tabular}{|c|c|c|c|c|c|c|c|c|}
\hline & Name (all from Mus musculus) & Abbreviation & NCBI & $\begin{array}{c}\text { No. of } S / T Q \\
\text { sites }\end{array}$ & $\begin{array}{c}\text { S/TQ site } \\
\text { density }\end{array}$ & $\begin{array}{l}\text { Strongest } \\
\text { S/TQ sites }\end{array}$ & $\begin{array}{c}\text { No. SCD } \\
(\geq 3 / 100 \text { a.a. })\end{array}$ & $\begin{array}{l}\text { Total Length } \\
\text { (a.a.) }\end{array}$ \\
\hline \multirow{4}{*}{ 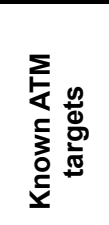 } & Serine/threonine-protein kinase Chk2 & Chk2 & NP_057890.1 & 8 & $8 / 501$ & $6 / 39$ & 4 & 546 \\
\hline & Breast cancer type 1 susceptibility protein homolog & Brca1 & NP_033894.3 & 21 & $21 / 1424$ & $3 / 32$ & 9 & 1812 \\
\hline & Cellular tumor antigen $p 53$ & Tp53 & NP_035770.2 & 4 & $4 / 158$ & $3 / 91$ & 1 & 390 \\
\hline & TP53-binding protein 1 isoform a & 53bp1 & NP_038763.3 & 29 & $29 / 1931$ & $3 / 13$ & 8 & 1969 \\
\hline \multirow{4}{*}{ 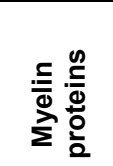 } & Myelin basic protein isoform 1 & MBP & NP_001020422.1 & 5 & $5 / 125$ & $3 / 29$ & 2 & 195 \\
\hline & Myelin-associated glycoprotein isoform 1 precursor & Mag & NP_-001333013.1 & 5 & $5 / 458$ & $4 / 187$ & 0 & 627 \\
\hline & Oligodendrocyte-myelin glycoprotein precursor & Mog & NP_062282.2 & 2 & $2 / 118$ & $2 / 118$ & 0 & 443 \\
\hline & Myelin proteolipid protein isoform 1 & Plp & NP_035253.1 & 0 & N.A & N.A & 0 & 277 \\
\hline \multirow{3}{*}{ 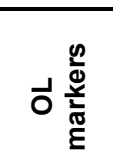 } & Chondroitin sulfate proteoglycan 4 precursor & Cspg4 (Marker NG2) & NP_034053.2 & 27 & $27 / 2063$ & $3 / 40$ & 7 & 2327 \\
\hline & Adenomatous polyposis coli protein & Apc (Marker CC1) & NP_031488.2 & 24 & $24 / 2569$ & $3 / 55$ & 7 & 2842 \\
\hline & 2',3'-cyclic-nucleotide 3'-phosphodiesterase isoform 2 & Cnpase & NP_034053.2 & 1 & N.A & N.A & 0 & 420 \\
\hline \multirow{8}{*}{ 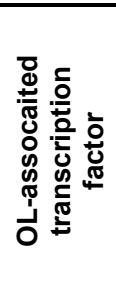 } & Myelin regulatory factor & Myrf & NP_001028653.1 & 13 & $13 / 831$ & $3 / 22$ & 5 & 1112 \\
\hline & Myelin transcription factor 1 isoform 1 & Myt1 & NP_032691.2 & 6 & $6 / 835$ & $2 / 21$ & 0 & 1127 \\
\hline & Transcription factor Sox 10 & Sox10 & NP_035567.1 & 3 & $3 / 356$ & $2 / 57$ & 0 & 466 \\
\hline & Homeobox protein Nkx-2.2 isoform 1 & Nkx2.2 & NP_035049.1 & 2 & $2 / 54$ & $2 / 54$ & 0 & 273 \\
\hline & Homeobox protein Nkx-6.2 & Nkx6.2 & NP_899071.2 & 1 & N.A & N.A & 0 & 277 \\
\hline & Oligodendrocyte transcription factor 1 & Olig1 & NP_058664.2 & 1 & N.A & N.A & 0 & 260 \\
\hline & Oligodendrocyte transcription factor 2 & Olig2 & NP_058663.2 & 0 & N.A & N.A & 0 & 323 \\
\hline & Transcriptional repressor protein YY1 & Yy1 & NP_033563.2 & 1 & N.A & N.A & 0 & 414 \\
\hline
\end{tabular}

Table 2. List of S/TQ sites concentration of known ATM targets, myelin proteins, OL markers and OL-associated transcription factors 


\begin{tabular}{|c|c|c|c|c|c|c|}
\hline Case & Age Range & Brain weight (g) & Gender & Group & PMI (hours) & $\begin{array}{l}\text { RNA intergrity } \\
\text { Number }\end{array}$ \\
\hline NC-Age1 & $80-85$ & N.D. & $\mathrm{M}$ & Ageing-Control & 5 & N.D. \\
\hline NC-Age2 & $70-75$ & N.D. & $\mathrm{M}$ & Ageing-Control & 3 & N.D. \\
\hline NC-Age3 & $85-90$ & N.D. & $\mathrm{M}$ & Ageing-Control & 7 & N.D. \\
\hline NC-Age4 & $60-65$ & N.D. & $\mathrm{m}$ & Ageing-Control & 6.5 & N.D. \\
\hline NC-Age5 & $75-80$ & N.D. & $M$ & Ageing-Control & 6 & N.D. \\
\hline NC-Age6 & $75-80$ & N.D. & $\mathrm{F}$ & Ageing-Control & 10.5 & N.D. \\
\hline NC-Age7 & $70-75$ & N.D. & $\mathrm{F}$ & Ageing-Control & 4.5 & N.D. \\
\hline NC-Age8 & $85-90$ & N.D. & $M$ & Ageing-Control & 4 & N.D. \\
\hline NC-Age9 & $75-80$ & N.D. & $M$ & Ageing-Control & 14 & N.D. \\
\hline NC1 & $10-20$ & 1600 & $\mathrm{M}$ & Control & 33 & 6.1 \\
\hline NC2 & $10-20$ & 1660 & $\mathrm{M}$ & Control & 18 & 8.9 \\
\hline NC3 & $20-25$ & N.D. & $\mathrm{M}$ & Control & 14 & 6.7 \\
\hline NC4 & $30-35$ & 1550 & $\mathrm{M}$ & Control & 16 & 7.4 \\
\hline NC5 & $20-25$ & 1160 & $\mathrm{~F}$ & Control & 14 & 8 \\
\hline NC6 & $30-35$ & 1800 & $M$ & Control & 27 & 7.5 \\
\hline NC7 & $15-20$ & 1400 & $\mathrm{~F}$ & Control & 5 & N.D. \\
\hline NC8 & $25-30$ & 1240 & $\mathrm{~F}$ & Control & 11 & 7 \\
\hline NC9 & $25-30$ & 1530 & $\mathrm{M}$ & Control & 12 & 7.1 \\
\hline NC10 & $15-20$ & 1350 & $\mathrm{~F}$ & Control & 16 & 9.2 \\
\hline AT1 & $25-30$ & 1410 & $\mathrm{~F}$ & Ataxia Telangiectasia & 4 & N.D. \\
\hline AT2 & $30-35$ & 1565 & $\mathrm{M}$ & Ataxia Telangiectasia & 13 & N.D. \\
\hline AT3 & $15-20$ & 1153 & $\mathrm{~F}$ & Ataxia Telangiectasia & 2 & N.D. \\
\hline AT4 & $20-25$ & 980 & $\mathrm{~F}$ & Ataxia Telangiectasia & 2 & N.D. \\
\hline AT5 & $15-20$ & 1400 & $\mathrm{M}$ & Ataxia Telangiectasia & 15 & N.D. \\
\hline AT6 & $25-30$ & 1380 & $\mathrm{M}$ & Ataxia Telangiectasia & 7 & N.D. \\
\hline AT7 & $25-30$ & N.D. & $\mathrm{F}$ & Ataxia Telangiectasia & 3 & 6.5 \\
\hline AT8 & $20-25$ & 1370 & $M$ & Ataxia Telangiectasia & 15 & 7 \\
\hline AT9 & $25-30$ & 1572 & $\mathrm{M}$ & Ataxia Telangiectasia & 14 & 8.4 \\
\hline AT10 & $35-40$ & 1180 & $\mathrm{M}$ & Ataxia Telangiectasia & 20 & N.D. \\
\hline
\end{tabular}

Table S1. Demographic details of postmortem human cases in this study 
medRxiv preprint doi: https://doi.org/10.1101/2021.01.22.20245217; this version posted January 26,2021 . The copyright holder for this preprint (which was not certified by peer review) is the author/funder, who has granted medRxiv a license to display the preprint in perpetuity.

All rights reserved. No reuse allowed without permission.

\begin{tabular}{|c|c|c|c|c|c|}
\hline Antibody & Host \& Clonality & Target & $\begin{array}{l}\text { Application } \\
\text { \& dilution }\end{array}$ & Manufacturer & Cat No. (Clone) \\
\hline 53BP1 & Rabbit Polyclonal & $\begin{array}{l}\text { Marker of double strand } \\
\text { breaks (DSB) damage in the } \\
\text { nucleus }\end{array}$ & ICC: 1250 & Abcam & ab36823 (N/A) \\
\hline 8-OHdG & Goat polyclonal & $\begin{array}{l}\text { Marker of oxidative DNA } \\
\text { lesion in the nucleus }\end{array}$ & IHC: $1: 250$ & $\begin{array}{l}\text { EMD } \\
\text { Millipore }\end{array}$ & AB5830 (N/A) \\
\hline APC & Mouse monoclonal & $\begin{array}{l}\text { Mature OL marker } \\
\text { (commonly known as CC1) }\end{array}$ & IHC: $1: 500$ & Millipore & $\begin{array}{l}\text { MABC200 } \\
(\mathrm{CC} 1)\end{array}$ \\
\hline ATM & Mouse monoclonal & $\begin{array}{l}\text { Ataxia telangiectasia mutated } \\
\text { DSB repair protein }\end{array}$ & $\begin{array}{l}\text { IHC: } 1: 500 \\
\text { ICC: } 1: 250\end{array}$ & Abcam & $\mathrm{ab} 78(2 \mathrm{C} 1)$ \\
\hline $\begin{array}{l}\text { Cleaved } \\
\text { Caspase } 3\end{array}$ & Mouse monoclonal & Apoptotic cells & IHC: $1: 250$ & $\begin{array}{l}\text { EMD } \\
\text { Millipore }\end{array}$ & $\begin{array}{l}\text { MAB10753 } \\
\text { (3D9.3) }\end{array}$ \\
\hline Cux2 & Rabbit polyclonal & $\begin{array}{l}\text { Marker for cortical neurons } \\
\text { layer II-IIII }\end{array}$ & WB 1:1000 & Abcam & ab130395 \\
\hline Cyclin A2 & Rabbit Monoclonal & Marker of G1/S transition & ICC: $1: 250$ & Abcam & $\begin{array}{l}\text { ab181591 } \\
\text { (EPR17351) }\end{array}$ \\
\hline Cyclin D1 & Mouse monoclonal & $\begin{array}{l}\text { A marker for G1/S phase } \\
\text { transition during cell cycle }\end{array}$ & $\begin{array}{l}\text { IHC: } 1: 250 \\
\text { ICC: } 1: 250 \\
\end{array}$ & Santa Cruz & sc-450 (72-13G) \\
\hline Cyclin D1 & Rabbit polyclonal & $\begin{array}{l}\text { A marker for G1 entry during } \\
\text { cell cycle }\end{array}$ & IHC: $1: 250$ & Abcam & ab16663 (SP4) \\
\hline GAPDH & Mouse monoclonal & Loading control for WB & WB: $1: 10000$ & Abcam & $\mathrm{ab8245}(6 \mathrm{C} 5)$ \\
\hline GFAP & Rabbit polyclonal & Activated astrocytes & IHC: $1: 500$ & Abcam & ab7260 (N/A) \\
\hline MAG & Mouse monoclonal & $\begin{array}{l}\text { Myelin associated } \\
\text { glycoprotein }\end{array}$ & WB: $1: 1000$ & Millipore & MAB1567 (N/A) \\
\hline MAP2 & Chicken polyclonal & Neuronal/dendritic marker & IHC: $1: 2000$ & Abcam & ab5392 (N/A) \\
\hline MAP2 & Mouse monoclonal & Neuronal/dendritic marker & WB: $1: 5000$ & Abcam & $\begin{array}{l}\text { ab118853 } \\
\text { (MT-07) }\end{array}$ \\
\hline MBP & Mouse monoclonal & $\begin{array}{l}\text { Myelin basic protein; Myelin; } \\
\text { Myelinating OL }\end{array}$ & $\begin{array}{l}\text { IHC: } 1: 1000 \\
\text { ICC: } 1: 500 \\
\text { WB: } 1: 2000\end{array}$ & Covance & SMI-99P (N/A) \\
\hline MOG & Mouse monoclonal & $\begin{array}{l}\text { Myelin Oligodendrocyte } \\
\text { Glycoprotein }\end{array}$ & $\begin{array}{l}\text { WB } 1: 1000 \\
\text { ICC } 1: 500\end{array}$ & Millipore & MAB5680 (N/A) \\
\hline MyRF & Rabbit polyclonal & $\begin{array}{l}\text { Perinuclear region and } \\
\text { nucleus of postmitotic and } \\
\text { myelinating OL }\end{array}$ & IHC: $1: 250$ & $\begin{array}{l}\text { EMD } \\
\text { Millipore }\end{array}$ & ABN45 (N/A) \\
\hline $\mathrm{NeuN}$ & Mouse monoclonal & Pan-neuronal nuclei marker & WB $1: 1000$ & Millipore & MAB377 (A60) \\
\hline $\begin{array}{l}\text { NG2 } \\
\text { (CSPG4) }\end{array}$ & Rabbit polyclonal & Marker of OL progenitor cells & WB: $1: 500$ & $\begin{array}{l}\text { EMD } \\
\text { Millipore }\end{array}$ & AB5320 (N/A) \\
\hline Olig2 & Mouse monoclonal & $\begin{array}{l}\text { Pan-OL-specific nuclear } \\
\text { transcription factor }\end{array}$ & $\begin{array}{l}\text { IHC: } 1: 250 \\
\text { WB: } 1: 500\end{array}$ & $\begin{array}{l}\text { EMD } \\
\text { Millipore }\end{array}$ & $\begin{array}{l}\text { MABN50 } \\
(211 \mathrm{~F} 1.1) \\
\end{array}$ \\
\hline pATM & Rabbit polyclonal & $\begin{array}{l}\text { Ataxia telangiectasia mutated } \\
\text { DSB repair protein } \\
\text { phosphorylated at serine } 1981\end{array}$ & ICC: $1: 250$ & Abcam & $\begin{array}{l}\text { ab81292 } \\
(\mathrm{EP} 1890 \mathrm{Y})\end{array}$ \\
\hline$\gamma \mathrm{H} 2 \mathrm{~A} . \mathrm{X}$ & Rabbit polyclonal & $\begin{array}{l}\text { Marker of double strand } \\
\text { breaks (DSB) Phosphorylated } \\
\text { at serine } 139\end{array}$ & $\begin{array}{l}\text { IHC: } 1: 250 \\
\text { ICC: } 1: 250\end{array}$ & Abcam & ab2893 (N/A) \\
\hline PLP & Rabbit polyclonal & Myelin proteolipid protein & WB $1: 1000$ & Thermofisher & PA3-150 (N/A) \\
\hline $\mathrm{pS} / \mathrm{TQ}$ & Rabbit polyclonal & $\begin{array}{l}\text { Phospho-(Ser/Thr) } \\
\text { ATM/ATR Substrate }\end{array}$ & WB $1: 1000$ & Cell Signaling & $2851 \mathrm{~S}(\mathrm{~N} / \mathrm{A})$ \\
\hline $\mathrm{ROR} \alpha$ & Rabbit polyclonal & $\begin{array}{l}\text { Marker for purkinje cells in } \\
\text { cerebellum }\end{array}$ & WB $1: 1000$ & Abcam & ab60134 (N/A) \\
\hline Synapsin I & Rabbit polyclonal & Pre-synaptic marker & WB 1:1000 & Abcam & $\mathrm{ab64581} \mathrm{(N/A)}$ \\
\hline Tubulin $\beta$ III & Mouse monoclonal & $\begin{array}{l}\text { Neuron specific microtubule } \\
\text { in axon }\end{array}$ & WB $1: 1000$ & BioLegend & $\begin{array}{l}\text { MMS-435P } \\
\text { (N/A) }\end{array}$ \\
\hline
\end{tabular}

Table S2. List of primary antibodies in all immuno-based experiments 
medRxiv preprint doi: https://doi.org/10.1101/2021.01.22.20245217; this version posted January 26,2021 . The copyright holder for this preprint (which was not certified by peer review) is the author/funder, who has granted medRxiv a license to display the preprint in perpetuity.

All rights reserved. No reuse allowed without permission.

\section{References}

1. Swift, M., et al., The incidence and gene frequency of ataxia-telangiectasia in the United States. Am J Hum Genet, 1986. 39(5): p. 573-83.

2. $\quad$ Salman, M.S., et al., The epidemiology of intermittent and chronic ataxia in children in Manitoba, Canada. Dev Med Child Neurol, 2013. 55(4): p. 341-7.

3. Taylor, A.M., et al., Ataxia telangiectasia: more variation at clinical and cellular levels. Clin Genet, 2015. 87(3): p. 199-208.

4. $\quad$ Savitsky, K., et al., A single ataxia telangiectasia gene with a product similar to PI-3 kinase. Science, 1995. 268(5218): p. 1749-53.

5. $\quad$ Paull, T.T., Mechanisms of ATM Activation. Annu Rev Biochem, 2015. 84: p. 711-38.

6. Boehrs, J.K., et al., Constitutive expression and cytoplasmic compartmentalization of ATM protein in differentiated human neuron-like SH-SY5Y cells. J Neurochem, 2007. 100(2): p. $337-45$.

7. $\quad \mathrm{Li}$, J., et al., Nuclear accumulation of HDAC4 in ATM deficiency promotes neurodegeneration in ataxia telangiectasia. Nat Med, 2012. 18(5): p. 783-90.

8. Barlow, C., et al., ATM is a cytoplasmic protein in mouse brain required to prevent lysosomal accumulation. Proc Natl Acad Sci U S A, 2000. 97(2): p. 871-6.

9. Watters, D., et al., Localization of a portion of extranuclear ATM to peroxisomes. J Biol Chem, 1999. 274(48): p. 34277-82.

10. Lim, D.S., et al., ATM binds to beta-adaptin in cytoplasmic vesicles. Proc Natl Acad Sci U S A, 1998. 95(17): p. 10146-51.

11. Li, J., et al., Cytoplasmic ATM in neurons modulates synaptic function. Curr Biol, 2009. 19(24): p. 2091-6.

12. Valentin-Vega, Y.A., et al., Mitochondrial dysfunction in ataxia-telangiectasia. Blood, 2012. 119(6): p. 1490-500.

13. Maryanovich, M., et al., The ATM-BID pathway regulates quiescence and survival of haematopoietic stem cells. Nat Cell Biol, 2012. 14(5): p. 535-41.

14. Lee, J.H., et al., ATM directs DNA damage responses and proteostasis via genetically separable pathways. Sci Signal, 2018. 11(512).

15. Chen, P., et al., Oxidative stress is responsible for deficient survival and dendritogenesis in purkinje neurons from ataxia-telangiectasia mutated mutant mice. J Neurosci, 2003. 23(36): p. 11453-60.

16. Ditch, S. and T.T. Paull, The ATM protein kinase and cellular redox signaling: beyond the DNA damage response. Trends Biochem Sci, 2012. 37(1): p. 15-22.

17. Guo, Z., et al., ATM activation by oxidative stress. Science, 2010. 330(6003): p. 517-21.

18. Kamsler, A., et al., Increased oxidative stress in ataxia telangiectasia evidenced by alterations in redox state of brains from Atm-deficient mice. Cancer Res, 2001. 61(5): p. 1849-54.

19. Kozlov, S.V., et al., Reactive Oxygen Species (ROS)-Activated ATM-Dependent Phosphorylation of Cytoplasmic Substrates Identified by Large-Scale Phosphoproteomics Screen. Mol Cell Proteomics, 2016. 15(3): p. 1032-47.

20. Chow, H.M., et al., ATM is activated by ATP depletion and modulates mitochondrial function through NRF1. J Cell Biol, 2019.

21. Hinz, M., et al., A cytoplasmic ATM-TRAF6-cIAP1 module links nuclear DNA damage signaling to ubiquitin-mediated NF-kappaB activation. Mol Cell, 2010. 40(1): p. 63-74.

22. Wu, Z.H., et al., Molecular linkage between the kinase ATM and NF-kappaB signaling in response to genotoxic stimuli. Science, 2006. 311(5764): p. 1141-6.

23. Wu, Z.H., et al., ATM- and NEMO-dependent ELKS ubiquitination coordinates TAK1mediated IKK activation in response to genotoxic stress. Mol Cell, 2010. 40(1): p. 75-86.

24. Fang, L., et al., ATM regulates NF-kappaB-dependent immediate-early genes via RelA Ser 276 phosphorylation coupled to CDK9 promoter recruitment. Nucleic Acids Res, 2014. 42(13): p. 8416-32. 
medRxiv preprint doi: https://doi.org/10.1101/2021.01.22.20245217; this version posted January 26, 2021. The copyright holder for this

preprint (which was not certified by peer review) is the author/funder, who has granted medRxiv a license to display the preprint in perpetuity.

Tse et al

25. Cheng, A., et al., ATM and ATR play complementary roles in the behavior of excitatory and inhibitory vesicle populations. Proc Natl Acad Sci U S A, 2018. 115(2): p. E292-E301.

26. Sahama, I., et al., Motor pathway degeneration in young ataxia telangiectasia patients: A diffusion tractography study. Neuroimage Clin, 2015. 9: p. 206-15.

27. De Leon, G.A., W.D. Grover, and D.S. Huff, Neuropathologic changes in ataxiatelangiectasia. Neurology, 1976. 26(10): p. 947-51.

28. Strich, S.J., Pathological findings in three cases of ataxia-telangiectasia. J Neurol Neurosurg Psychiatry. , 1966. 29(6): p. 489-499.

29. Terplan, K.L. and R.F. Krauss, Histopathologic brain changes in association with ataxiatelangiectasia. Neurology, 1969. 19(5): p. 446-54.

30. Aguilar, M.J., et al., Pathological observations in ataxia-telangiectasia. A report of five cases. J Neuropathol Exp Neurol, 1968. 27(4): p. 659-76.

31. Sourander, P., J.O. Bonnevier, and Y. Olsson, A case of ataxia-telangiectasia with lesions in the spinal cord. Acta Neurol Scand, 1966. 42(3): p. 354-66.

32. Serizawa, M., et al., [Histological and radiobiological study on adult cases with ataxia telangiectasia]. Rinsho Shinkeigaku, 1994. 34(1): p. 38-42.

33. Chung, E.O., et al., Cerebral white-matter changes suggesting leukodystrophy in ataxia telangiectasia. J Child Neurol, 1994. 9(1): p. 31-5.

34. Gouw, A.A., et al., Heterogeneity of white matter hyperintensities in Alzheimer's disease: post-mortem quantitative MRI and neuropathology. Brain, 2008. 131(Pt 12): p. 3286-98.

35. McAleese, K.E., et al., Parietal white matter lesions in Alzheimer's disease are associated with cortical neurodegenerative pathology, but not with small vessel disease. Acta Neuropathol, 2017.

36. Sahama, I., et al., Radiological imaging in ataxia telangiectasia: a review. Cerebellum, 2014. 13(4): p. 521-30.

37. Enriquez-Rios, V., et al., DNA-PKcs, ATM, and ATR Interplay Maintains Genome Integrity during Neurogenesis. J Neurosci, 2017. 37(4): p. 893-905.

38. Allen, D.M., et al., Ataxia telangiectasia mutated is essential during adult neurogenesis. Genes Dev, 2001. 15(5): p. 554-66.

39. Carlessi, L., et al., DNA-damage response, survival and differentiation in vitro of a human neural stem cell line in relation to ATM expression. Cell Death Differ, 2009. 16(6): p. 795806.

40. Carlessi, L., et al., ATM-deficient human neural stem cells as an in vitro model system to study neurodegeneration. DNA Repair (Amst), 2013. 12(8): p. 605-11.

41. Bell, C.J., et al., Carrier testing for severe childhood recessive diseases by next-generation sequencing. Sci Transl Med, 2011. 3(65): p. 65ra4.

42. $\mathrm{Xu}, \mathrm{Y}$., et al., Targeted disruption of ATM leads to growth retardation, chromosomal fragmentation during meiosis, immune defects, and thymic lymphoma. Genes Dev, 1996. 10(19): p. 2411-22.

43. Lavin, M.F., The appropriateness of the mouse model for ataxia-telangiectasia: neurological defects but no neurodegeneration. DNA Repair (Amst), 2013. 12(8): p. 612-9.

44. Emery, B. and J.C. Dugas, Purification of oligodendrocyte lineage cells from mouse cortices by immunopanning. Cold Spring Harb Protoc, 2013. 2013(9): p. 854-68.

45. Luo, F., et al., The Activators of Cyclin-Dependent Kinase 5 p35 and p39 Are Essential for Oligodendrocyte Maturation, Process Formation, and Myelination. J Neurosci, 2016. 36(10): p. 3024-37.

46. Tse, K.H., et al., DNA damage-associated oligodendrocyte degeneration precedes amyloid pathology and contributes to Alzheimer's disease and dementia. Alzheimers Dement, 2018.

47. Sohl, G., et al., The oligodendroglial precursor cell line Oli-neu represents a cell culture system to examine functional expression of the mouse gap junction gene connexin29 (Cx29). Front Pharmacol, 2013. 4: p. 83.

48. Jung, M., et al., Lines of murine oligodendroglial precursor cells immortalized by an activated neu tyrosine kinase show distinct degrees of interaction with axons in vitro and in vivo. Eur J Neurosci, 1995. 7(6): p. 1245-65. 
medRxiv preprint doi: https://doi.org/10.1101/2021.01.22.20245217; this version posted January 26, 2021. The copyright holder for this preprint (which was not certified by peer review) is the author/funder, who has granted medRxiv a license to display the preprint in perpetuity.

Tse et al medRxiv

49. Pereira, G.B., et al., Expression of myelin genes: comparative analysis of Oli-neu and N20.1 oligodendroglial cell lines. J Neurosci Res, 2011. 89(7): p. 1070-8.

50. Cicero, S. and K. Herrup, Cyclin-dependent kinase 5 is essential for neuronal cell cycle arrest and differentiation. J Neurosci, 2005. 25(42): p. 9658-68.

51. Cui, Y., et al., Activation of the Rab7 GTPase by the MON1-CCZ1 Complex Is Essential for PVC-to-Vacuole Trafficking and Plant Growth in Arabidopsis. Plant Cell, 2014. 26(5): p. 2080-2097.

52. Spandidos, A., et al., PrimerBank: a resource of human and mouse PCR primer pairs for gene expression detection and quantification. Nucleic Acids Res, 2010. 38(Database issue): p. D792-9.

53. Livak, K.J. and T.D. Schmittgen, Analysis of relative gene expression data using real-time quantitative PCR and the 2(-Delta Delta C(T)) Method. Methods, 2001. 25(4): p. 402-8.

54. Kelley, L.A., et al., The Phyre 2 web portal for protein modeling, prediction and analysis. Nat Protoc, 2015. 10(6): p. 845-58.

55. Kozakov, D., et al., The ClusPro web server for protein-protein docking. Nat Protoc, 2017. 12(2): p. 255-278.

56. Chow, H.M. and K. Herrup, Genomic integrity and the ageing brain. Nat Rev Neurosci, 2015. 16(11): p. 672-84.

57. Tse, K.H. and K. Herrup, DNA damage in the oligodendrocyte lineage and its role in brain aging. Mech Ageing Dev, 2017. 161(Pt A): p. 37-50.

58. Tse, K.H., et al., DNA damage-associated oligodendrocyte degeneration precedes amyloid pathology and contributes to Alzheimer's disease and dementia. Alzheimers Dement, 2018. 14(5): p. 664-679.

59. Li, J., et al., Stable brain ATM message and residual kinase-active ATM protein in ataxiatelangiectasia. J Neurosci, 2011. 31(20): p. 7568-77.

60. Bin, J.M., S.N. Harris, and T.E. Kennedy, The oligodendrocyte-specific antibody 'CCl' binds Quaking 7. J Neurochem, 2016. 139(2): p. 181-186.

61. Zhu, X., et al., Olig2-dependent developmental fate switch of NG2 cells. Development, 2012. 139(13): p. 2299-307.

62. Zuo, H., et al., Age-dependent decline in fate switch from NG2 cells to astrocytes after Olig2 deletion. J Neurosci, 2018.

63. Zhao, J.W., et al., Astrocytes and oligodendrocytes can be generated from NG2+ progenitors after acute brain injury: intracellular localization of oligodendrocyte transcription factor 2 is associated with their fate choice. Eur J Neurosci, 2009. 29(9): p. 1853-69.

64. Cassiani-Ingoni, R., et al., Cytoplasmic translocation of Olig2 in adult glial progenitors marks the generation of reactive astrocytes following autoimmune inflammation. Exp Neurol, 2006. 201(2): p. 349-58.

65. Sandoval, N., et al., Characterization of ATM gene mutations in 66 ataxia telangiectasia families. Hum Mol Genet, 1999. 8(1): p. 69-79.

66. $\mathrm{Li}, \mathrm{A}$. and M. Swift, Mutations at the ataxia-telangiectasia locus and clinical phenotypes of A-T patients. Am J Med Genet, 2000. 92(3): p. 170-7.

67. Woodbine, L., et al., Endogenously induced DNA double strand breaks arise in heterochromatic DNA regions and require ataxia telangiectasia mutated and Artemis for their repair. Nucleic Acids Res, 2011. 39(16): p. 6986-97.

68. Back, S.A., et al., Selective vulnerability of late oligodendrocyte progenitors to hypoxiaischemia. J Neurosci, 2002. 22(2): p. 455-63.

69. Biname, F., et al., NG2 regulates directional migration of oligodendrocyte precursor cells via Rho GTPases and polarity complex proteins. J Neurosci, 2013. 33(26): p. 10858-74.

70. Golding, S.E., et al., Improved ATM kinase inhibitor KU-60019 radiosensitizes glioma cells, compromises insulin, AKT and ERK prosurvival signaling, and inhibits migration and invasion. Mol Cancer Ther, 2009. 8(10): p. 2894-902.

71. Kuljis, R.O., et al., Degeneration of neurons, synapses, and neuropil and glial activation in a murine Atm knockout model of ataxia-telangiectasia. Proc Natl Acad Sci U S A, 1997.

94(23): p. 12688-93. 
medRxiv preprint doi: https://doi.org/10.1101/2021.01.22.20245217; this version posted January 26, 2021. The copyright holder for this

preprint (which was not certified by peer review) is the author/funder, who has granted medRxiv a license to display the preprint in perpetuity.

Tse et al

medRxiv

72. Yang, Y. and K. Herrup, Loss of neuronal cell cycle control in ataxia-telangiectasia: a unified disease mechanism. J Neurosci, 2005. 25(10): p. 2522-9.

73. Herrup, K., Post-mitotic role of the cell cycle machinery. Curr Opin Cell Biol, 2013. 25(6): p. 711-6.

74. Cara, L., et al., The ATM- and ATR-related SCD domain is over-represented in proteins involved in nervous system development. Sci Rep, 2016. 6: p. 19050.

75. Baretic, D., et al., Structures of closed and open conformations of dimeric human ATM. Sci Adv, 2017. 3(5): p. e1700933.

76. Schulz, P., T.F. Cruz, and M.A. Moscarello, Endogenous phosphorylation of basic protein in myelin of varying degrees of compaction. Biochemistry, 1988. 27(20): p. 7793-9.

77. Bujalka, H., et al., MYRF is a membrane-associated transcription factor that autoproteolytically cleaves to directly activate myelin genes. PLoS Biol, 2013. 11(8): p. e1001625.

78. Sahama, I., et al., Altered corticomotor-cerebellar integrity in young ataxia telangiectasia patients. Mov Disord, 2014. 29(10): p. 1289-98.

79. Erten-Lyons, D., et al., Neuropathologic basis of white matter hyperintensity accumulation with advanced age. Neurology, 2013. 81(11): p. 977-83.

80. Dineen, R.A., et al., Multiparametric cerebellar imaging and clinical phenotype in childhood ataxia telangiectasia. Neuroimage Clin, 2020. 25: p. 102110.

81. Hui, C.W. and K. Herrup, Individual Cytokines Modulate the Neurological Symptoms of ATM Deficiency in a Region Specific Manner. eNeuro, 2015. 2(4).

82. Jiang, D., et al., Alteration in 5-hydroxymethylcytosine-mediated epigenetic regulation leads to Purkinje cell vulnerability in ATM deficiency. Brain, 2015. 138(Pt 12): p. 3520-36.

83. Psachoulia, K., et al., Cell cycle dynamics of NG2 cells in the postnatal and ageing brain. Neuron Glia Biol, 2009. 5(3-4): p. 57-67.

84. Young, K.M., et al., Oligodendrocyte dynamics in the healthy adult CNS: evidence for myelin remodeling. Neuron, 2013. 77(5): p. 873-85.

85. Liu, B., et al., DNA damage and oxidative injury are associated with hypomyelination in the corpus callosum of newborn Nbn(CNS-del) mice. J Neurosci Res, 2014. 92(2): p. 254-66.

86. Mehta, A. and J.E. Haber, Sources of DNA double-strand breaks and models of recombinational DNA repair. Cold Spring Harb Perspect Biol, 2014. 6(9): p. a016428.

87. Lee, Y., et al., Defective neurogenesis resulting from DNA ligase IV deficiency requires Atm. Genes Dev, 2000. 14(20): p. 2576-80.

88. Emery, B., et al., Myelin gene regulatory factor is a critical transcriptional regulator required for CNS myelination. Cell, 2009. 138(1): p. 172-85.

89. Zhang, Y., et al., An RNA-sequencing transcriptome and splicing database of glia, neurons, and vascular cells of the cerebral cortex. J Neurosci, 2014. 34(36): p. 11929-47.

90. Li, J., et al., EZH2-mediated H3K27 trimethylation mediates neurodegeneration in ataxiatelangiectasia. Nat Neurosci, 2013. 16(12): p. 1745-53.

91. Yang, Y., et al., The interaction of the atm genotype with inflammation and oxidative stress. PLoS One, 2014. 9(1): p. e85863.

92. Shen, X., et al., Neurons in vulnerable regions of the Alzheimer's disease brain display reduced ATM signaling. eNeuro, 2016. 3(1).

93. Herrup, K. and Y. Yang, Cell cycle regulation in the postmitotic neuron: oxymoron or new biology? Nat Rev Neurosci, 2007. 8(5): p. 368-78.

94. Vail, G., et al., ATM protein is located on presynaptic vesicles and its deficit leads to failures in synaptic plasticity. J Neurophysiol, 2016. 116(1): p. 201-9.

95. Zhang, Y., et al., Mitochondrial redox sensing by the kinase ATM maintains cellular antioxidant capacity. Sci Signal, 2018. 11(538).

96. Bergles, D.E. and W.D. Richardson, Oligodendrocyte Development and Plasticity. Cold Spring Harb Perspect Biol, 2015. 8(2): p. a020453.

97. $\mathrm{Yu}, \mathrm{Y}$., et al., Olig2 targets chromatin remodelers to enhancers to initiate oligodendrocyte differentiation. Cell, 2013. 152(1-2): p. 248-61.

98. Van de Kaa, C.A., et al., Postmortem findings in the Nijmegen breakage syndrome. Pediatr Pathol, 1994. 14(5): p. 787-96. 
medRxiv preprint doi: https://doi.org/10.1101/2021.01.22.20245217; this version posted January $26,2021$. The copyright holder for this preprint (which was not certified by peer review) is the author/funder, who has granted medRxiv a license to display the preprint in All rights reserved. No reuse allowed without permission.

Tse et al

medRxiv

99. Verhagen, M.M., et al., Neuropathology in classical and variant ataxia-telangiectasia.

Neuropathology, 2012. 32(3): p. 234-44.

100. Shiloh, Y., ATM: expanding roles as a chief guardian of genome stability. Exp Cell Res, 2014. 329(1): p. 154-61.

101. Maraschio, P., et al., A novel mutation and novel features in Nijmegen breakage syndrome. $\mathrm{J}$ Med Genet, 2001. 38(2): p. 113-7.

102. Oba, D., et al., Autopsy study of cerebellar degeneration in siblings with ataxiatelangiectasia-like disorder. Acta Neuropathol, 2010. 119(4): p. 513-20.

103. Palmeri, S., et al., Clinical course of two Italian siblings with ataxia-telangiectasia-like disorder. Cerebellum, 2013. 12(4): p. 596-9.

104. Compe, E. and J.M. Egly, TFIIH: when transcription met DNA repair. Nat Rev Mol Cell Biol, 2012. 13(6): p. 343-54.

105. Compe, E., et al., Neurological defects in trichothiodystrophy reveal a coactivator function of TFIIH. Nat Neurosci, 2007. 10(11): p. 1414-22. 
medRxiv preprint doi: https://doi.org/10.1101/2021.01.22.20245217; this version posted January 26, 2021. The copyright holder for this preprint (which was not certified by peer review) is the author/funder, who has granted medRxiv a license to display the preprint in perpetuity.

All rights reserved. No reuse allowed without permission.

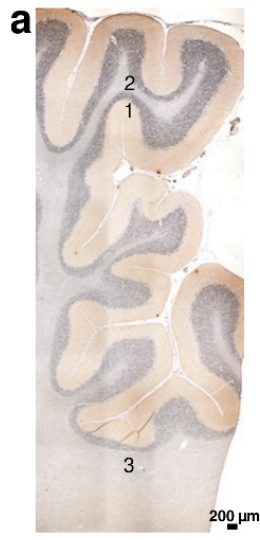

1 Purkinje layer

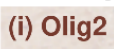

ing

b Normal aging

cerebellum

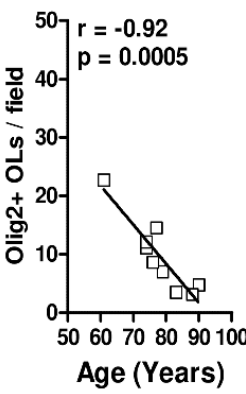

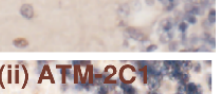
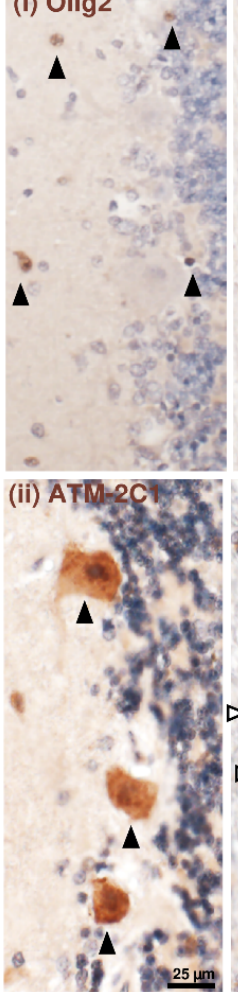

2 Folia WM

3 Deep WM
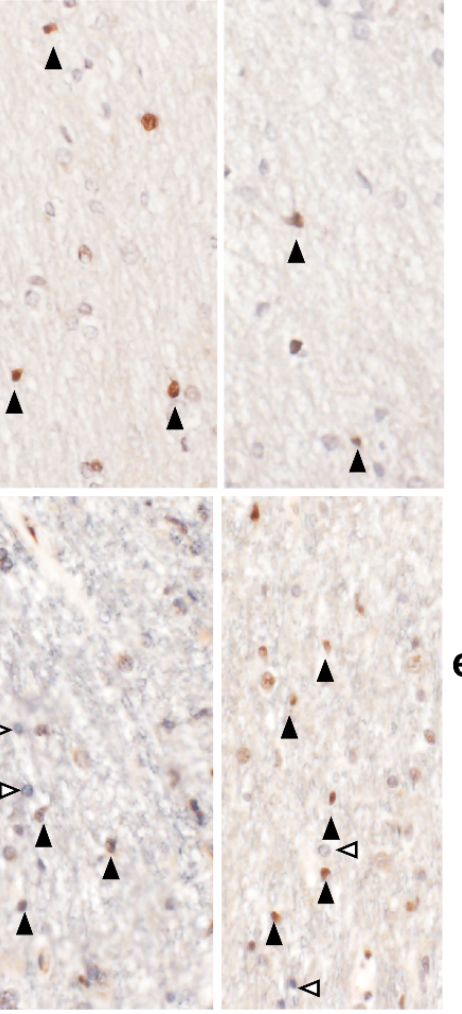

i

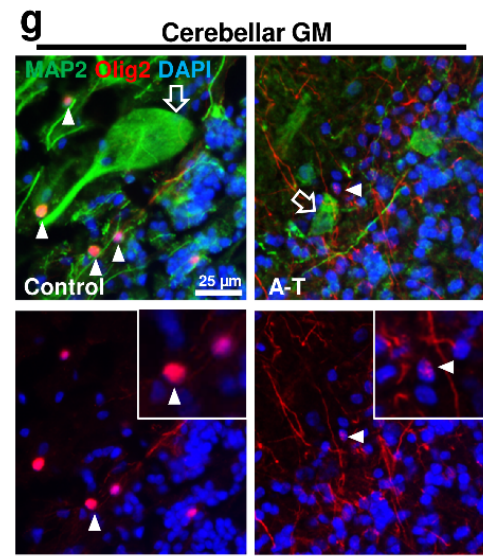

h

Cerebellar GM
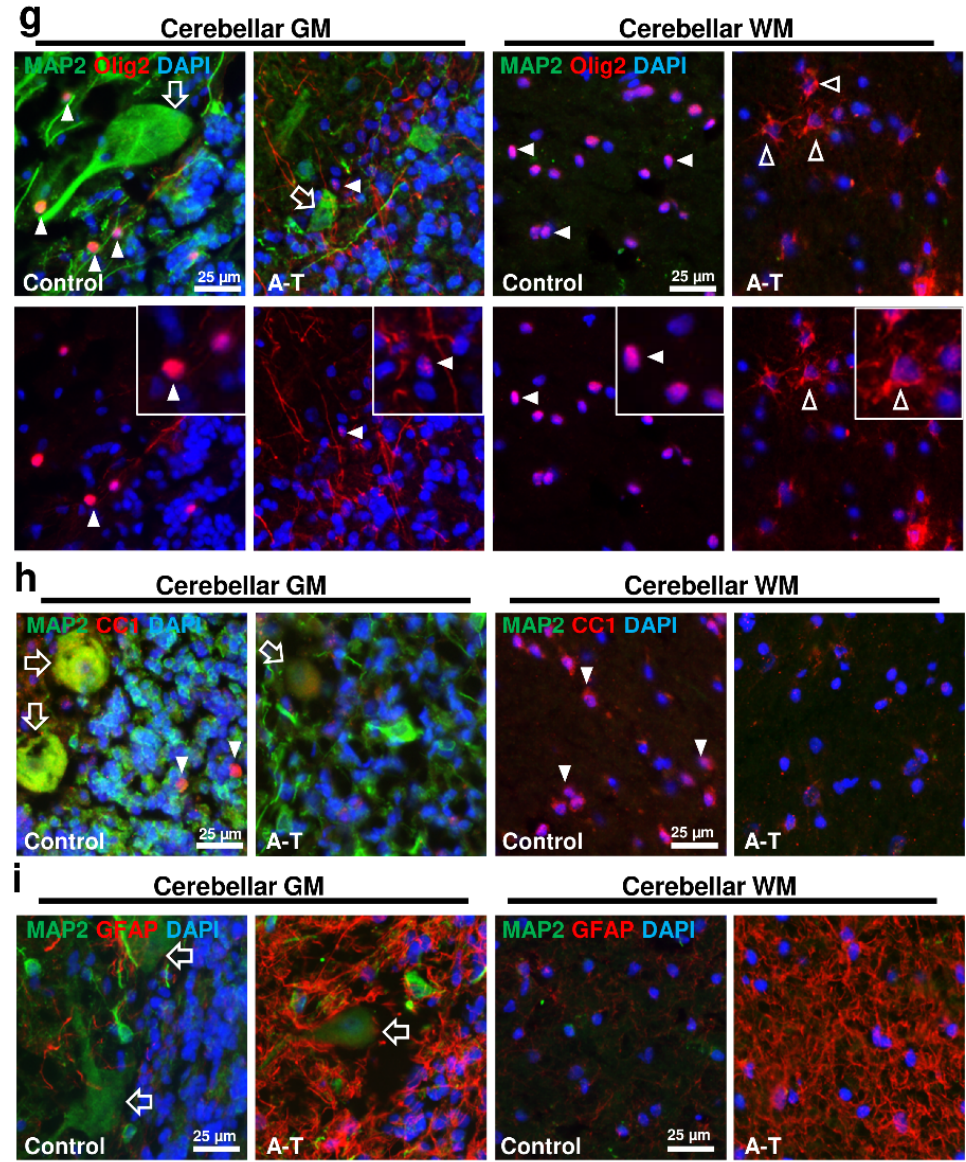

Cerebellar WM
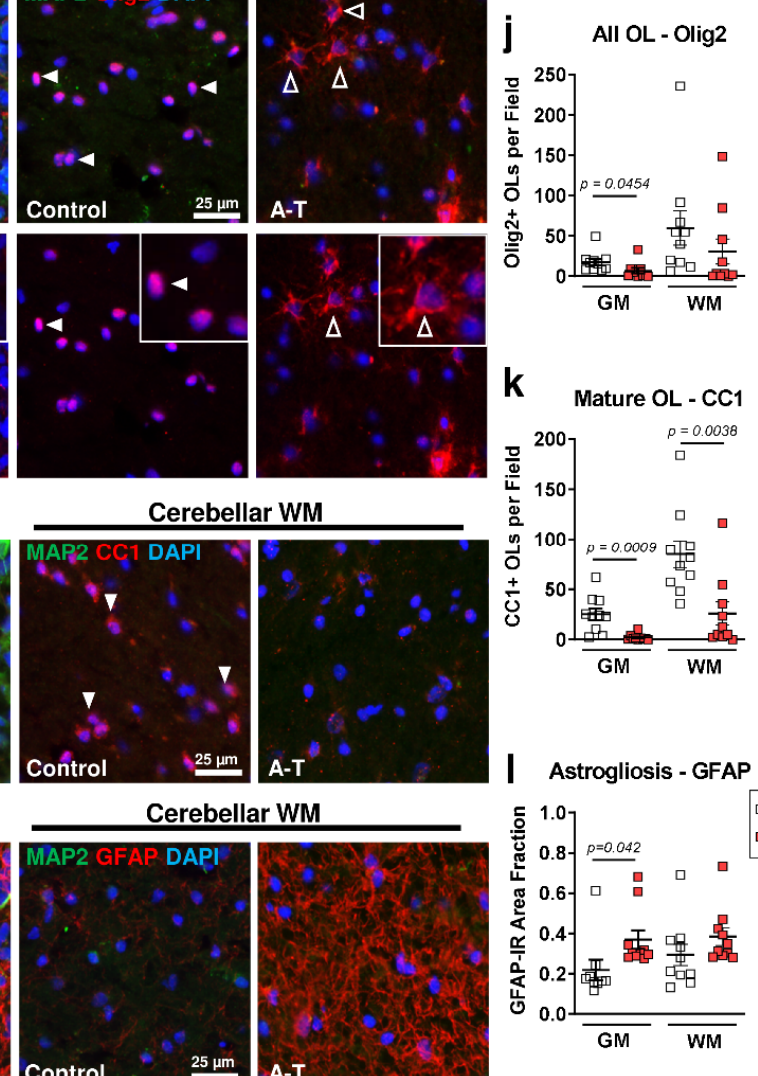
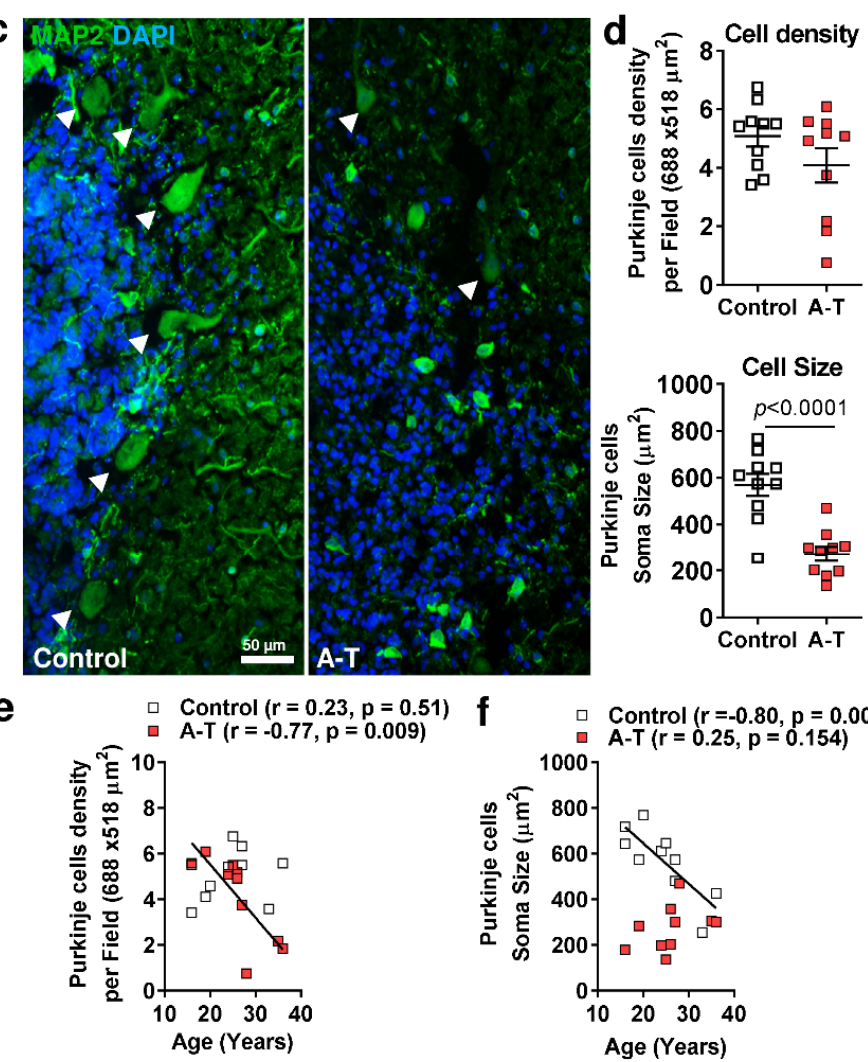

Figure 1. Loss of cerebellar neurons and OLs in Ataxia Telangiectasia 
medRxiv preprint doi: https://doi.org/10.1101/2021.01.22.20245217; this version posted January 26, 2021. The copyright holder for this preprint (which was not certified by peer review) is the author/funder, who has granted medRxiv a license to display the preprint in perpetuity.

All rights reserved. No reuse allowed without permission.

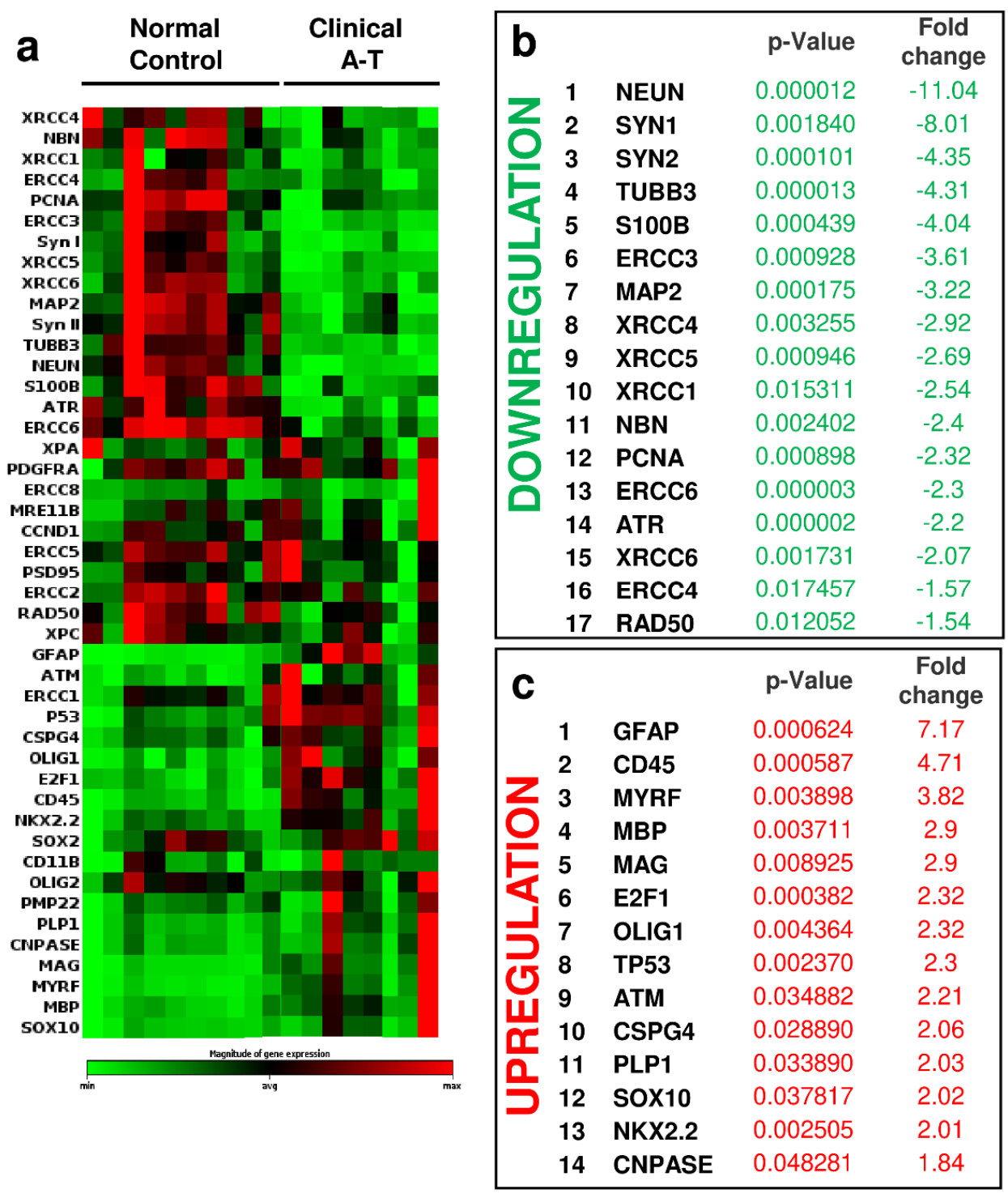

Figure 2. Gene expression profile in A-T cerebellum 
medRxiv preprint doi: https://doi.org/10.1101/2021.01.22.20245217; this version posted January 26, 2021. The copyright holder for this preprint (which was not certified by peer review) is the author/funder, who has granted medRxiv a license to display the preprint in perpetuity.

All rights reserved. No reuse allowed without permission.

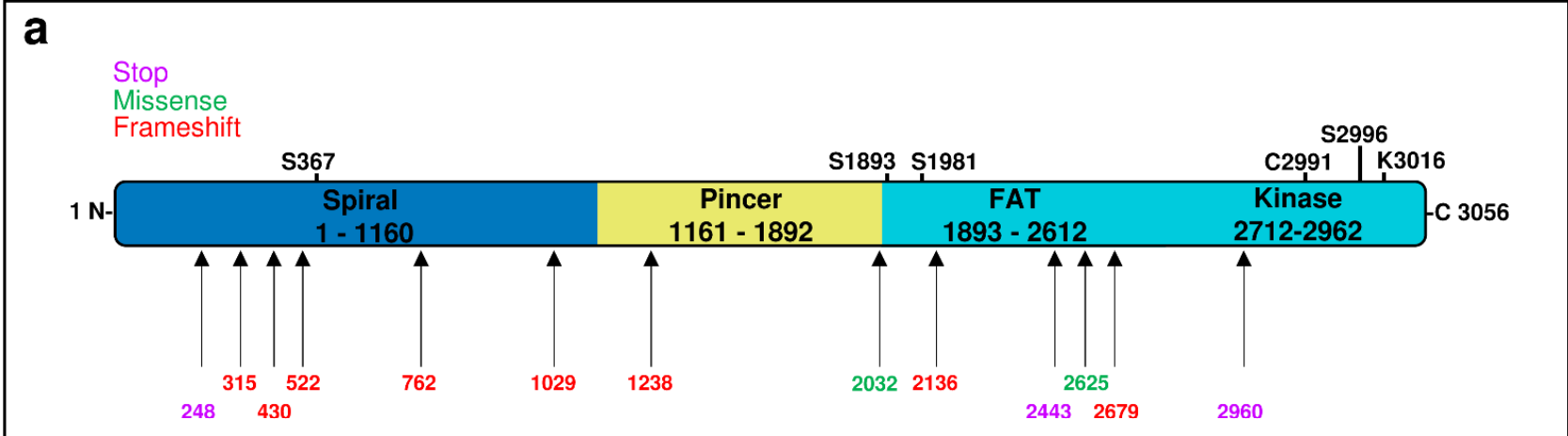

b
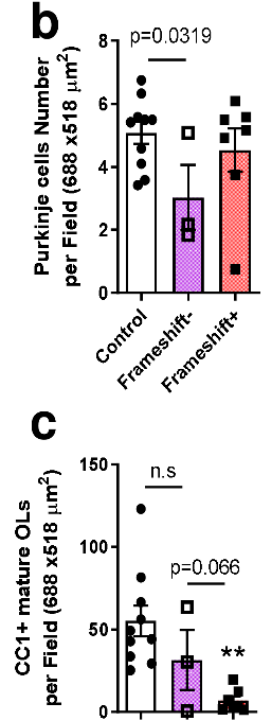
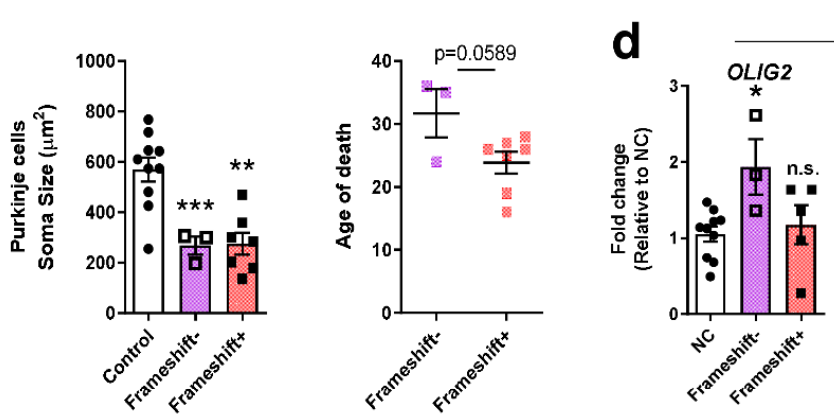

Oligodendrocyte-specific
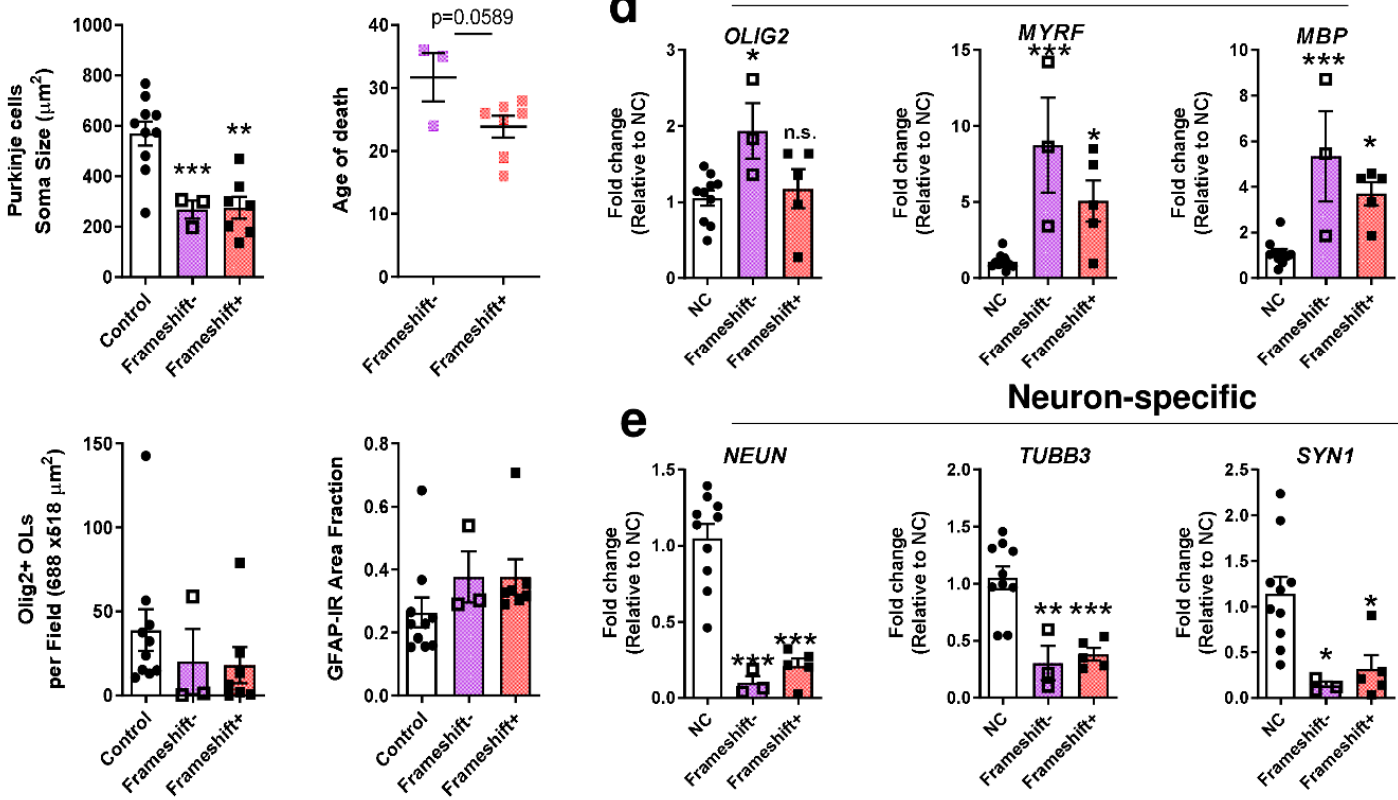

Astrocyte-specific

Figure 3. ATM mutation variants and neuropathology in A-T
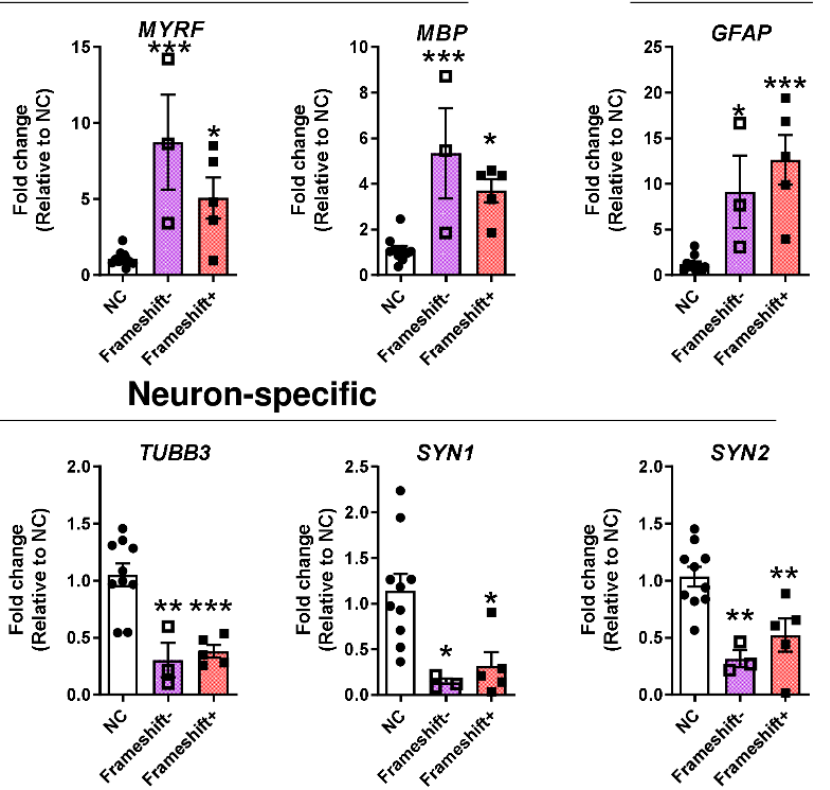

Neuron-specific 
medRxiv preprint doi: https://doi.org/10.1101/2021.01.22.20245217; this version posted January 26, 2021. The copyright holder for this preprint (which was not certified by peer review) is the author/funder, who has granted medRxiv a license to display the preprint in perpetuity.

All rights reserved. No reuse allowed without permission.

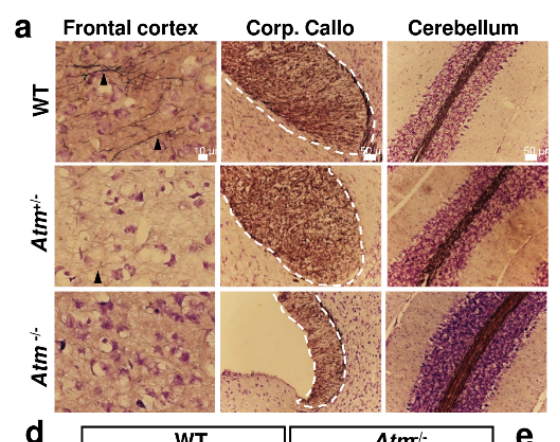

d

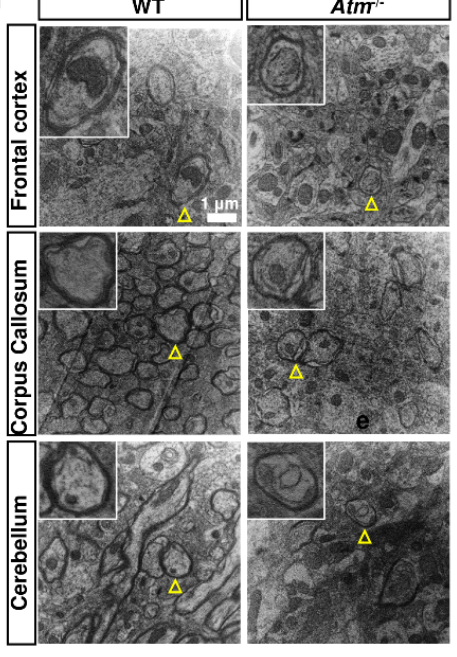

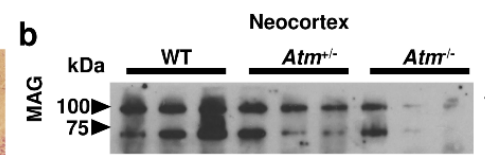

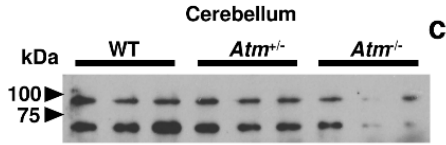

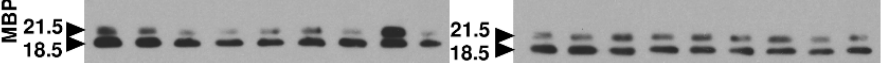

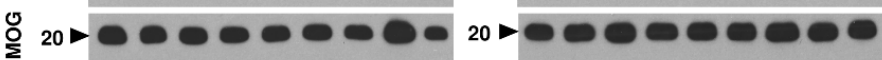

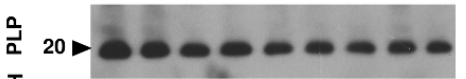

I
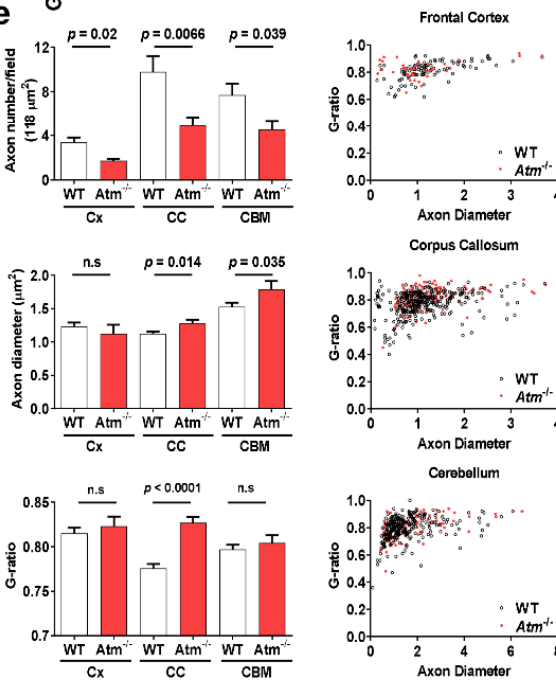

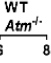

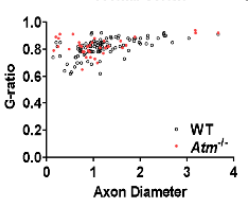

$\cos 60$

$f$
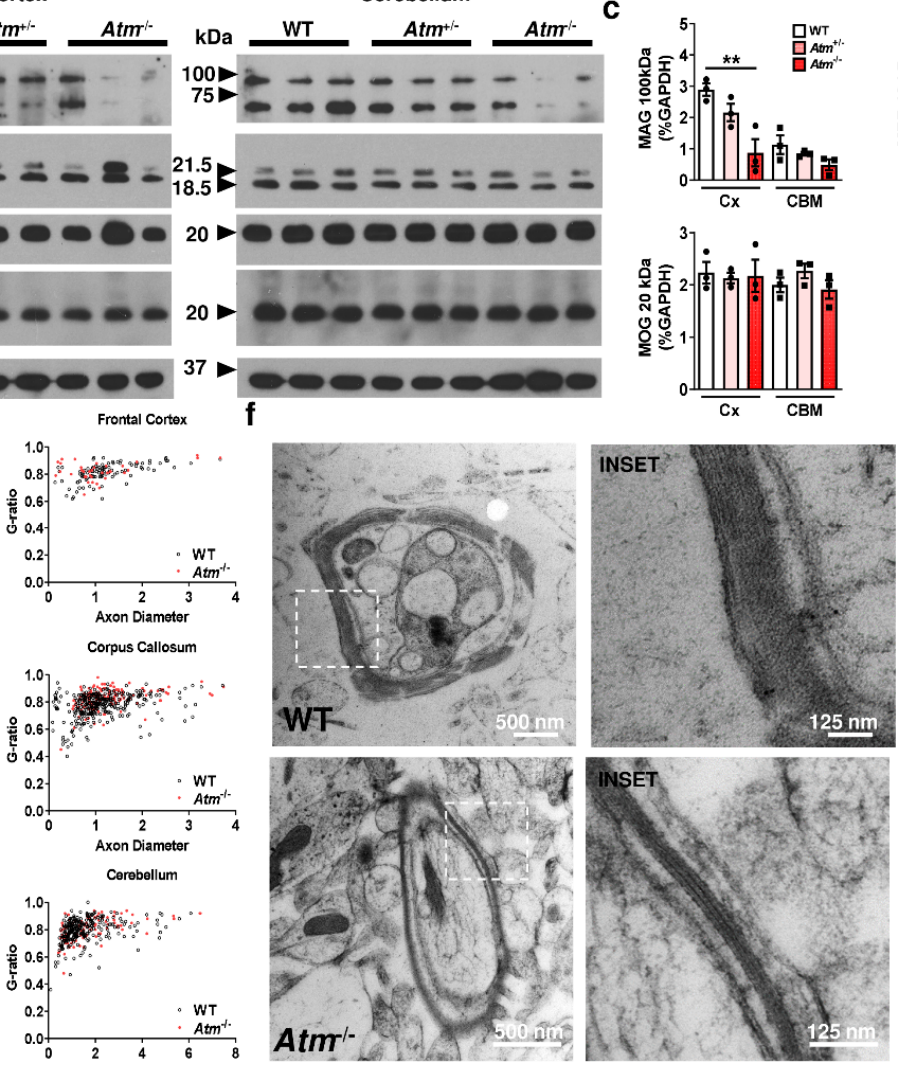
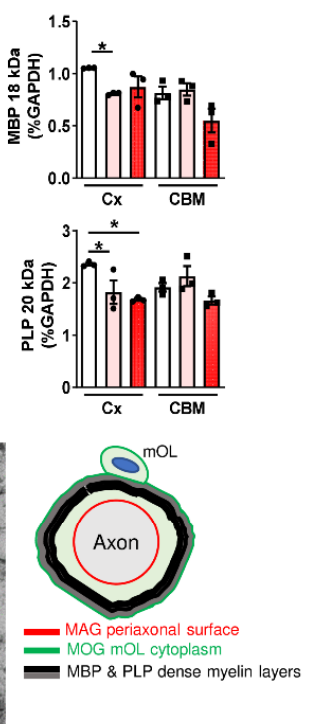

Figure 4. Myelin abnormalities in Atm-knockout mouse model $\left(\mathrm{Atm}^{-/}\right)$ 
medRxiv preprint doi: https://doi.org/10.1101/2021.01.22.20245217; this version posted January 26, 2021. The copyright holder for this preprint (which was not certified by peer review) is the author/funder, who has granted medRxiv a license to display the preprint in perpetuity. All rights reserved. No reuse allowed without permission.

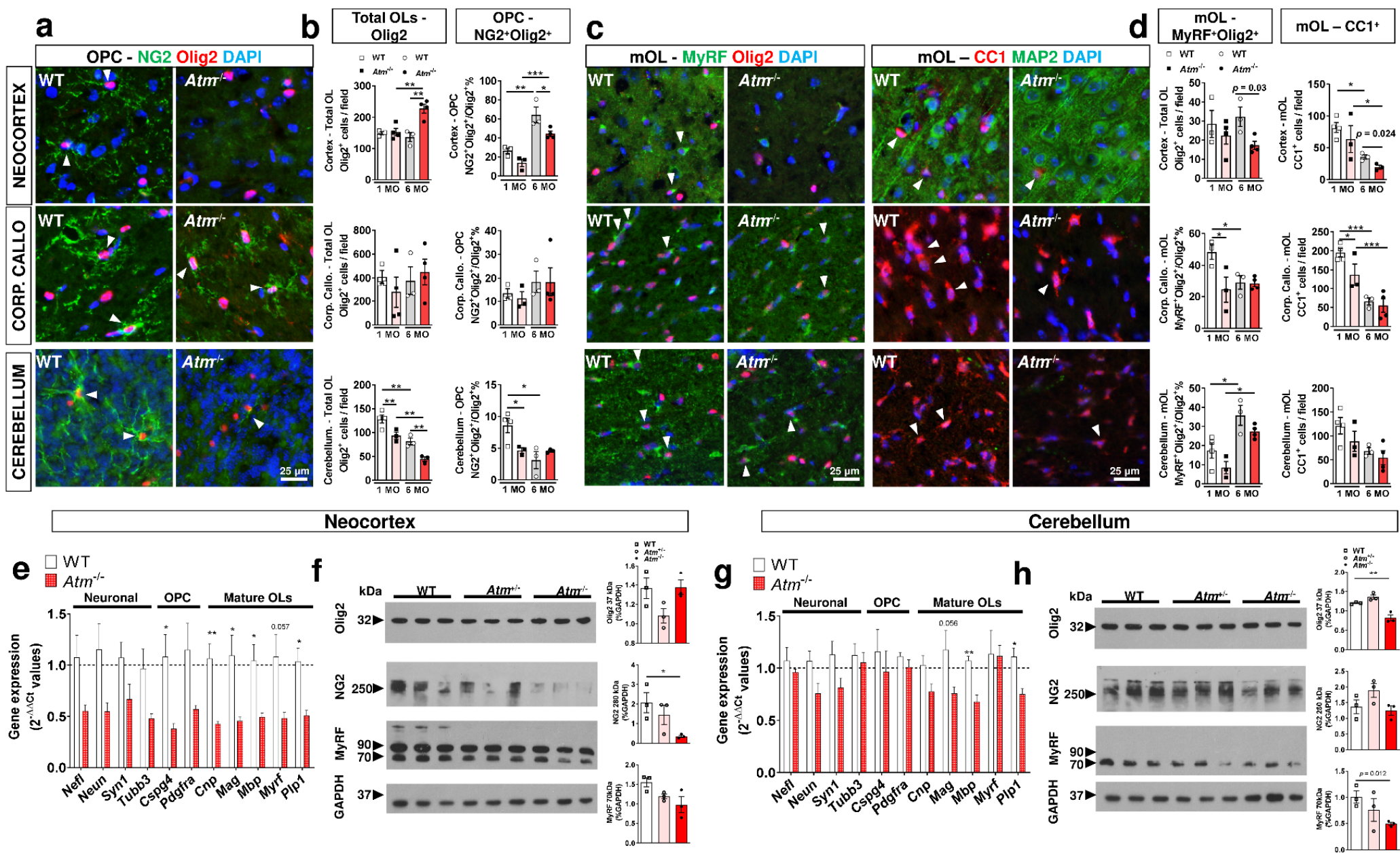

Figure 5. Age- and genotype-associated reduction of OLs in distinct brain regions of $\mathrm{Atm}^{-/}$mice 
medRxiv preprint doi: https://doi.org/10.1101/2021.01.22.20245217; this version posted January 26, 2021. The copyright holder for this preprint (which was not certified by peer review) is the author/funder, who has granted medRxiv a license to display the preprint in perpetuity.

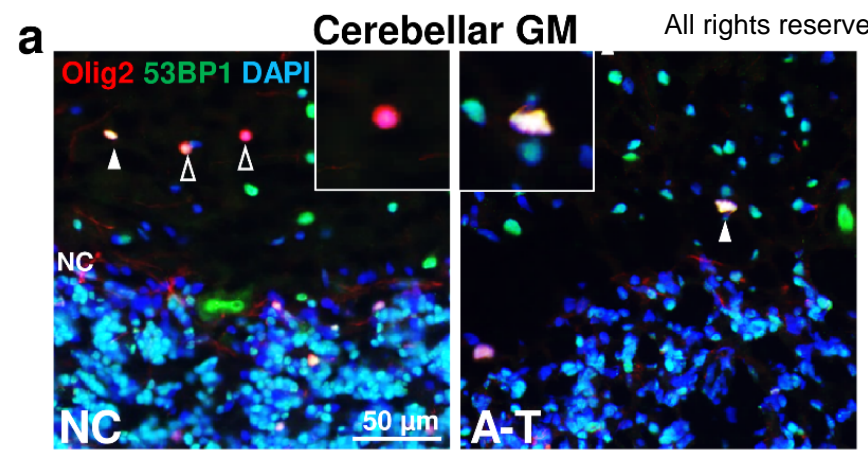
reuse allow

C

×

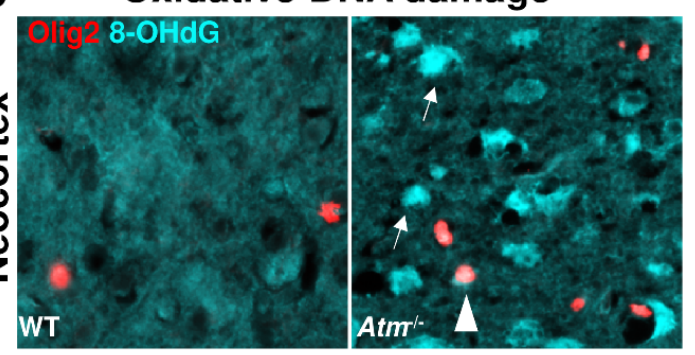

엉
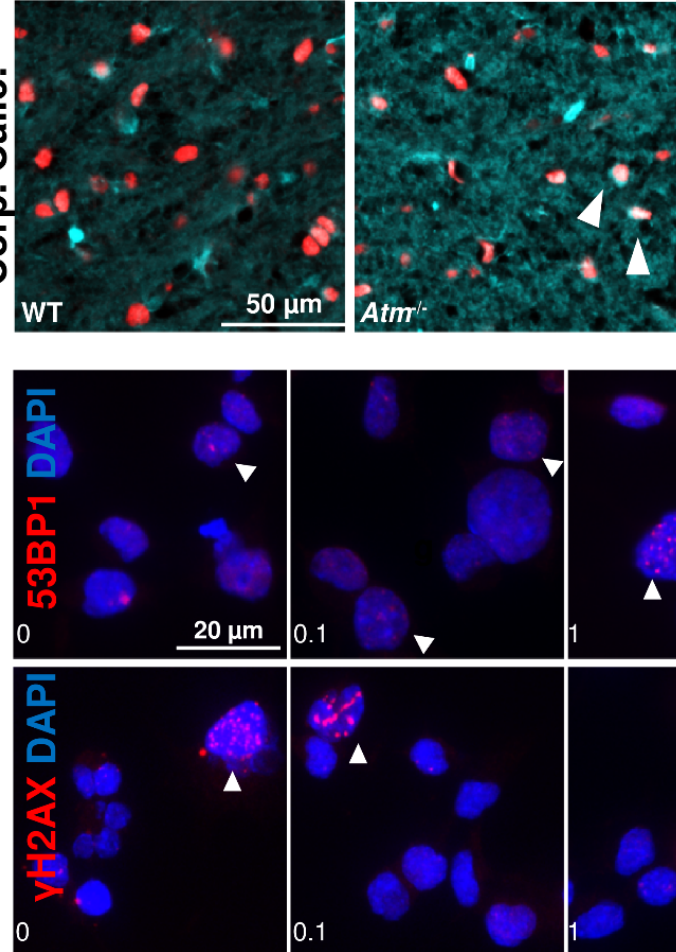

KU-60019 ATM inhibition (Conc. $\mu \mathrm{M}$ )

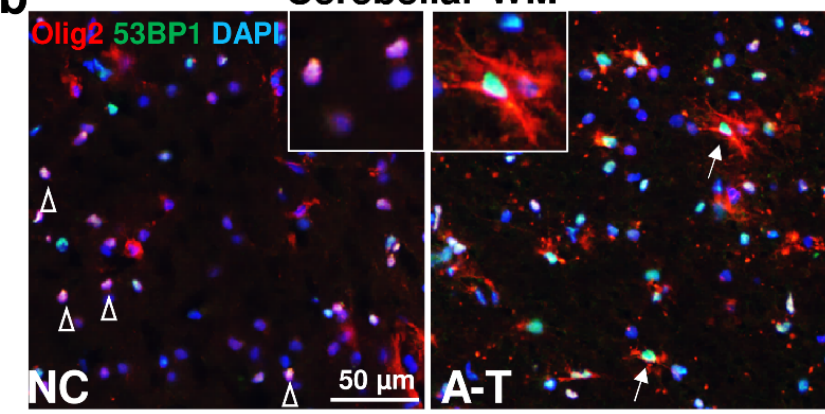

d
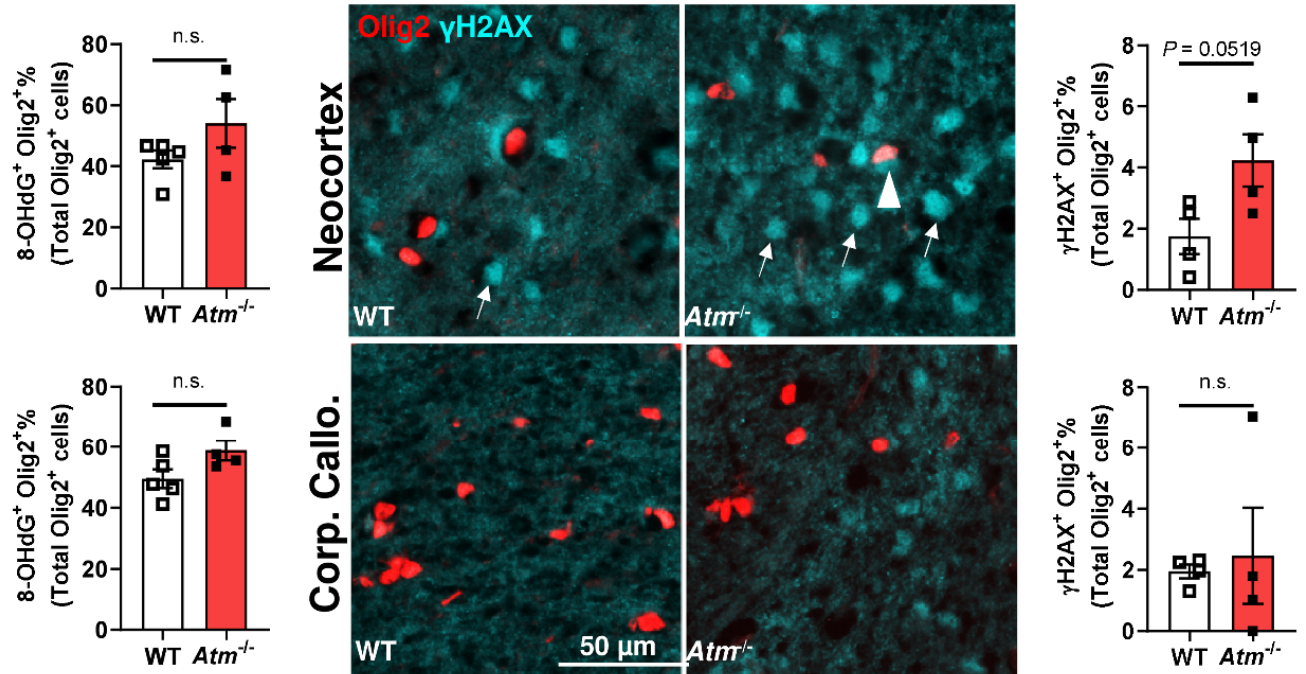

Figure 6. DSB-DNA damage in ATM deficiency and contribution of oxidative stress 
medRxiv preprint doi: https://doi.org/10.1101/2021.01.22.20245217; this version posted January $26,2021$. The copyright holder for this preprint (which was not certified by peer review) is the author/funder, who has granted medRxiv a license to display the preprint in
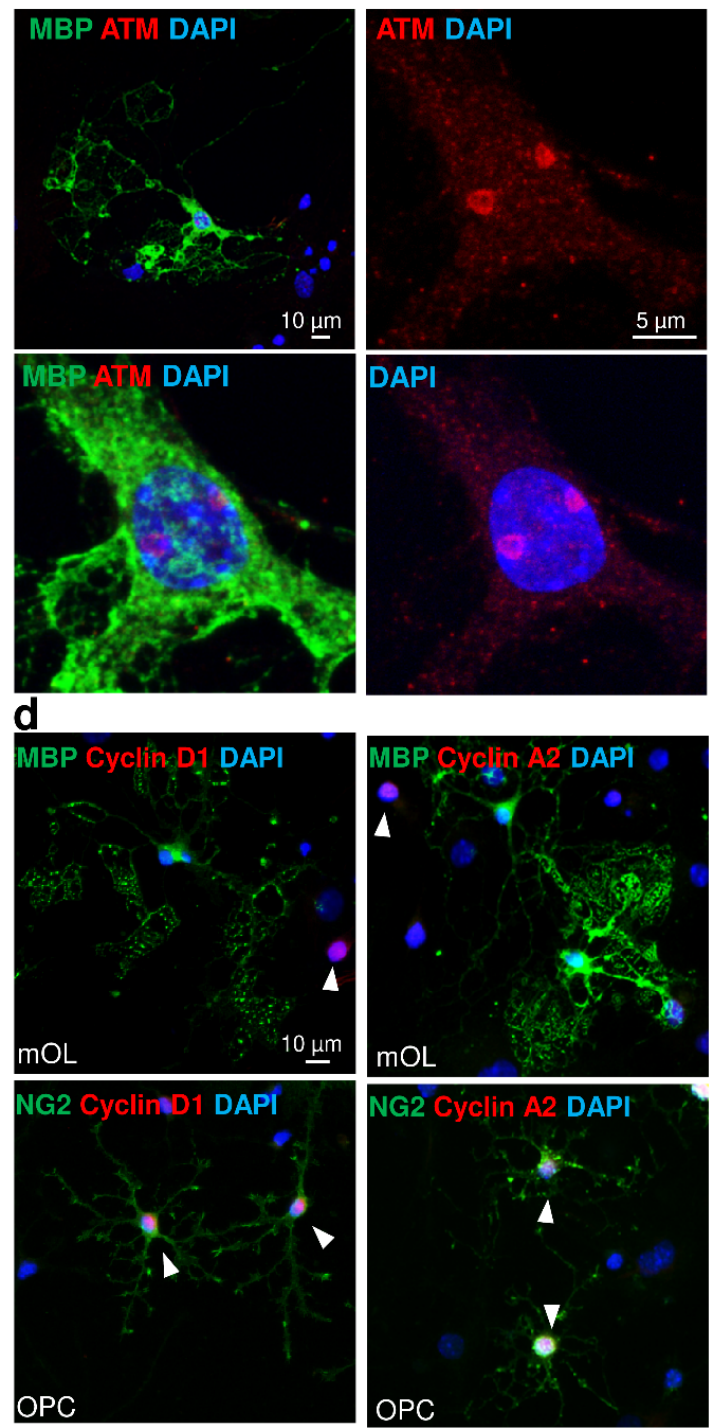

NG2 Cýclin A2 DAPI

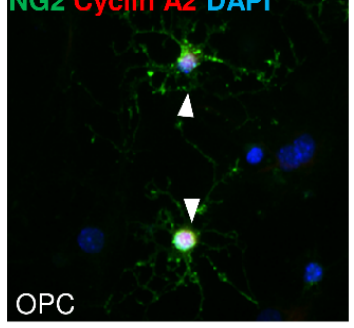

perpetuity.

All hits reserved. No reuse allowed without permission.
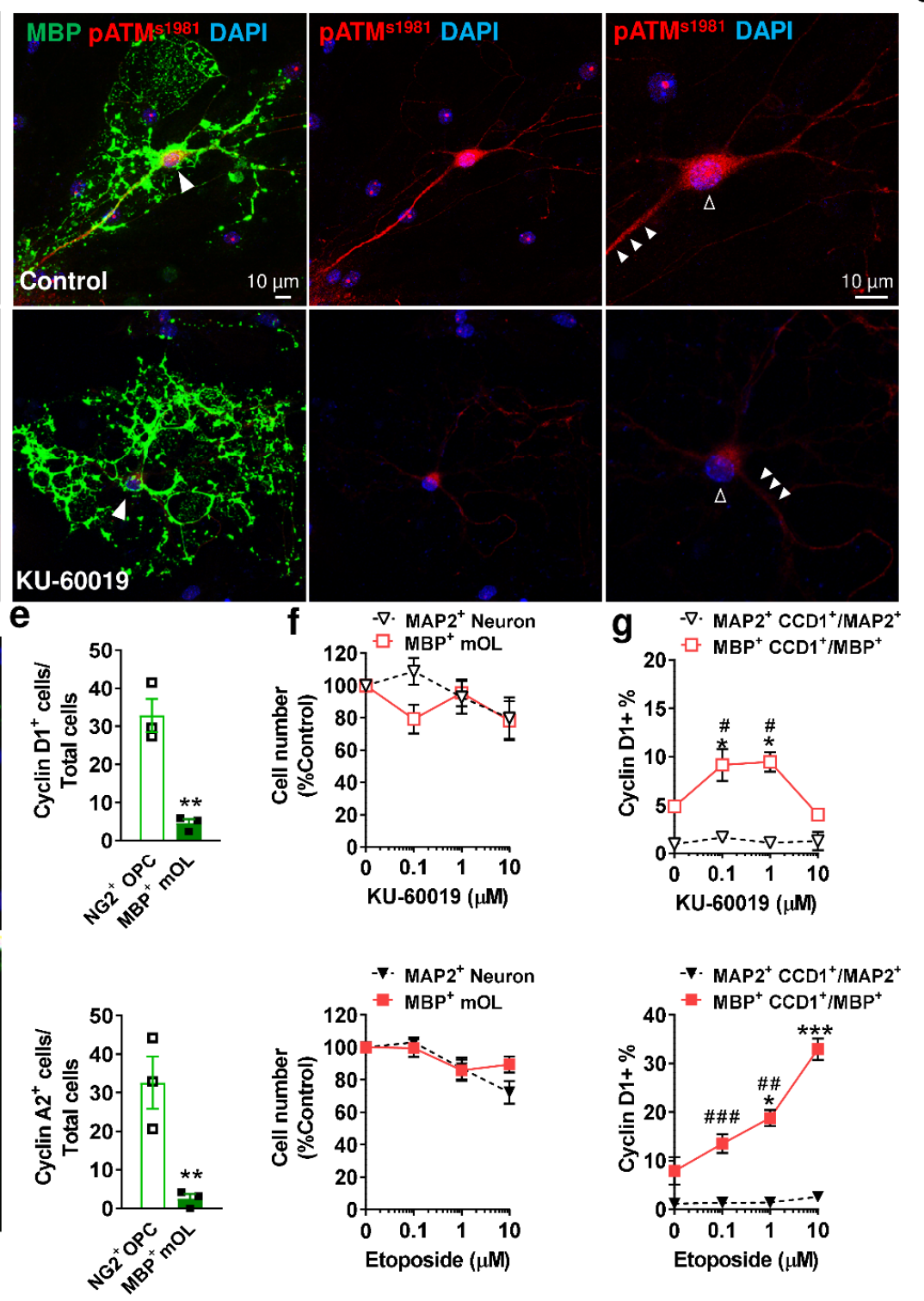

C Control ㅁ $\mathrm{KU}(10 \mu \mathrm{M})$

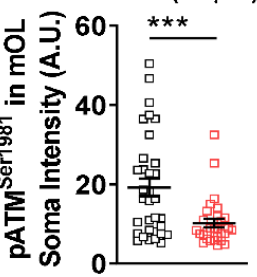

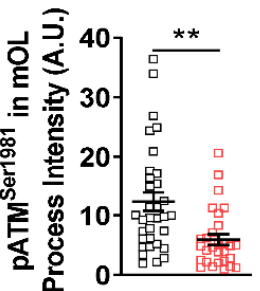

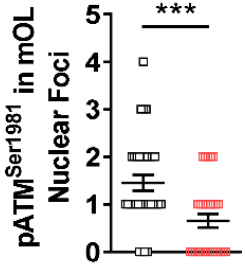

Figure 8. DSBs-induced ATM activation and ATM inhibition triggers aberrant cell cycle re-entry in mOL

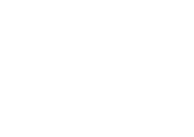


medRxiv preprint doi: https://doi.org/10.1101/2021.01.22.20245217; this version posted January 26, 2021. The copyright holder for this preprint (which was not certified by peer review) is the author/funder, who has granted medRxiv a license to display the preprint in

a

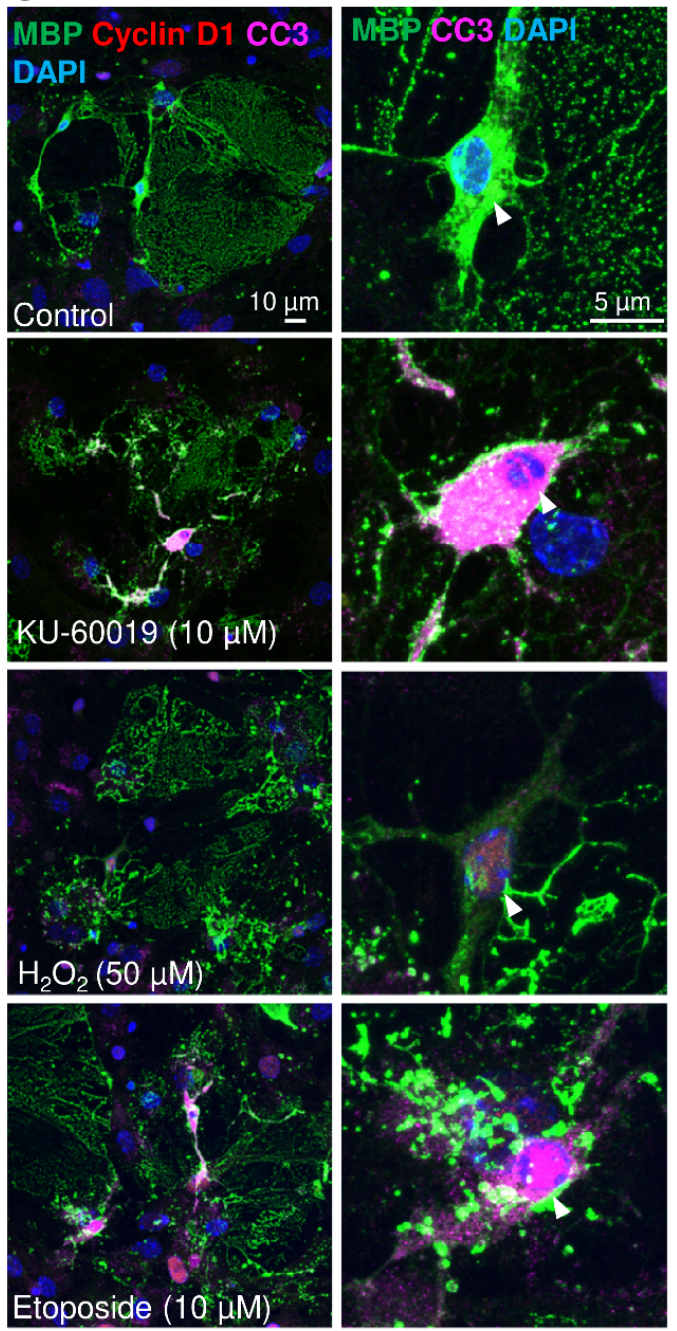
perpetuity.

All rights reserved. No reuse allowed without permission.

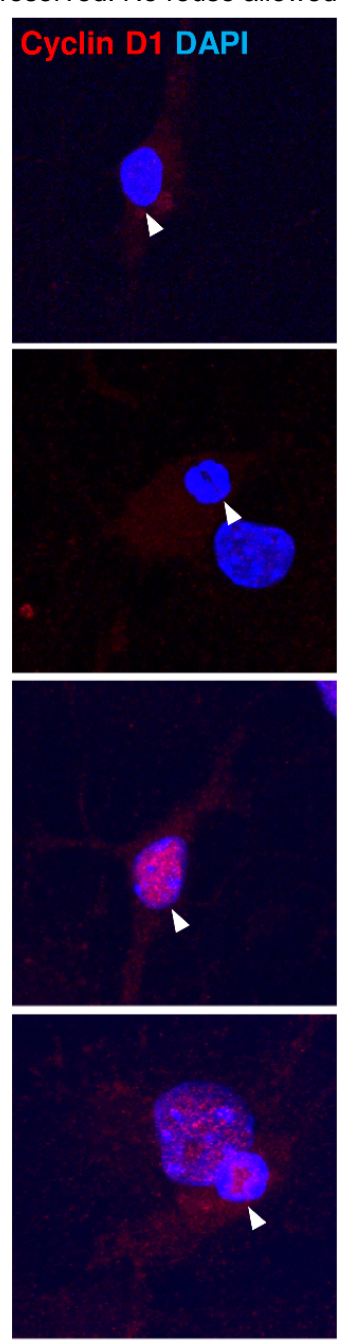

b
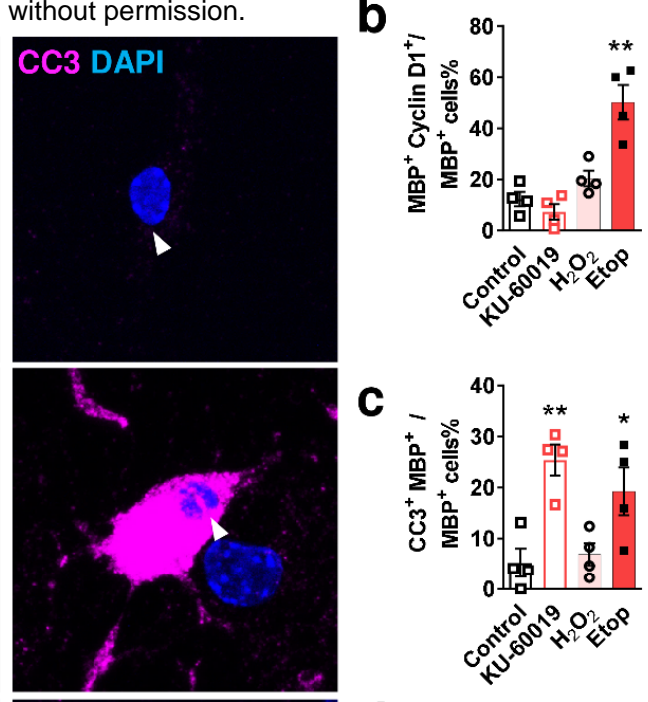

d
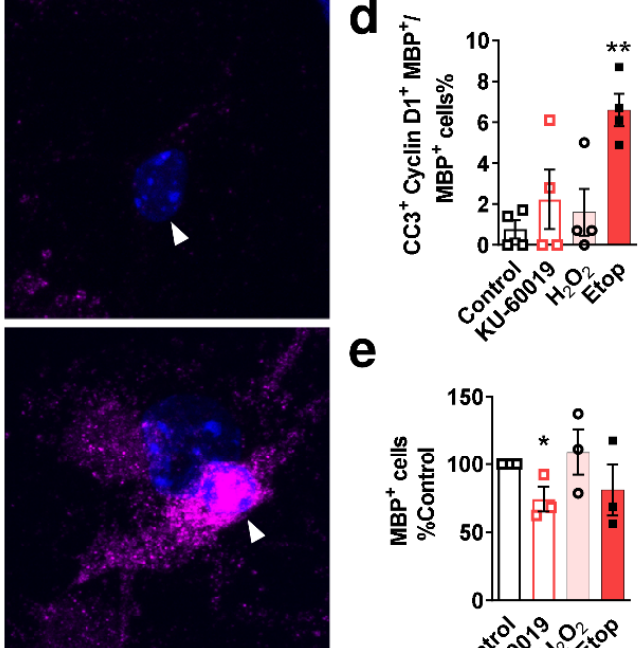

0
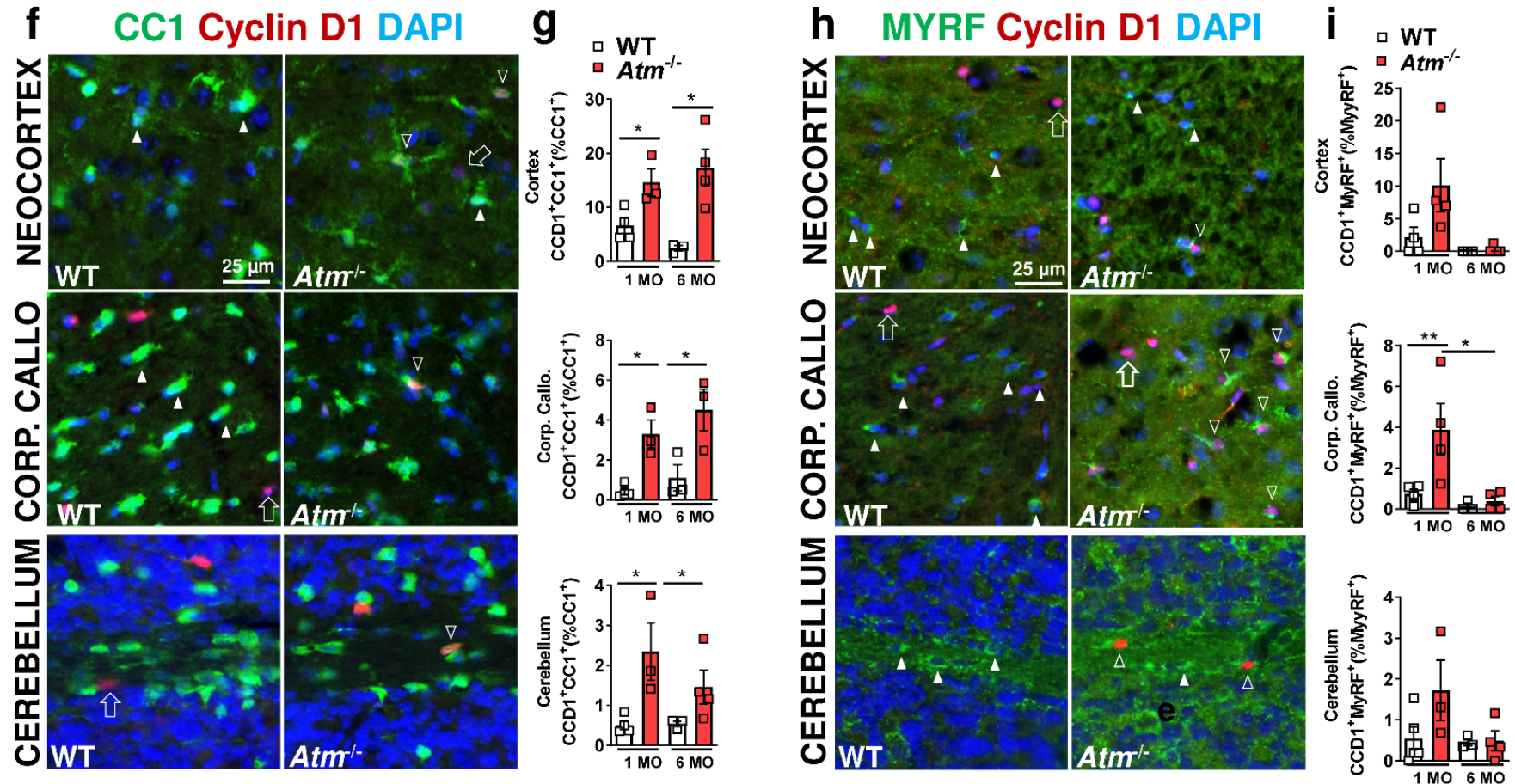

Figure 9. Aberrant cell cycle re-entry is associated with apoptosis in $\mathrm{mOL}$ and mOL loss in vivo 
medRxiv preprint doi: https://doi.org/10.1101/2021.01.22.20245217; this version posted January 26, 2021. The copyright holder for this preprint (which was not certified by peer review) is the author/funder, who has granted medRxiv a license to display the preprint in

perpetuity.
All rights reserved. No reuse allowed without permission.

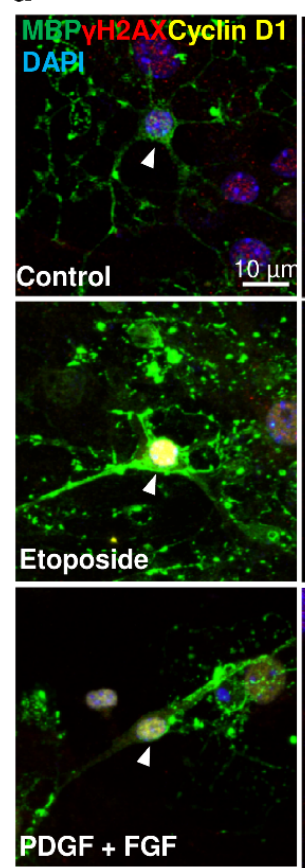

C G1 re-entry C Cyclin D1 d 1/S transitio
Cyclin A2

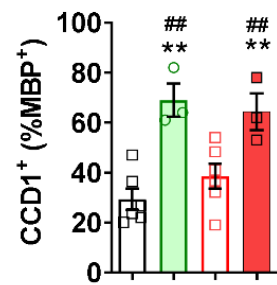

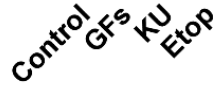

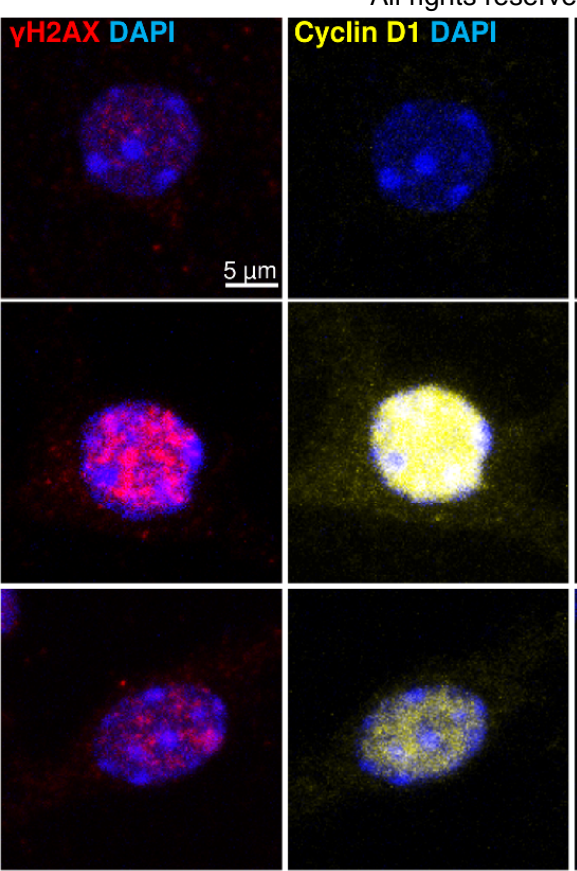

e

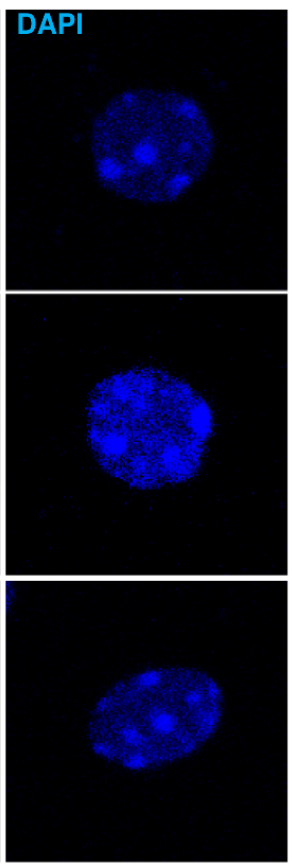

S-phase

dU incorporation

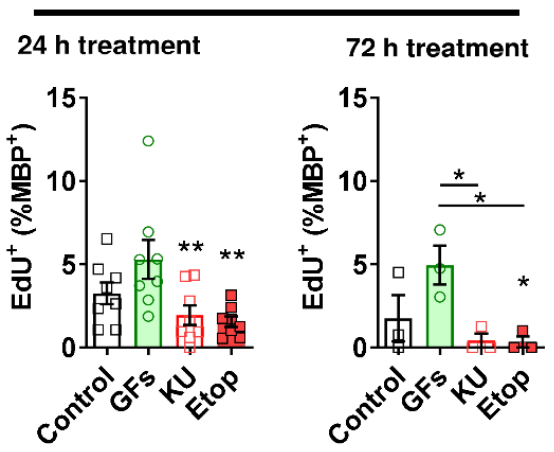

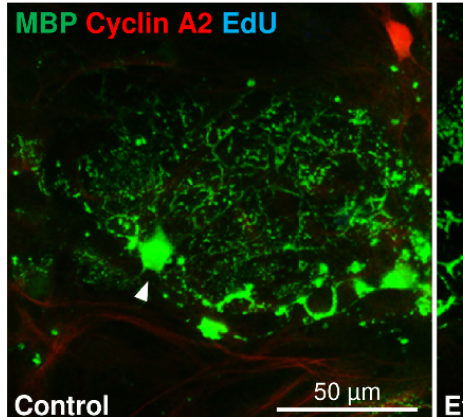

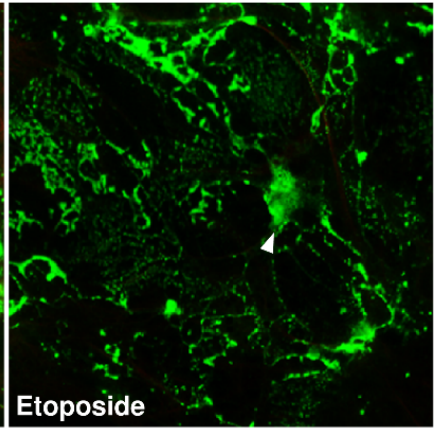

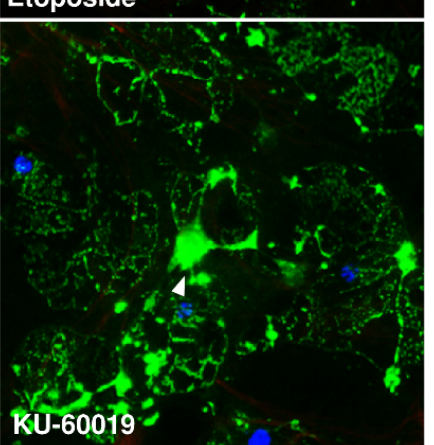

Apoptosis

Cleaved Caspase-3

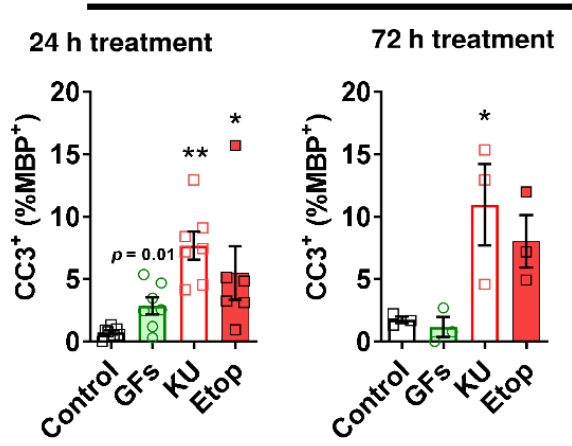

h

ATM inhibition in cycle-related cell death

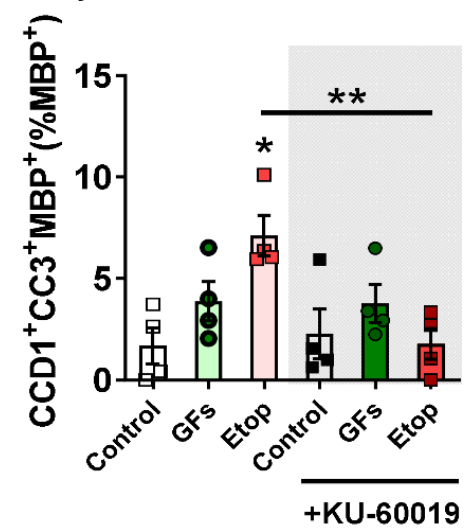

ATM inhibition in cell death

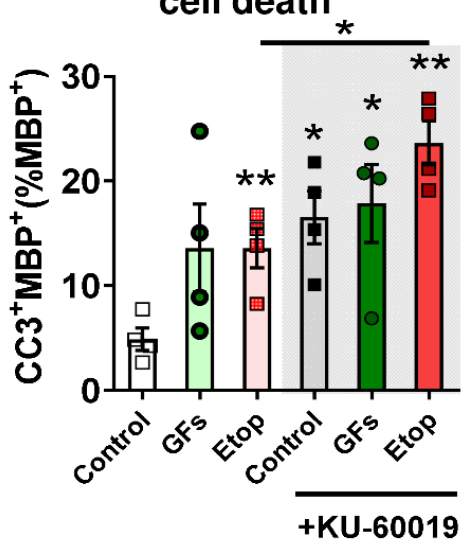

Figure 10. Aberrant cell cycle progression in mOL is DSB specific and controlled by ATM activity 
medRxiv preprint doi: https://doi.org/10.1101/2021.01.22.20245217; this version posted January 26, 2021. The copyright holder for this preprint (which was not certified by peer review) is the author/funder, who has granted medRxiv a license to display the preprint in perpetuity. All rights reserved. No reuse allowed without permission.
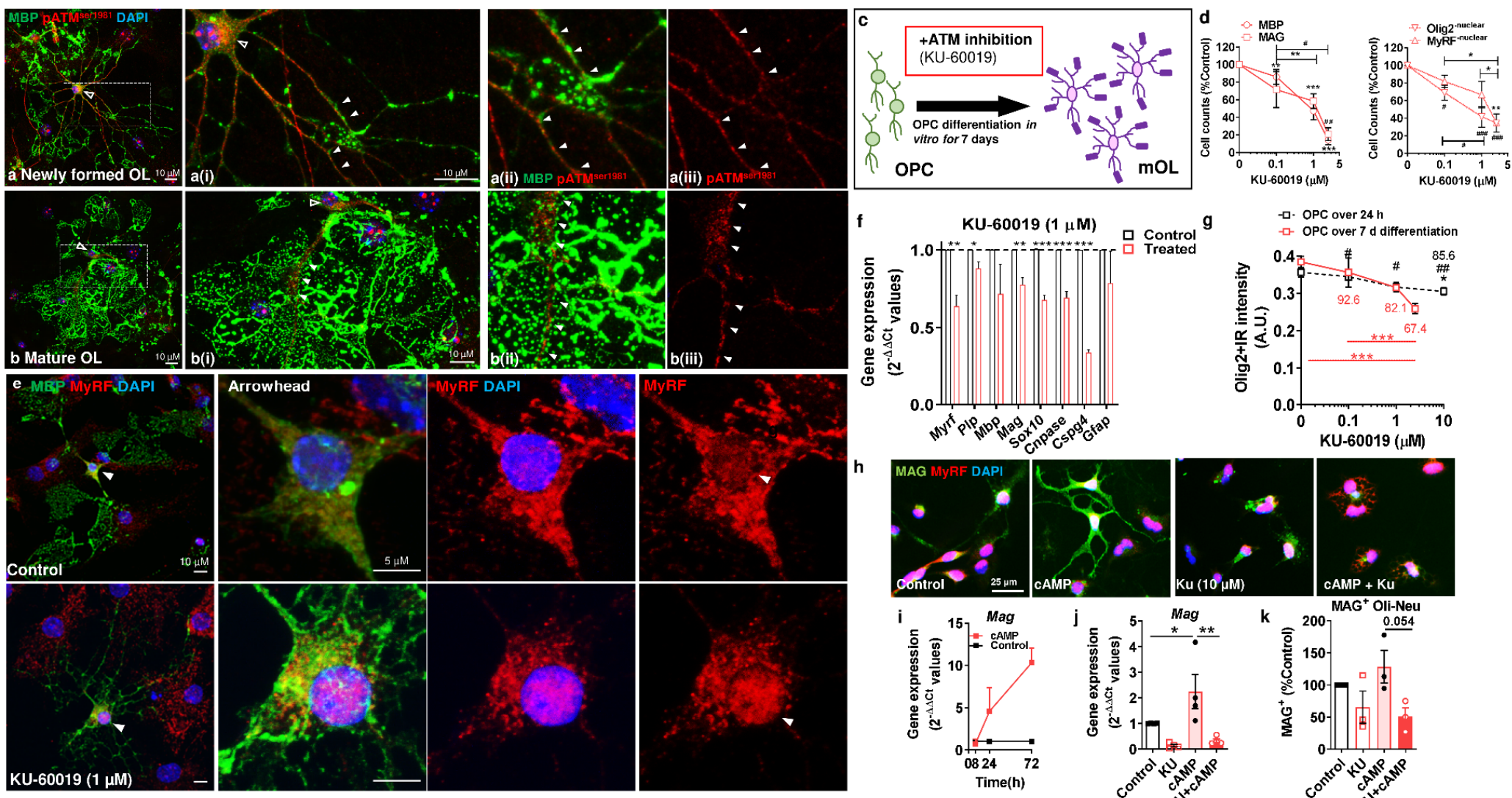

(6)
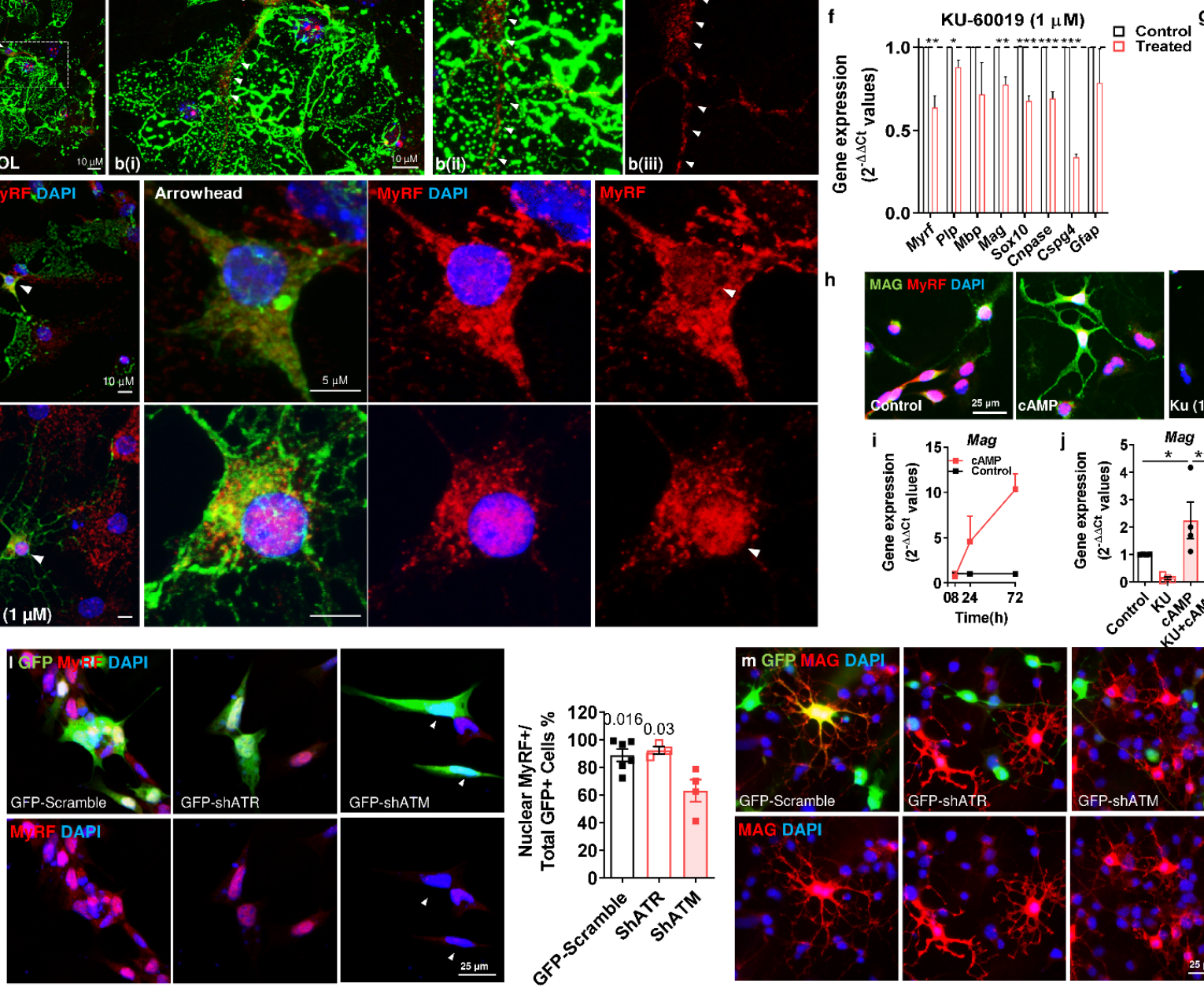

-a. OPC over $24 \mathrm{~h}$
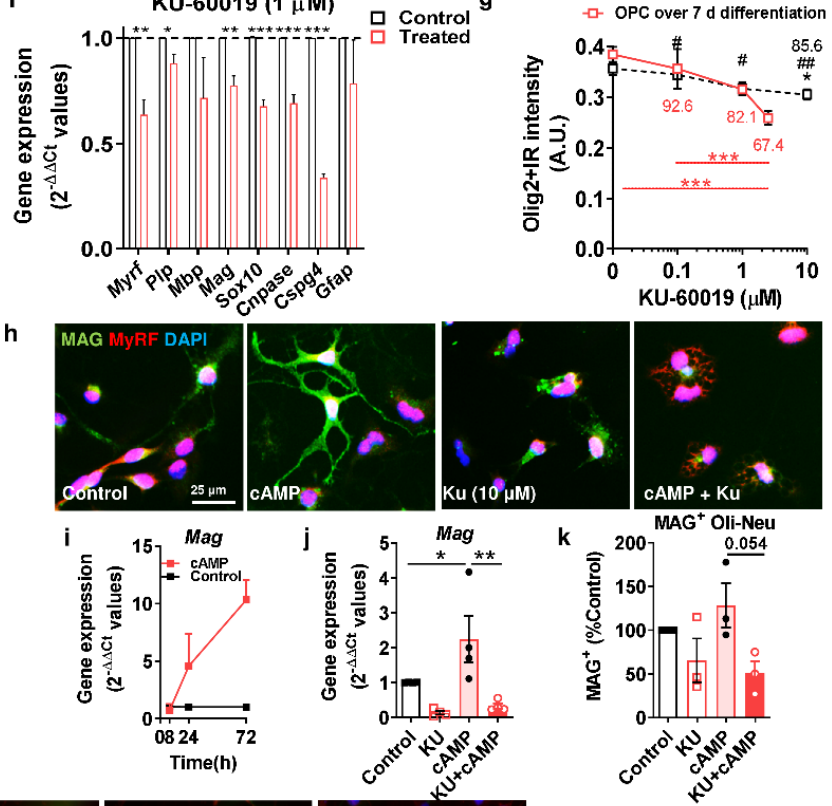

Figure 11. Endogenous ATM activity inhibition attenuates OL differentiation 
medRxiv preprint doi: https://doi.org/10.1101/2021.01.22.20245217; this version posted January 26, 2021. The copyright holder for this preprint (which was not certified by peer review) is the author/funder, who has granted medRxiv a license to display the preprint in

a All rights

breuse allowed without permission.

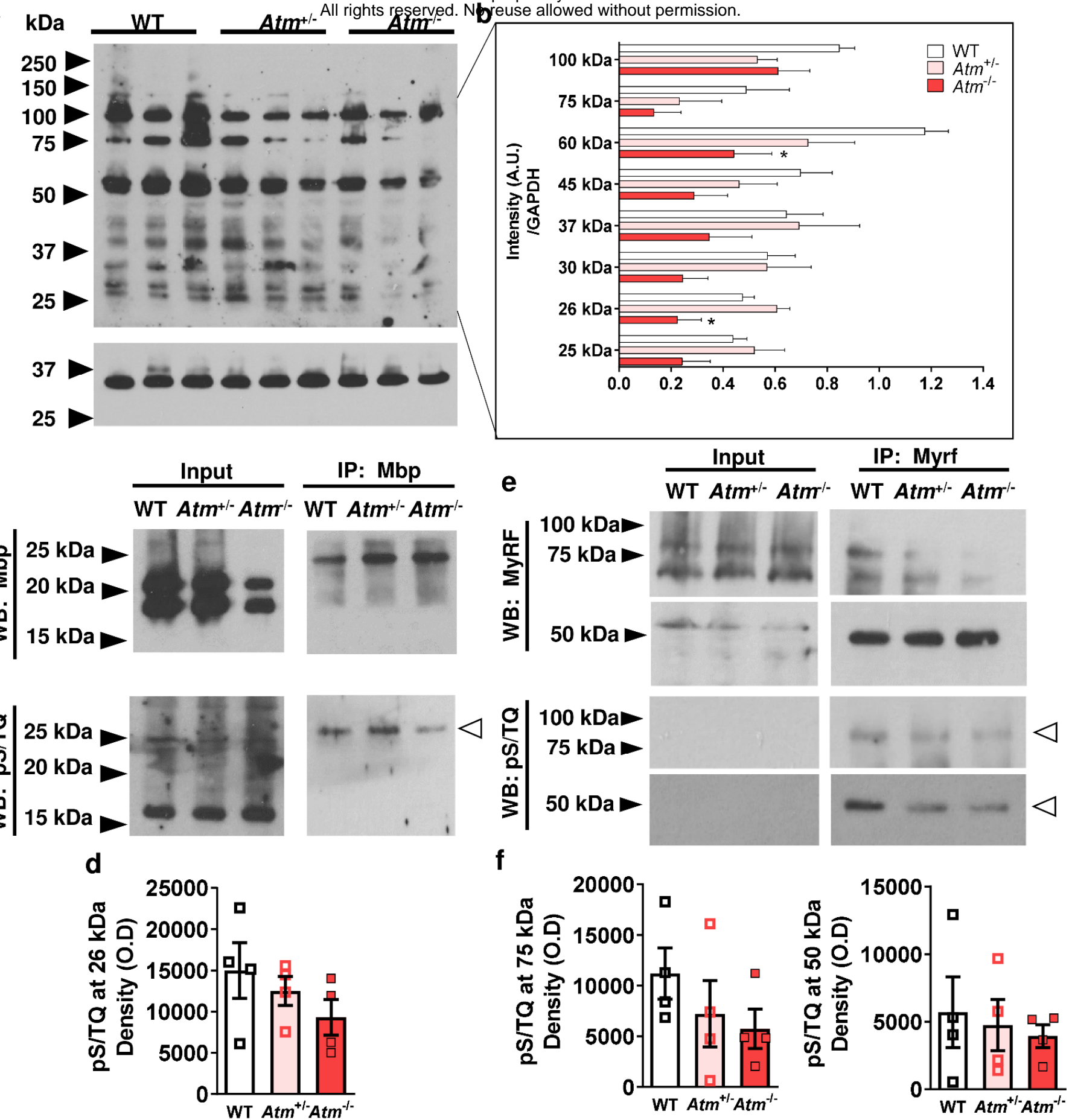

Figure 12. Phosphorylation of $\mathrm{S} / \mathrm{TQ}$ motifs in brain lysate of $\mathrm{Atm}^{-/}$mouse colony 
medRxiv preprint doi: https://doi.org/10.1101/2021.01.22.20245217; this version posted January 26, 2021. The copyright holder for this preprint (which was not certified by peer review) is the author/funder, who has granted medRxiv a license to display the preprint in perpetuity.

a Myelin regulatory factor / Myrf (Mus musculus, NP_001028653.1)

All rights reserved. No reuse allowed without permission.

myelin gene transcriptions

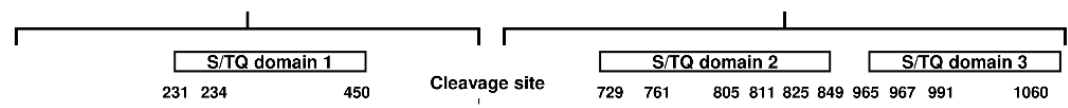

N-

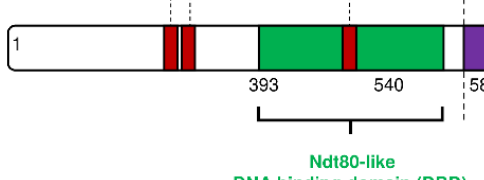

DNA bindin PDB: 5H5P

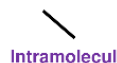

Intramolecular

805811825849965967991

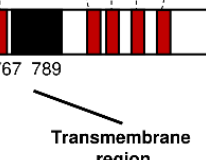

Cytoplasmic localization in endoplasmic reticulum/Golgi
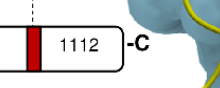

b

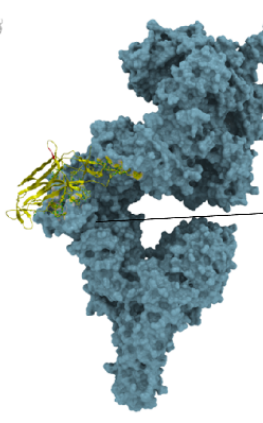

Myrf-DBD PDB: 5H5P x Human ATM PDB:5NPO

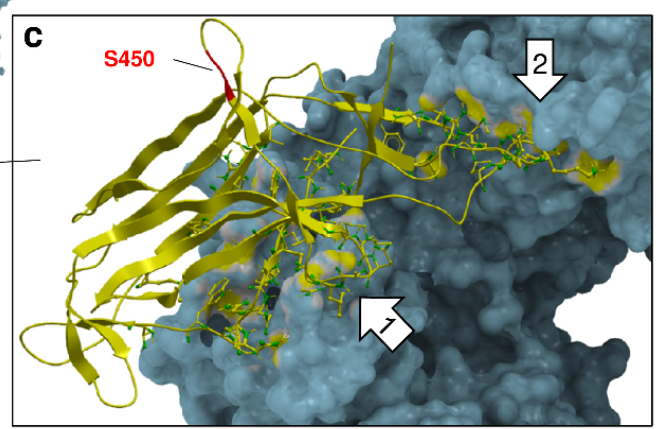

c(i)

S/TQ sites
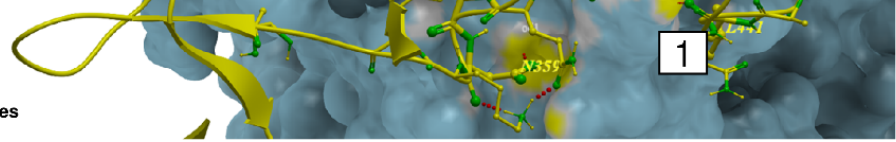

c(ii)

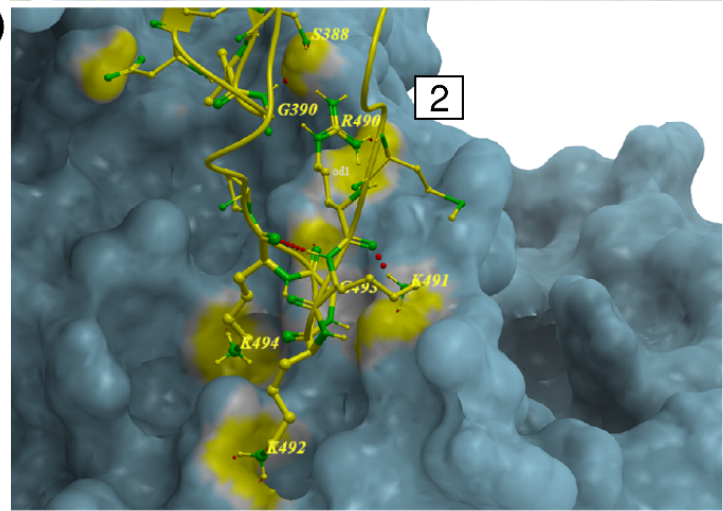

Figure 14. Myelin regulatory factor as a potential phosphorylation target of ATM 
medRxiv preprint doi: https://doi.org/10.1101/2021.01.22.20245217; this version posted January $26,2021$. The copyright holder for this preprint (which was not certified by peer review) is the author/funder, who has granted medRxiv a license to display the preprint in

All rights reserved. No reuse allowed without permission.

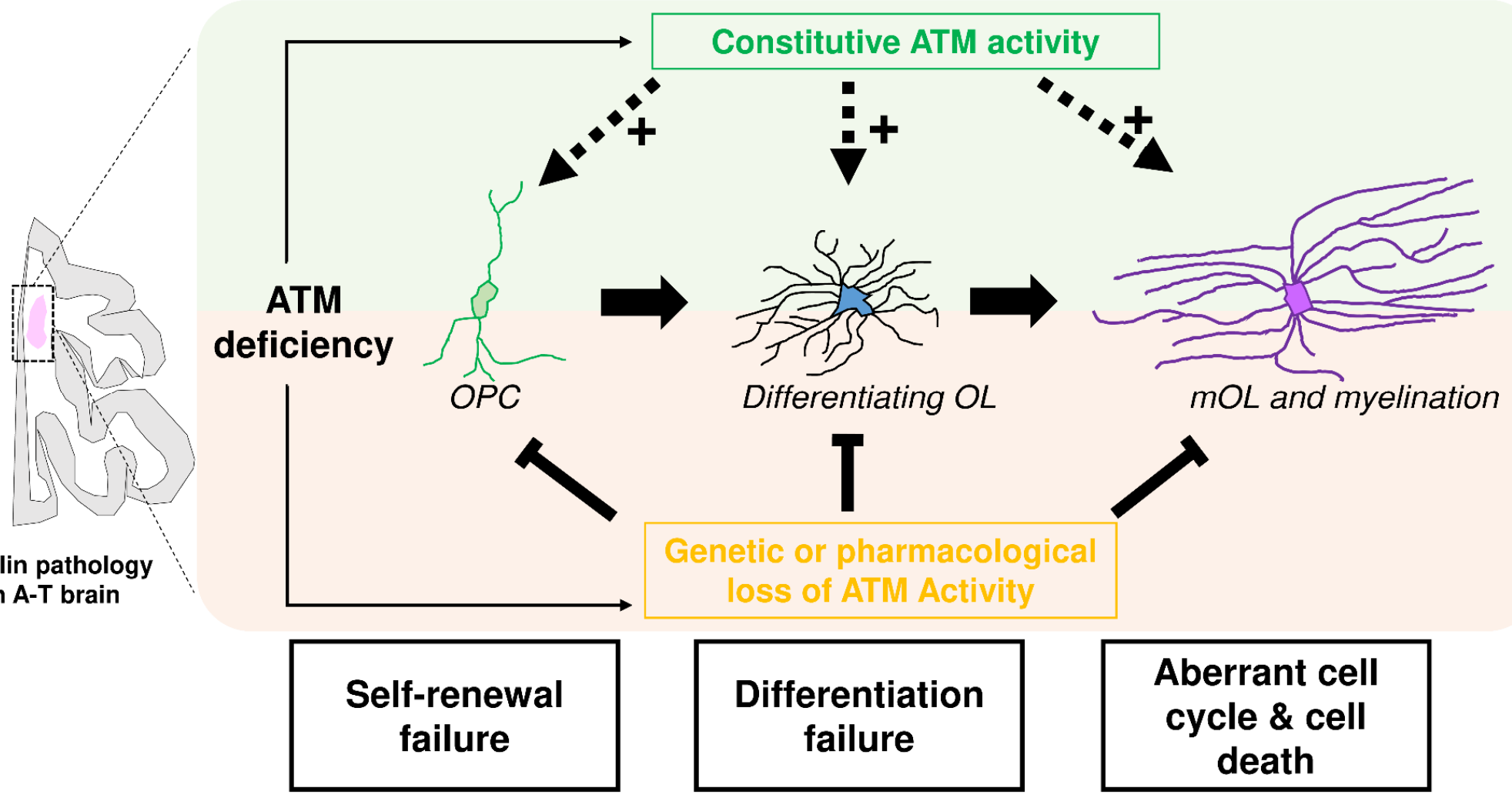

Figure 16. Multifaceted functions of ATM in OL life cycle 
medRxiv preprint doi: https://doi.org/10.1101/2021.01.22.20245217; this version posted January 26, 2021. The copyright holder for this preprint (which was not certified by peer review) is the author/funder, who has granted medRxiv a license to display the preprint in
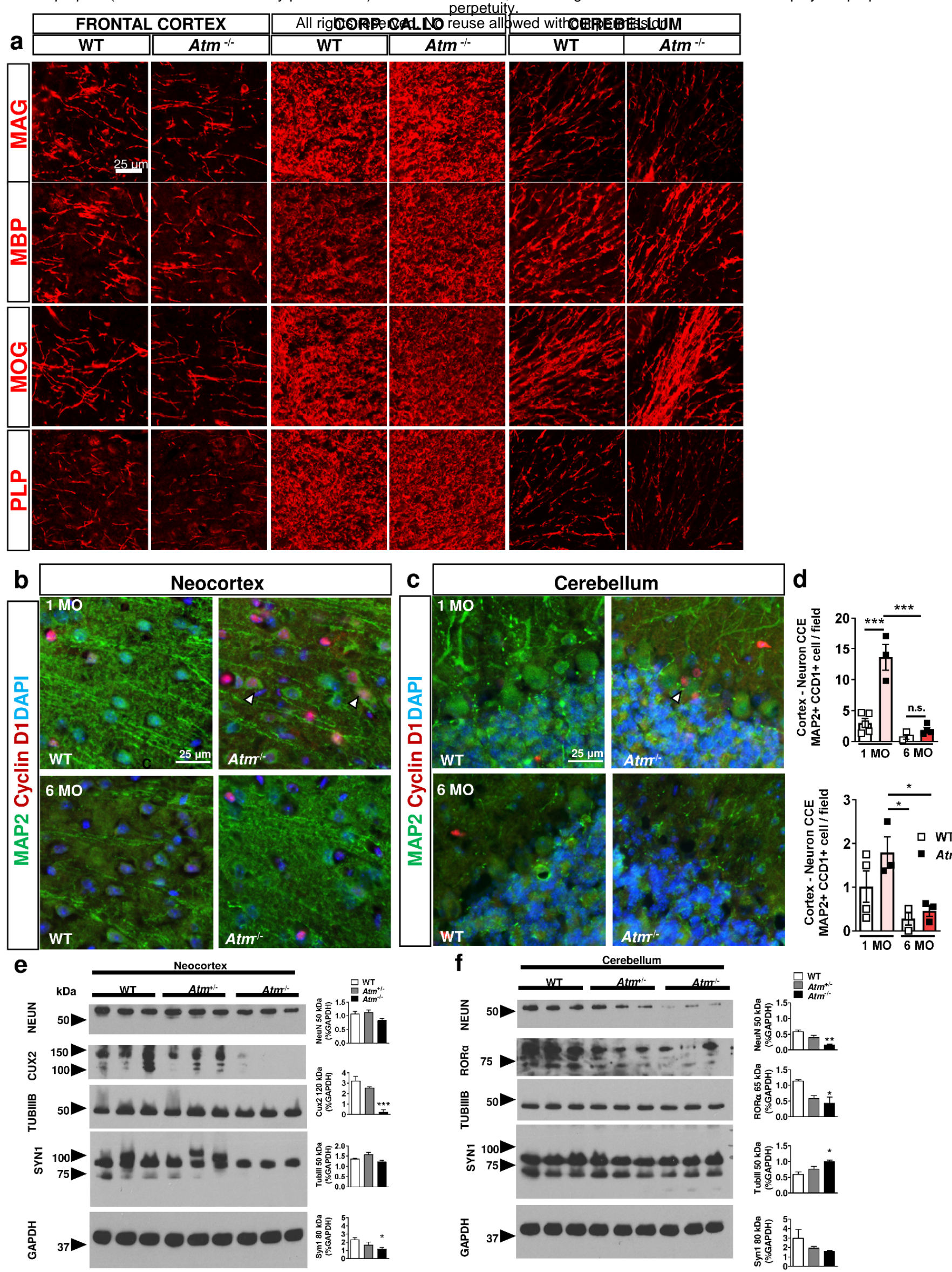

Figure S1. Age- and genotype-associated neuropathology in $\mathrm{Atm}^{--}$mice 
medRxiv preprint doi: https://doi.org/10.1101/2021.01.22.20245217; this version posted January 26, 2021. The copyright holder for this preprint (which was not certified by peer review) is the author/funder, who has granted medRxiv a license to display the preprint in perpetuity.

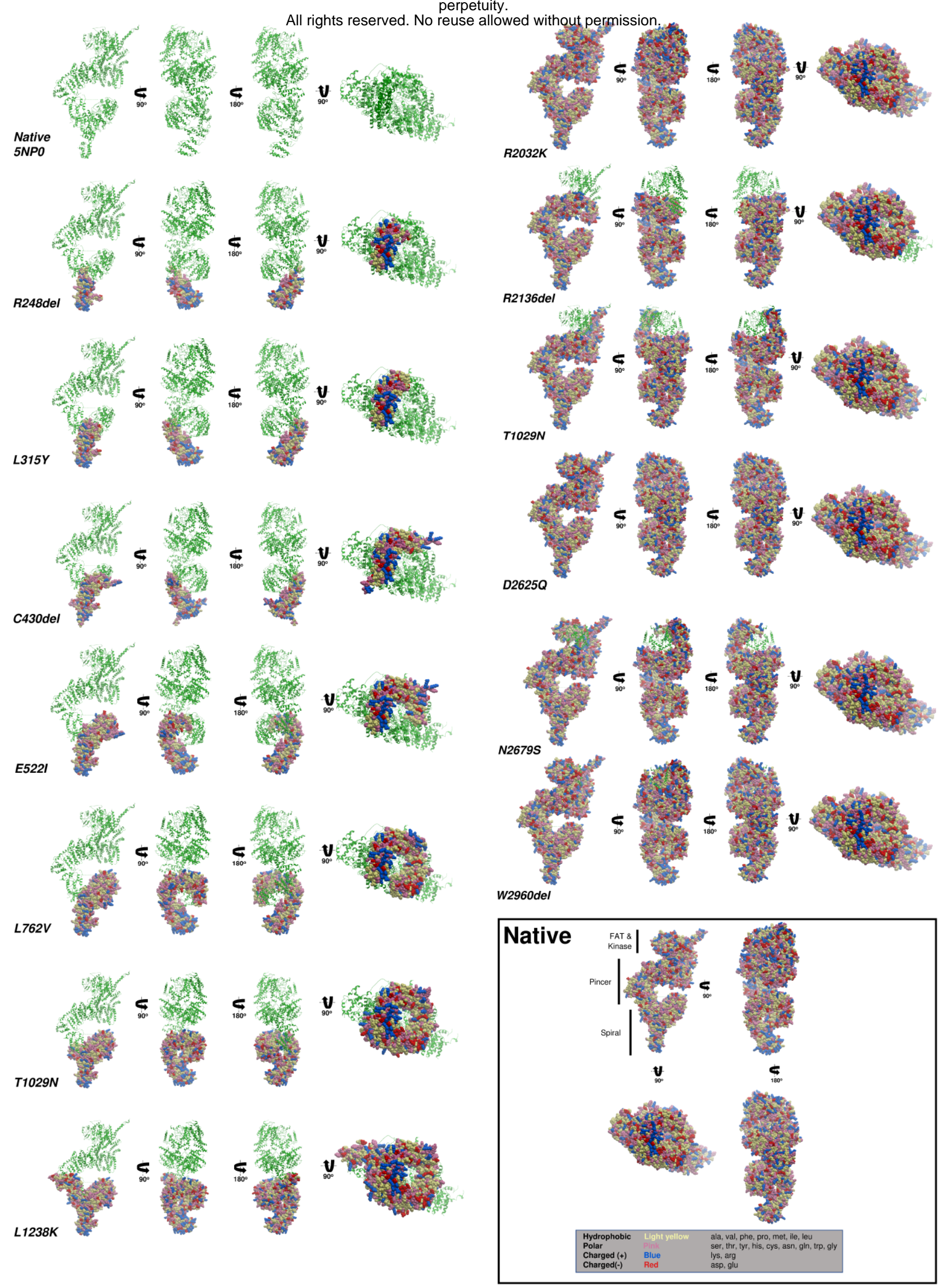

Figure S3. Structural modeling of clinical ATM variants based on human ATM template PDB:5NP0 